Portland State University

PDXScholar

$1-1-2011$

\title{
A Study of Soil Organic Matter and Its Controlling Factors in Portland, Oregon
}

Megan Dillon

Portland State University

Follow this and additional works at: https://pdxscholar.library.pdx.edu/open_access_etds

Let us know how access to this document benefits you.

\section{Recommended Citation}

Dillon, Megan, "A Study of Soil Organic Matter and Its Controlling Factors in Portland, Oregon" (2011). Dissertations and Theses. Paper 155.

https://doi.org/10.15760/etd.155

This Thesis is brought to you for free and open access. It has been accepted for inclusion in Dissertations and Theses by an authorized administrator of PDXScholar. Please contact us if we can make this document more accessible: pdxscholar@pdx.edu. 


\title{
A Study of Soil Organic Matter and Its Controlling Factors \\ in Portland, Oregon
}

\author{
by
}

\section{Megan Dillon}

A thesis submitted in partial fulfillment of the requirements for the degree of

\section{Master of Science \\ in \\ Biology}

Thesis Committee:

Todd Rosenstiel, Chair

Sarah Eppley

Radu Popa

Martin Lafrenz

\section{Portland State University}




\begin{abstract}
Traditionally, local above- and below-ground plant and microbial communities, temperature and precipitation, topography and texture and composition of parent material have been thought to govern the soil processes that lead to soil organic matter accumulation over decades or centuries. Soil organic matter is a substantial global reservoir of carbon and disturbance of equilibrated soils often leads to efflux of significant quantities of $\mathrm{CO}_{2}$. Anthropogenic influences shift the inputs, disturb the structure and alter the biochemistry of soil, profoundly disrupting soil-forming processes. Urbanization leads to soil organic matter equilibria that are different from those in naturally forming soils. Measurement of soil organic matter in diverse cities suggests that they differ in their capacity to accumulate soil organic matter. Here I quantify soil organic matter and examine the limitations of its accumulation within cities by comparing differences in soil organic matter and natural and anthropogenic characteristics at the neighborhood, city and regional scales in Portland, Oregon to that in the Pacific Northwest. I found that each Portland neighborhood has distinct urban characteristics and tree and shrub community composition, but soil organic matter content is indistinguishable among them. Across Portland, neither vegetation structure nor urban factors appear to directly influence soil organic matter content. Rather, microbial biomass, bulk density and total nitrogen appear to be important factors controlling soil organic matter content in Portland. The amount of soil organic matter stored in Portland's soils is statistically indistinguishable from Pacific Northwest soils, in contrast to other temperate cities.
\end{abstract}




\section{Acknowledgements}

I am very grateful for the meaningful concepts and direction imparted by Drs. Todd Rosenstiel and Vivek Shandas; to Drs. Sarah Eppley, Radu Popa and Martin

Lafrenz and to Colin Krusor for encouraging me to accurately and precisely communicate my work; and for the many hours that fellow students Paula Hood, Micheal Krochta, Andrea Melnychenko, Hannah Prather and Hayley Darby donated to the success of this research. 


\section{Table of Contents}

Abstract

Acknowledgements

List of Tables

List of Figures

Introduction

Methods

Results

Discussion

Tables

Figures

52

References

65

Appendix A. Genera Recorded at Each Site

77

Appendix B. Coordinates of Each Site 


\section{List of Tables}

Table 1. Summary of Vegetation Statistics for Downtown 42

Table 2. Summary of Vegetation Statistics for Lloyd District 42

Table 3. Summary of Vegetation Statistics for Gateway 43

Table 4. Summary of Vegetation Statistics for Lents 43

Table 5. Summary of Vegetation Statistics for Portland 44

Table 6. Summary Soil Statistics for Downtown 44

Table 7. Summary Soil Statistics for Lloyd District 45

Table 8. Summary Soil Statistics for Gateway 45

Table 9. Summary Soil Statistics for Lents 45

Table 10. Summary of Soil Statistics for Portland 46

Table 11. Summary of Urban Statistics for Downtown 46

Table 12. Summary of Urban Statistics for Lloyd District 46

Table 13. Summary of Urban Statistics for Gateway 47

Table 14. Summary of Urban Statistics for Lents 47

Table 15. Summary of Urban Statistics for Portland 48

Table 16. Principle Components Loadings of Urban Variables for Portland 48

Table 17. Summary of Regression Analysis for Downtown 49

Table 18. Summary of Regression Analysis for Lloyd District 49

Table 19. Summary of Regression Analysis for Gateway 50

Table 20. Summary of Regression Analysis for Lents $\quad 50$

Table 21. Summary of Regression Analysis for Portland 50

Table 22. Publications Used to Compare Portland to Pacific Northwest Soil Organic Carbon 51

Table 23. Comparison of Pacific Northwest Forest Soils to Portland Soils 


\section{List of Figures}

Figure 1. Sampling Sites 52

Figure 2. Differences in Vegetation Structure Among EcoDistricts

Figure 3. ANOSIM of Bray-Curtis Distance Among EcoDistricts

Figure 4. Differences in Soil Properties Among EcoDistricts 55

Figure 5. Soil Organic Matter Among EcoDistricts 56

Figure 6. Map of Soil Organic Matter in Portland 57

Figure 7. Distribution of Soil Organic Matter in Portland 58

Figure 8. Differences in Urban Characteristics Among EcoDistricts

Figure 9. Expected vs. Observed Soil Organic Matter Values for Portland

Figure 10. Soil Organic Matter in Portland and the Pacific Northwest

Figure 11. Soil Organic Matter Varies by Biome

Figure 12. Soil Organic Matter in Temperate Cities

Figure 13. Changes in Soil Organic Matter with Urbanization in Temperate Cities

Figure 14. Changes in Soil Organic Matter with Urbanization by Biome 


\section{Introduction}

Soils are unique and extraordinarily complex systems that serve as a vital hub for the transformation and redistribution of the myriad chemical constituents of life. The canonical source-and-sink duality of ecological systems is particularly apparent in the biogeochemistry of soils. Almost all organic detritus of terrestrial origin is decomposed on the vast surfaces of soil particles or within the intervening interstices (Swift et al., 1979). The products of this decomposition are either sequestered in refractory form or rendered into trophically available forms that can be assimilated by soil organisms or exported from the soil as a gas or aqueous solutes (Sollins et al., 1996). The enormous throughput of these processes is crucial to the global biogeochemical cycling of carbon, nitrogen, oxygen, sulfur and many other elements.

The role of soils in the global carbon cycle is of particular interest, due in part to the fact that a vast quantity of carbon resides in the world's soils. Concerns have been voiced that this reservoir will contribute to atmospheric carbon (positive feedback) under progressively warming climate conditions (Jones et al., 2003; Lenton \& Huntingford, 2003; Kirschbaum, 2000). Liberation of carbon from soils could amplify and accelerate any gradual positive change in global temperatures. The metabolic rates $\left(\mathrm{Q}_{10}\right.$ approximately 2-4, depending on the recalcitrance of the substrate) of detritivorous soil flora and fauna increase dramatically with increases in soil temperature (Conant et al., 2008) and this increase in $\mathrm{CO}_{2}$ evolution from soils could outpace the marginal increase in $\mathrm{CO}_{2}$ fixation by plants at the global scale (Luo et al., 2004). 
Soils, however, are remarkably diverse, and the contributions of a particular soil type to biogeochemical cycles, including the carbon cycle, are governed by its chemical and biological composition and its physical structure. The structural organization of terrestrial soils is observable as strata called horizons. The numbers, thicknesses and types of horizons in any given soil depend on local climate, topography, biological factors, the composition of the parent material, the age of the soil, and the degree and frequency of physical disturbance (Jenny, 1946). Soil carbon is non-uniformly distributed throughout soil horizons; organic carbon mostly accumulates in the surface horizons of mineral soils (Batjes, 1996).

Four soil processes describe the movement of carbon through the soil system: addition, loss, translocation and transformation (Brady \& Weil, 2008). Addition denotes the deposition of new carbon, mostly as plant and animal detritus, both above- and below-ground. Carbon is lost from soil via leaching of carbonates and dissolved organic carbon into ground and surface water (Laudon et al., 2011), a common phenomenon in northern latitude ecosystems. Translocation is the movement of carbon laterally, vertically or between horizons. Transformation refers to chemical changes, including those involved in respiration and humification. Widespread increases in the rate of transformation of soil carbon into $\mathrm{CO}_{2}$ is of great concern to global change scientists (Davidson et al., 2000).

Soil organic matter is a confusion of complex molecules derived from partially decomposed terrestrial organisms. The $\mathrm{C}: \mathrm{N}$ ratio of soil organic matter can range from 8:1 to 15:1. To understand how increases in temperature and atmospheric $\mathrm{CO}_{2}$ concentration might influence soil carbon dynamics, it is necessary to consider the 
various pools of soil organic matter and the individual dynamics of each pool. Although the carbon-containing molecules within a soil range from extreme chemical simplicity to staggering complexity, they are often designated as belonging to one of three pools differing in cycling time and lability: fast, slow and passive (Parton et al., 1987). Fastturnover carbon describes simple, bioavailable compounds like sugars that are rapidly transformed. Slow-turnover carbon describes more complex organic molecules, like lignin, that are significantly more persistent and recalcitrant to biotic and abiotic degradation. Passive carbon compounds, such as clay-protected humic acids, are extremely long-lived, refractory and may persist in some soils for millennia (Paustian et al., 1992).

Soil organic matter comprises a class of soil carbon that is vulnerable to transformation in response to global change (Pendall et al., 2004; Davidson \& Janssens, 2006). The effects of increasing global temperatures and atmospheric $\mathrm{CO}_{2}$ concentrations have generally been predicted to influence soil carbon reserves by three distinct, but interrelated mechanisms. First, the metabolic rates of detritivorous soil microorganisms increase dramatically as soil temperature rises (Chen \& Tian, 2005; Davidson \& Janssens, 2006). Second, deposition of simple, bioavailable carbon compounds by plant roots into deep soil horizons, termed soil priming, may increase with increasing $\mathrm{CO}_{2}$ and precipitation. The increased deposition of simple carbon compounds tends to cause microbial decomposition of recalcitrant substrates that would otherwise not readily be transformed into $\mathrm{CO}_{2}$ (Guenet et al., 2010). Finally, soils tend to become nitrogen depleted over time under conditions of elevated temperature and atmospheric $\mathrm{CO}_{2}$. This progressive nitrogen limitation may increase the metabolism of passive carbon 
compounds by soil fungi (Carreiro et al., 2000; Waldrop \& Zak, 2006), consequently increasing $\mathrm{CO}_{2}$ production.

Predictions of the changes that may occur in soil organic matter under the conditions likely to attend global climate change vary widely. Not only are responses predicted to vary by ecosystem, but, also, different carbon reservoirs will respond to temperature differently, and, of course, environmental attributes and the availability of soil carbon (and nitrogen) substrates affect each other (Davidson \& Janssens, 2006). Such entanglement has been confirmed by field and laboratory research as well as modeling studies. In tropical forests, increasing temperatures have been observed to decrease soil organic matter at a rate of $-8 \mathrm{Mg} \mathrm{C} /{ }^{\circ} \mathrm{C}$, offsetting gains in net primary productivity (Raich et al., 2006). Similarly, in arctic soils, $\mathrm{CO}_{2}$ emission from soils is associated with increasing temperatures (Parsons et al., 2004). Experimental warming of identical soil subsamples by Hartley and Ineson (2008) revealed that decomposition rate increased over time, supporting the hypothesis that relatively recalcitrant carbon pools are more sensitive to rising temperatures (Hartley \& Ineson, 2008). Similar experiments, however, have demonstrated that depth and incubation time affected decomposition rate while temperature sensitivity was not affected by incubation time, implying that soil organic matter pools would respond to increasing temperatures uniformly (Fang et al., 2005). In stark contrast, after conducting a meta-analysis of global decomposition rates across a gradient of mean annual temperature, Giardina and Ryan (2000) refuted the hypothesis that soil organic matter decomposition increases with rising temperatures, citing similar rates across different latitudes. Models calculated by Jones et al. (2003) indicate that the effects of temperature increases on soil organic matter decomposition are 
likely to overwhelm gains in net primary productivity, but that the relationship between the two is crucial to determining whether the terrestrial biosphere becomes a carbon source or remains a carbon sink over the course of the next century.

Elevated $\mathrm{CO}_{2}$ concentration is predicted to increase the net primary productivity of plants, possibly to such an extent as to balance losses of soil carbon, but nitrogen availability has been observed to limit such a response. For example, in a long-term study, Reich et al. (2006) saw early gains in plant biomass under elevated $\mathrm{CO}_{2}$ in fertilized and unfertilized plots, but only fertilized plants continued to increase in biomass after four to six years. The greatest gains in net primary productivity appear to be in root biomass, in both number and length (Zak et al., 1993; Pregitzer et al., 2000). Zak et al. (1993) observed increased root biomass in nitrogen limited, elevated $\mathrm{CO}_{2}$ treatments, and found greater labile carbon and microbial biomass in the rhizosphere of elevated $\mathrm{CO}_{2}-$ grown plants. In their P. tremuloides study, Pregitzer et al. (2000) only observed increased root biomass under elevated $\mathrm{CO}_{2}$ with nitrogen fertilization, but found that soil respiration was significantly greater with elevated $\mathrm{CO}_{2}$ and with high nitrogen treatments. These conflicting results are resolved to some extent by a meta-analysis performed by Zak et al. (2000). Their results indicate that while elevated $\mathrm{CO}_{2}$ definitely increases soil and microbial respiration, effects of nitrogen vary widely with plant species (Zak et al., 2000). Regardless of the magnitude or longevity of increased primary productivity with elevated atmospheric $\mathrm{CO}_{2}$, Heimann and Reichstein (2008) point out that increased net primary productivity, itself, can increase soil respiration via progressive nitrogen limitation and the priming effect (Heimann \& Reichstein, 2008). 
Field-scale experiments that manipulate ecosystem-scale $\mathrm{CO}_{2}$ and temperature simultaneously are generally lacking, primarily due to technical difficulties of doing both simultaneously. Results from the few such studies that report combined elevated $\mathrm{CO}_{2}$ and elevated temperature include increased root turnover without interaction (Wan et al., 2004), increased fine root biomass in some species but not others (King et al., 1996) and reduced root biomass (Soussana et al., 1996). In their literature review, Pendall et al. conclude that the interactive effects of elevated $\mathrm{CO}_{2}$ and elevated temperature are likely to enhance soil carbon decomposition. In support of that hypothesis, a model generated by $\mathrm{Lu}$ et al. (2009) indicates that rising levels of atmospheric $\mathrm{CO}_{2}$ and global temperatures are unequally increasing both plant carbon fixation and soil organic matter decomposition, resulting in the Mongolian plateau becoming a $\mathrm{CO}_{2}$ source whereas it was previously a sink. Given the inherent uncertainties in the system, and despite good preliminary observations, the ability to quantify the changes that may occur in soil organic matter with global climate change remains elusive (Zak et al., 2000). A better understanding of the factors influencing soil organic matter formation in soils (across a wide range of biomes) in response to simulated global change would improve our predicative capabilities.

Urban ecosystems offer an experimental system to examine the simultaneous impacts of temperature and $\mathrm{CO}_{2}$ on soil organic matter dynamics. The urban heat island effect increases temperatures via decreased albedo, reduced vegetation, increased latent heat in urban infrastructure, and urban heat generation (George et al., 2007; Akbari et al., 2008). $\mathrm{CO}_{2}$ domes (Rice \& Bostrom, 2011) envelop cities and trap and elevate key climate change drivers such as ozone. Further, urban soils experience increased effective 
precipitation due to watering and runoff (Gill et al., 2007). In cities, natural vegetation patterns are disturbed by the presence of invasive and exotic species, fragmentation and changes in vegetation density (Hall et al., 2002; Lorenz \& Lal, 2009; Ren et al., 2011). Thus, urbanization may, in some ways, act as a space-for-time substitution for the effects of changes in local temperature, precipitation, atmospheric $\mathrm{CO}_{2}$, available nitrogen, and the type and density of resident vegetation that are expected to accompany climate change (Carreiro \& Tripler, 2005; George et al., 2007; Grimm et al., 2008). Insights into future trends in soil organic matter dynamics might therefore be provided by knowledge of the trends of soil organic matter accumulation and dynamics in urban ecosystems.

Compared to natural systems, however, there are relatively few studies of soil organic matter dynamics in urban soils. Consideration of the effects of increased $\mathrm{CO}_{2}$ and elevated temperature on net primary productivity and soil respiration in non-urban systems might lead to speculation that soil organic matter in cities would be low. Nitrogen in cities, though, is also increased, via fertilization, precipitation and dry deposition, which implies that net primary productivity, and rhizodeposition might contribute more carbon substrates, especially where water stress is less of an issue, due to watering by residents. In the few studies that exist, urban areas show considerable variation in the quantity of soil organic matter in resident soils. Both increases and decreases in soil organic matter have been observed following urbanization. For example, Pouyat et al. (2009) suggest that soils in urban ecosystems may store as much as twice the amount of carbon as soils from natural systems due to the effects of management. They propose that anthropogenic drivers of soil organic matter accumulation replace natural ones (Pouyat et al., 2009). In contrast, Jo et al. (2002) found that urban green 
spaces in Chucheon, Korea retain less soil carbon than natural ones and PavaoZuckerman and Coleman (2005) found decreased soil organic matter in urban areas compared to rural ones in Asheville, NC. In some cities, increases in soil organic matter depend on anthropogenic effects, such as time since disturbance. In 2006, Golubiewski found that urban soils equilibrate to greater carbon pools than non-urban native or agricultural land as soon as 25 years after development, suggesting that the factors influencing soil organic matter accumulation may be highly dynamic. The wide variety of patterns of soil organic matter accumulation observed in urban systems suggests that processes controlling soil organic matter accumulation are diverse, and the mechanisms contributing to these differential responses have yet to be fully elucidated. The contrasting results of these studies underscore the need to understand how the mechanisms of soil organic matter accumulation in cities differ from the mechanisms contributing to soil organic matter accumulation in non-urban native soils, if at all. It seems likely that mechanistically divergent processes might explain the variability observed in previous studies, but a mechanistic understanding of the factors influencing soil organic matter accumulation in urban ecosystems is lacking.

The aim of this thesis is to examine the factors influencing soil organic matter dynamics in an urban ecosystem. Using Portland, Oregon as a model system, I used an exhaustive stratified sampling methodology to quantify the effects of soil, vegetation and urban variables on soil organic matter. Further, through direct comparison between soil organic matter stocks in soils of Portland, Oregon and other locales throughout the Pacific Northwest I provide a first indication of the consequences of urbanization for soil organic matter accumulation in soils of this region. Finally, I extend the work presented 
here by examining the differences in soil organic matter accumulation between urban centers and non-urban areas in temperate, desert and tundra biomes throughout the globe with the goal of understanding how biome-specific effects may explain patterns of soil organic matter accumulation in urban ecosystems.

In this thesis, I address three specific hypotheses. First, I investigate the influence of urbanization on soil organic matter accumulation in the Pacific Northwest. As urban landscapes are likely to have lower (or similar) input to soil organic matter pools, greater average soil temperatures and lower seasonal water availability, I predict that soils within Portland will have lower soil organic matter compared to regional, non-urban soils.

Second, I investigate which variables are most important for predicting soil organic matter content of soils Portland's urban ecosystem. Biotic factors such as vegetation type and microbial biomass are thought to strongly influence soil organic matter accumulation in non-urban environments. However, I hypothesize that urban factors such as impervious surface and building footprint area may better predict soil organic matter accumulation in Portland soils, as urbanization disrupts natural soil organic matter accumulation processes like incorporation of detritus and leaf litter.

Finally, I investigate how urban heterogeneity and development history infuence soil organic matter accumulation in Portland by examining patterns of soil organic matter accumulation in four of Portland's neighborhood-scale EcoDistricts. The results presented in this thesis specifically address the three following hypotheses:

1. Soil organic matter accumulates less in Portland than in non-urban ecosystems of the Pacific Northwest. 
2. The pattern of soil organic matter accumulation in Portland soils is primarily influenced by urban metrics such as impervious surface coverage per plot and total building footprint.

3. Soil organic matter accumulation in Portland soils is not influenced by spatial factors such as longitude and latitude or distance from city center. 


\section{Methods}

Portland, Oregon $\left(45^{\circ} 31^{\prime} 12^{\prime \prime} \mathrm{N}, 122^{\circ} 40^{\prime} 55^{\prime \prime} \mathrm{W}\right)$ straddles the Willamette River just south of the Columbia River. It was incorporated in 1851, but settled 200 years previously by Upper Chinook Indians (Marschner, 2008). As of the 2010 census, Portland has a population of 583,776 persons and spatial extent of $133.4 \mathrm{mi}^{2}$, equivalent to $4,375.3$ persons $/ \mathrm{mi}^{2}$ (Portland State University Population Research Center, 2011). In the Pacific Northwest, Seattle, Washington and Vancouver, British Columbia, Canada are more populous than Portland, Oregon (Statistics Canada, 2007; Census Bureau, 2010).

Coarse-loamy and sandy soils with basalt and andesite fragments typify the Multnomah Series, found in Portland. Cation exchange capacity to clay ratio is greater than 0.6 with few anions adhered to clays. The mean annual soil temperature is 8 to $15^{\circ} \mathrm{C}$ (National Cooperative Soil Survey, 2001); mean annual precipitation is 36.03 inches (National Oceanic \& Atmospheric Administration, 2011). The soils are generally moist and well drained with slow runoff and moderate permeability, but are dry up to a depth of 12 inches during the summer season. Soils display minimal horizon formation. Depth of solum, texture shift and bedrock are 20-30 inches, 24-40 inches and more than five feet, respectively (National Cooperative Soil Survey, 2001). Acer, Quercus, Populus, Fraxinus, Salix, Malus, Corylus, Pseudotsuga, Thuja, Symphoricarpos and Rosa are the dominant native genera (National Cooperative Soil Survey, 2001; United States Department of Agriculture, 1983).

All data pertains to plots within four neighborhoods in the city of Portland, Oregon. The neighborhoods, Downtown, Lloyd District, Gateway and Lents, are part of 
a larger project called the EcoDistrict Program that the City of Portland is beginning to develop. The neighborhoods have been surveyed for socioeconomic, transportation and demographic information that is beyond the scope of my research.

\section{Site Selection}

I used a Geographic Information System (GIS) (Shandas, 2008) and a 2007 highresolution digital orthophoto supplied by Portland-METRO to quantify and characterize Portland's vegetation. FRAGSTATS (McGarigal \& Cushman, 2002) and a fishnet grid were applied to the vegetation data using ArcGIS 9.3 to quantify relative percent canopy vs. non-canopy at $25 \mathrm{~m} \mathrm{x} 25 \mathrm{~m}$ resolution. In total, $31225 \mathrm{~m}$ x $25 \mathrm{~m}$ plots were identified within the Portland EcoDistrict boundaries that had a 1:1 ratio of canopy to non-canopy vegetation; 57 in Downtown, 72 in Lloyd District, 75 in Gateway and 108 in Lents. All 312 field plots were then physically scouted and deemed inaccessible (fenced and private property), private (unfenced private property) or accessible (public property). Following inspection for accessibility, 154 accessible sites (55\%) were chosen for sampling (Figure 1): 93\% of Downtown's potential plots, 55\% of Lloyd District's potential plots, $28 \%$ of Gateway's potential plots and $53 \%$ of Lents's potential plots. The latitude and longitude of each site (Appendix B) were recorded using a Trimble Juno SB portable GPS unit with TerraSync software and corrected using GPS Pathfinder Office. In total 48 plots were sampled within downtown, 34 plots were sampled within Lloyd District, 53 in Lents and 19 in Gateway. 


\section{Soil Sampling}

From 26 August through 4 December 2010, I collected and composited three soil cores per plot within an approximately $180 \mathrm{~cm}^{2}$ area using a commercially available 12 " x 1" steel soil corer (Cole-parmer, model R-99025-30). Location of soil samples within each plot was chosen randomly. Slope topography was controlled by sampling only level ground $\left(0-15^{\circ}\right)$. In the field, soil cores were removed from the bore of the coring device using a metal scoopula and composited soil samples were placed in plastic bags and kept on ice, in an ice chest, until they could be refrigerated at $4^{\circ} \mathrm{C}$ at Portland State University. Sampling depth was calculated by averaging the depth of each of the three cores taken per sample. At time of sampling, the soil temperature was measured at sampling depth using a handheld thermocouple with soil probe attachment (Cole-parmer Digi-Sense Thermometer Model 91100-20).

\section{Vegetation Sampling}

Within each plot, all stems within $20 \mathrm{~m}$ of the soil coring locations were exhaustively surveyed. Genus of each perennial plant (trees and shrubs) was noted; where unknown stems were found, pictures and samples were taken for later identification. For all trees, diameter at breast height (DBH) was recorded using an 800 mm DBH Caliper with Gator Eyes (Haglof Mantax); trees larger than $80 \mathrm{~cm}$ in diameter were measured using DBH tape. Canopy area of shrubs was measured with field tape. Distance and bearing to each stem from the soil sampling locations were recorded using a 
laser rangefinder device (Atlanta Advantage RO Laser Rangefinder). Ground cover at the sampling sites, though a possible contributing variable (Qian et al., 2010), was not recorded because ground cover removal and replacement at sampling sites was frequently observed. From these samples, 16 vegetation metrics were analyzed: fine root biomass, stems/ha per plot, trees/ha per plot, shrubs/ha per plot, evergreens/ha per plot, deciduous stems/ha per plot, conifers/ha per plot, dominant functional group per plot, DBH per stem, average DBH per plot, total basal area per plot, most abundant genus per plot, most abundant family per plot, genus with the most basal area per plot, importance values per plot and Shannon Diversity Index per plot.

\section{Laboratory Analyses}

In total, 10 soil metrics were determined: soil organic matter, soil organic carbon, total carbon, total nitrogen, $\mathrm{C}: \mathrm{N}$ ratio, soil temperature, bulk density, soil texture, clay content and soil moisture. Soil texture was determined by hand texturing and categorized into one of eleven textural classes (Brady \& Weil, 2008). To determine bulk density, a $64 \mathrm{~cm}^{3}$ (the volume of a 2" depth x 2" diameter brass ring) of soil from each sampling location was dried in tin envelopes at $105^{\circ} \mathrm{C}$ for 48 hours and subsequently weighed. Any rocks or gravel in the sample were removed and weighed; their volume was measured by water displacement. The mass and volume of the rocks was subtracted from the soil dry weight and soil volume, respectively. To determine root biomass, three $10 \mathrm{~g}$ (field moist) subsamples of the composited soil were randomly chosen and all visible root tissue was manually harvested and weighed fresh. The remaining soil of each 
commingled sample was sieved with $2 \mathrm{~mm}$ mesh (Brass Cole-parmer USA Standard Test Sieve ASTM E-11 Specification). $15 \mathrm{~g}$ subsamples of field-moist soil were weighed and then subsequently dried at $105^{\circ} \mathrm{C}$ for 48 hours to determine soil water content by mass difference. Dry samples were stored in desiccators with Drierite.

Microbial biomass of the residual soil from the three rootless samples was determined by chloroform fumigation and microbial biomass carbon extraction. The replicates were placed in a vacuum desiccator with $25 \mathrm{~mL}$ ethanol-free chloroform, which was boiled three times for two minutes each by drawing a vacuum. The desiccator was vented between each vacuum application. The final vacuum was maintained and the desiccator was covered with two black, plastic bags for five days. Following fumigation, the soil samples were transferred to $125 \mathrm{~mL}$ flasks and $50 \mathrm{~mL} 0.5 \mathrm{M} \mathrm{K}_{2} \mathrm{SO}_{4}$ was added. The soil slurry was shaken for one hour and then filtered using a 20-25 $\mu \mathrm{m}$ filter (Whatman Grade 4). Samples were stored at $-20^{\circ} \mathrm{C}$ until they were analyzed for nonpurgeable organic carbon using a Shimadzu TOC-V CSH total organic carbon analyzer. TOC Control V software was used to program the total organic carbon analyzer. Standard total carbon and inorganic solutions (1000 ppm C each) were prepared using potassium hydrogen phthalate and a mixture of sodium hydrogen carbonate and sodium carbonate, respectively (Shimadzu Corporation, 2001). Standard curves were constructed by measuring peak areas under diluted standard solutions $(10,25,50,100,150,200,250$, 300, 400 and $500 \mathrm{ppm} \mathrm{C}$ ) and nanopure water (0 ppm C) and finding the best linear relationship. Microbial biomass was calculated by dividing the chloroform labile C (NPOC) by 0.45 (Beck et al., 1997). 
Soil organic matter of composited samples was measured by loss-on-ignition using modifications to Smith (2003). $10 \mathrm{~g}$ sieved, dried soil was heated to $550^{\circ} \mathrm{C}$ for three hours in a muffle furnace in ceramic crucibles. A temperature controller (Watlow) was used to heat the dry samples to $550{ }^{\circ} \mathrm{C}$, keep the temperature stable for three hours and then cool the ignited samples to $105^{\circ} \mathrm{C}$ until they were placed in desiccators with Drierite, where they were cooled to room temperature before being weighed. Soil organic carbon is calculated as 50\% of soil organic matter (Brady \& Weil, 2008; Pribyl, 2010) for use in comparison to studies that do not report loss-on-ignition data.

Consideration of the ongoing disagreement regarding the correct conversion factor from soil organic matter to soil organic carbon, especially arguments discussed by Pribyl (2010) regarding empirical evidence that the traditional 58\% conversion factor is incorrect, compelled me to use the $50 \%$ conversion factor.

Total carbon and total nitrogen were measured by elemental analysis on a Flash EA 1112 elemental analyzer using standard operating procedures for NC-Soils (Thermo Scientific, 2005). Eager Xperience software (Part No. 317110 55, Revision B, September 2009) was used to program the elemental analyzer. Samples were stored in desiccators with Drierite until they were analyzed for total carbon and total nitrogen. Samples were homogenized using a mortar and pestle in preparation for analysis. Elemental tin crucibles were used to contain the samples to be analyzed. Aspartic acid and Reference Standard Soil (Thermo Scientific Soil Reference Material Part No. 338 400 26) were used to calibrate the analyzer before each use; Eager Xperience software (Thermo Scientific, 2009) generated curves automatically. 


\section{Quantification of Urban Metrics}

Latitude and longitude of each plot were added as a layer in a GIS using ArcGIS 10. The November 2010 Regional Land Information System (RLIS) tax lot shape file was added to the GIS, which provided total value (real market value of land and buildings), square footage of buildings, years since development and footprint (in acres)

of buildings; the information was originally supplied by the Metro Data Resource Center. Impervious surface data was obtained from the National Land Cover Database as a total impervious area shape file, also added to the GIS. A $20 \mathrm{~m}$ buffer surrounding the latitude and longitude coordinates was used to constrain the above urban variables. Distance to urban center was calculated using Pioneer Courthouse Square as the urban center in Portland. Maps supplied by the City of Portland (City of Portland, 2010, 2011) were used to assign years since annexation and zoning code for each plot. EcoDistrict, years since annexation, zoning code, distance to urban center, impervious surface coverage per plot, total value of buildings within $20 \mathrm{~m}$ of sampling site, total square footage of buildings within $20 \mathrm{~m}$ of sampling site, average years since development of buildings within $20 \mathrm{~m}$ of sampling site and total footprint of buildings within $20 \mathrm{~m}$ of sampling site are the nine urban variables collected for analysis.

\section{Statistical Analyses}

ArcGIS 10 was used to generate spatial urban data specific to each plot. FRAGSTATS was used to calculate landscape metrics for each plot. R statistical 
software version 2.13.0 (R Development Core Team, 2011) was used to perform all additional statistical analyses. Analyses of Variance (ANOVA), with all categorical variables used as factors for soil organic matter, were performed. Where appropriate, log transformation was employed to normalize distributions of independent variables before ANOVA were conducted. Principal Components Analysis (PCA) was performed on the urban variables to determine their suitability as a set of regressors along which non-urban variables might change. To examine the spatial heterogeneity of soil organic matter in Portland, multiple regression analyses and ANOVA were conducted for each EcoDistrict. To determine which factors influence soil organic matter accumulation in Portland, I performed multiple regression analysis of soil, vegetation and urban factors against soil organic matter using an all-possible regressions procedure (Kleinbaum et al., 1998; Lumley, 2009). This allowed me to test whether the same variables that influence soil organic matter accumulation in Pacific Northwest forest soils are also influential in Portland, or, alternatively, that urban variables govern soil organic matter accumulation in an urban area. Mallow's $\mathrm{C}_{\mathrm{p}}$ was used to determine the best sub-models and an overall model. Thirty-two quantitative independent variables were tested for their ability to accurately predict soil organic matter by assigning the independent variables to one of three sub-models.

The ability of the traditional soil-forming paradigm to predict soil organic matter was tested using the factor-based sub-models. The factor-based sub-models were generated by grouping the quantitative independent variables by soil forming factor. The biology sub-model includes total nitrogen, microbial biomass, fine root biomass, stems/ha, trees/ha, shrubs/ha, evergreens/ha, deciduous stems/ha, conifers/ha, average 
DBH, total basal area and Shannon Diversity Index. The texture sub-model includes bulk density and clay content. The climate sub-model includes day of year, soil temperature and water content. The time sub-model includes years since annexation and years since development.

Additionally, the Pacific Northwest-based sub-model tests the variables that are crucial for the accumulation of soil organic matter in Pacific Northwest forest studies. Specific variables found to be significant predictors of soil organic matter in Pacific Northwest forest soil studies were tested singly. The correlation between soil organic matter and average $\mathrm{DBH}$, stem density, microbial biomass, total nitrogen, soil moisture, clay content and years since development was initially examined using Pearson's correlation coefficient and then variables significantly correlated to soil organic matter (total nitrogen, microbial biomass and water content) were combined to create the Pacific Northwest-based sub-model.

Finally, an urban-based sub-model was constructed using urban variables, which I hypothesize strongly influence soil organic matter in Portland. The urban-based submodel tests the urban variables' ability to predict soil organic matter. The urban-based sub-model comprises distance to urban center, impervious surface coverage, total value, building square footage and building footprint.

To develop the overall model, significant variables $(\alpha=.05)$ from all sub-models were combined, including total nitrogen, microbial biomass, bulk density, soil temperature, water content and years since development. After regression analysis was performed, variables that failed to significantly contribute to model performance were eliminated. The abilities of each sub-model and the overall model to predict soil organic 
matter were compared using residual sums of squares generated by ANOVA. The overall model predicts soil organic matter using microbial biomass, bulk density and total nitrogen as independent variables.

\section{Comparative Analyses}

Seven previously published Pacific Northwest studies (Klopatek, 2002; Homann et al., 2004; Sun et al., 2004; Homann et al., 2007; Chaer et al., 2009; Griffiths et al., 2009; Kluber et al., 2010) that contain soil organic carbon data were used to compare urban to undisturbed soils. Where necessary, reported bulk density was used to convert between $\mathrm{Mg} / \mathrm{ha}$ and $\mathrm{g} / \mathrm{kg}$. Only data from samples taken from the A horizon or superficial $30 \mathrm{~cm}$ were used. 


\section{Results}

Over 300 potential research plots were identified from our analysis of the digital orthophotograph and 154 plots were ultimately found suitable for inclusion in this study: 48 in Downtown, 34 in Lloyd District, 53 in Lents and 19 in Gateway. The uneven distribution of plots among EcoDistricts results from differences in the number of potential plots and differences in accessibility. Results of analyses associated with each EcoDistrict are possibly unreliable due to insufficient sampling size, but results associated with all $15425 \mathrm{~m} \times 25 \mathrm{~m}$ research plots are robust.

\section{Vegetation Analyses}

Although the 154 plots were chosen because they displayed the 1:1 ratio of high structure to low structure vegetation (as inferred from analysis of the high-resolution digital orthophotograph), field-surveys revealed that there were significant differences in above-ground vegetation structure among the four EcoDistricts (Tables 1-4). Lloyd District has significantly fewer stems (512.703/ha) than the other EcoDistricts (average $\approx$ 986.709/ha) (Figure 1). Downtown has the greatest basal area $\left(1.867 \mathrm{~m}^{2}\right)$, Lents and Lloyd significantly less (average $\approx 0.807 \mathrm{~m}^{2}$ ) and Gateway is indistinguishable from the two extremes (Figure 1). Average DBH did not vary among EcoDistricts.

Plant functional type differed between EcoDistricts to some extent as well. Lents has significantly more trees $(423.6075 /$ ha) than Downtown and Lloyd District (average $\approx$ 253.387/ha), and Gateway is indistinguishable from either of these two groups (Figure 1). 
Gateway has the most shrubs (813.021/ha), followed by Lents (490.423/ha); Downtown and Lloyd District have fewer shrubs and are indistinguishable (average $\approx 257.189 / \mathrm{ha}$ ) (Figure 1). Gateway has the most evergreens $(829.411 / \mathrm{ha})$, Lents is indistinguishable from both Gateway and Downtown, which has an intermediate number of evergreen stems (284.531/ha), and Lloyd District has the fewest evergreens (235.756/ha) (Figure). Conifer density in Gateway and Lents are indistinguishable and is the highest (average $\approx$ 197.385/ha); Downtown and Lloyd, also indistinguishable, contain fewer conifers (average $\approx 26.570 /$ ha) (Figure 1). Downtown, the dominant functional group is deciduous trees; Lloyd District's and Gateway's dominant functional group is evergreens; the dominant functional group in Lents is shrubs. There were no significant differences between deciduous stems/ha among the EcoDistricts.

Similar to results for plant functional type, there are significant differences in the diversity of plant genera observed in each EcoDistrict. Lents (98 genera) has a significantly higher Shannon Diversity Index (1.726), followed by Gateway $(1.389,48$ genera); Downtown (77 genera) and Lloyd District (56 genera) are indistinguishable (average $\approx 1.010$ ) (Figure 1). Additionally, in Gateway, the genus with the highest importance value and the genus with the most basal area distinguished plots in terms of soil organic matter content. Finally, Analysis of Similarity (ANOSIM) shows that genus composition differs between Lents and Lloyd District and Lents and Downtown (Figure 2). Downtown and in Lloyd District, the most abundant genus is Acer and the most abundant family is Sapindaceae. In Gateway, the most abundant genus is Pseudotsuga and the most abundant family is Cupressaceae. In Lents, the most abundant genus is 
Rosa and the most abundant family is Rosaceae. In all EcoDistricts, the genus with the most basal area and with the greatest importance value is Acer.

When results from all plots are considered I found that the average stem density is 882 stems $/$ ha (2,907 total stems). Tree diameter averages $28.8 \mathrm{~cm}$ and mean basal area averages $48.76 \mathrm{~m}^{2} / \mathrm{ha}$. There are a wide variety of genera of trees and shrubs in the 154 research plots (Appendix A). Evergreen stems and shrubs (deciduous and evergreen), which compose $46.7 \%$ and $46 \%$ of all stems, respectively, dominate vegetation throughout Portland. Specific functional types average: 412 evergreens/ha, 406 shrubs/ha, 328 trees/ha 278 deciduous stems/ha and 106 conifers/ha. The most abundant genus of plant in Portland is Acer, which includes only trees, and the most abundant family is Rosaceae, which includes trees and shrubs. Acer is the genus with the most basal area/ha and the highest importance value throughout the city. Portland's Shannon Diversity Index value is 1.303 (Table 5), comprising 162 genera.

\section{Soil Analyses}

Field-surveys revealed that there were some significant differences in soil properties among the four EcoDistricts. Lents and Lloyd District have greater total nitrogen (average $\approx 3.216 \mathrm{~g} / \mathrm{kg}$ ) than Downtown $(2.039 \mathrm{~g} / \mathrm{kg}$ ), and Gateway is indistinguishable from either group (Figure 3). Downtown and Lloyd have a larger C:N Ratio (average $\approx 18.789$ ) than Lents (14.674), and Gateway, again, is indistinguishable from either group (Figure 3). Total carbon (47.872 g/kg), fine root biomass $(25.866 \mathrm{~g} / \mathrm{kg})$, 
microbial biomass $(74.66 \mu \mathrm{g} / \mathrm{g})$ and soil organic matter $(107.25 \mathrm{~g} / \mathrm{kg})$ did not significantly vary among EcoDistricts (Tables 6-9).

There are significant differences in soil physical properties observed in each EcoDistrict. Lloyd District has a significantly lower bulk density $\left(0.551 \mathrm{~g} / \mathrm{cm}^{3}\right)$, than the other EcoDistricts, which are indistinguishable (average $\approx 0.752 \mathrm{~g} / \mathrm{cm}^{3}$ ) (Figure 3). Soils in Gateway and Lents are the most clayey (average $\approx 37.986 \%$ ) and Downtown and Lloyd District are significantly less clayey (average $\approx 23.390 \%$ ) (Figure 3). Soil Texture in Downtown and Lloyd District is coarse loamy sand; soil texture in Gateway is fine clay; soil texture in Lents is fine silty clay.

When considered across all four EcoDistricts, soil organic matter makes up approximately $10.74 \%$ of the A horizon in Portland (Figures 5 and 6). Total carbon concentration averages $47.782 \mathrm{~g} \mathrm{C} / \mathrm{kg}$ soil and total nitrogen concentration averages $2.872 \mathrm{~g} \mathrm{~N} / \mathrm{kg}$ soil; $\mathrm{C}: \mathrm{N}$ ratio is 17.096 . Mean microbial biomass carbon was found to be $74.659 \mu \mathrm{g} \mathrm{MBC/g}$ soil. Mean fine root biomass was found to be $25.866 \mathrm{mg}$ fresh weight/g soil. The predominant soil texture is coarse loamy sand; mean clay content is $30 \%$. Bulk density averages $0.71 \mathrm{~g} / \mathrm{cm}^{3}$.

\section{Analysis of Urban Metrics}

Some urban variables differ between EcoDistricts (Tables 11-14). Downtown was annexed first (123.958 years ago), followed by Lloyd District (101.177 years ago), then Lents (61.698 years ago) and finally Gateway (23.158 years ago) (Figure 7). Downtown is also closest to the urban center $(.899 \mathrm{~km})$, followed by Lloyd District 
$(2.041 \mathrm{~km})$, then Gateway $(9.396 \mathrm{~km})$ and finally Lents $(10.025 \mathrm{~km})($ Figure 7$)$.

Downtown and Lloyd District have the most impervious surface (average $\approx 72.71 \%$ ), Gateway has an intermediate amount (60.76\%) and Lents (51.10\%) has the least (Figure 7). Downtown and Lloyd District have the most average building square footage $(72,465$ $\left.\mathrm{ft}^{2}\right)$, Lents the least $\left(4,219 \mathrm{ft}^{2}\right)$, and Gateway is indistinguishable from either groups (Figure 7). The most prevalent zoning code in Downtown and Lloyd District is central commercial; Gateway is mostly zoned central commercial and institutional residential; and Lents's most prevalent zoning code is open space. Average years since development does not differ among EcoDistricts.

Across Portland, time since annexation at the sampling plots averages 85 years, and time since development averages 31 years. Zoning classification is primarily central commercial. The mean footprint of tax lots within a $20 \mathrm{~m}$ radius of each sampling location is 2.546 acres. The average square footage of the buildings within $20 \mathrm{~m}$ of sampling locations is $47,481 \mathrm{ft}^{2}$ and the mean value of the land and buildings combined is approximately $\$ 9$ million. Impervious surface in a radius of $20 \mathrm{~m}$ surrounding each sample averages $63.8 \%$ (Table 15).

Principal component analysis of the urban variables revealed that the urban characteristics are heavily loaded onto individual components. Principal components analysis was performed on the urban variables to determine the suitability of the variables as a set of regressors against the soil and vegetation data. However, I found that all of the variation in the urban variable set loaded onto one principal component and each urban variable loaded separately onto its own independent axis (Table 16). 


\section{Correlates to Soil Organic Matter Content in Portland Soils}

Soil organic matter among Downtown plots can be estimated by measuring only two soil characteristics: total carbon and total nitrogen (Eq 1, Table 17). To estimate soil organic matter among Lloyd District plots, however, soil attributes (total carbon, total nitrogen, soil temperature, bulk density and soil moisture), vegetation structure (Shannon Diversity Index) and urban variables (impervious surface coverage and total value of adjacent tax lots) must be measured (Eq 2, Table 18). Soil organic matter among Gateway plots can be estimated by measuring total carbon, total nitrogen and the number of conifers per hectare (Eq 3, Table 19). Soil organic matter in Lents can be estimated by measuring total carbon, total nitrogen and the number of trees per hectare (Eq 4, Table 20).

Eq 1. $\mathrm{SOM}_{\text {Downtown }}=-234.58 \times \log ($ Total Carbon $)+516.73 \times \log ($ Total Nitrogen $)+98.07 \times \operatorname{sqrt}(\mathrm{C}: \mathrm{N}$ Ratio $)+-63.36$

Eq 2. $\quad \mathrm{SOM}_{\text {Lloyd }}=-617.27 \times \log ($ Total Carbon $)+928.34 \times \log ($ Total Nitrogen $)$ $+314.00 \times \operatorname{sqrt}(\mathrm{C}: \mathrm{N}$ Ratio $)+-36.80 \times($ Shannon Diversity Index $)+-1.72$ $\times($ Impervious Surface $)+4.37 \times \log ($ Total Value $)+-2312.45 \times \log ($ Day of Year $)+-8.93 \times($ Temperature $)+-98.93 \times($ Bulk Density $)+3.50 \times$ $($ Soil Moisture $)+13400.86$ 
Eq 3. $\mathrm{SOM}_{\text {Gateway }}=117.97 \times \operatorname{sqrt}(\mathrm{C}: \mathrm{N}$ Ratio $)+0.98 \times \operatorname{sqrt}($ Conifers $/$ ha $)+$ $-384.27$

Eq 4. $\quad \mathrm{SOM}_{\mathrm{Lents}}=88.98 \times \log ($ Total Nitrogen $)+35.61 \times \operatorname{sqrt}(\mathrm{C}: \mathrm{N}$ Ratio $)+-0.21$ $\times \operatorname{sqrt}($ Trees/ha) +-154.95

With the exception of fine root biomass, all vegetation variables were uncorrelated with soil organic matter when considering Portland as a whole. Significant differences in soil organic matter do not exist among genera, among dominant functional types at each site or among sites where different genera had dominant importance values. Significant differences in soil organic matter do not exist between textural classes. None of the urban characteristics that I measured were correlated with soil organic matter. Significant differences in soil organic matter do not exist between different zoning designations.

Fine root biomass, total carbon, total nitrogen, water content, bulk density and microbial biomass correlate strongly with soil organic matter. Of these factors, total nitrogen, microbial biomass and bulk density are significant predictors of soil organic matter in Portland according to the overall regression model (Equation 5, Table 21, Figure 8).

Eq 5. Soil Organic Matter $=66.01 \times \log ($ Total Nitrogen $)+24.44 \times$ $\log ($ Microbial Biomass $)+-118.41 \times($ Bulk Density $)$ 
Factor-based, Pacific Northwest-based and urban-based sub-models yield congruent results. The same variables remain significant or insignificant no matter which specific sub-model they are a part of. Many variables have no predictive power: years since annexation, years since development, distance to urban center, footprint of adjacent tax lots, zoning designation, shrubs/ha, evergreens/ha, deciduous stems/ha, average DBH, total $\mathrm{DBH}$, stems/hectare, total basal area, fine root biomass, soil texture, clay content and sampling depth were neither significant in any EcoDistrict nor in Portland as a whole.

Comparison of soil organic matter in Portland and the Pacific Northwest

Figure nine compares seven Pacific Northwest studies (Table 22) of undisturbed forest soil to the data I collected in Portland. Soil organic carbon (soil organic matter $\times$ 0.50) was used for the comparison because many studies do not report soil organic matter. The two samples are statistically indistinguishable, though there is greater variety in the Pacific Northwest data set. 


\section{Discussion}

The aim of this study was to examine the factors influencing soil organic matter storage in an urban ecosystem by quantifying how biotic and urban variables influence soil organic matter dynamics in Portland, Oregon. As soil organic matter is a critical component of the global carbon cycle, understanding the factors influencing soil organic matter dynamics is fundamental to our abilities to predict how components of global change, including urbanization, might influence the carbon storage potential of soils. Previous studies have primarily focused on the roles of biology (Klopatek, 2002; Sun et al., 2004; Adams et al., 2005; Rezácová et al., 2006; Chaer et al., 2009; Eskelinen et al., 2009, 2009; Kluber et al., 2010; Waldrop et al., 2010; Blagodatskaya et al., 2011; Crow et al., 2009b; Johnson et al., 2009), parent material (Adams et al., 2005; Homann et al., 2007; von et al., 2008; Johnson et al., 2009; Kong et al., 2009), climate (Homann et al., 2004; Sun et al., 2004; Raich et al., 2006; Homann et al., 2007; Griffiths et al., 2009) and time (Sun et al., 2004) in influencing soil organic matter dynamics. Research conducted in Pacific Northwest forests indicates that several soil-forming factors contribute to soil organic matter accumulation.

Biology has been found to be a significant contributor to soil organic matter in Pacific Northwest forest soils. Sun et al. (2004) found that soil carbon accumulated as a function of increased primary productivity, as measured by tree and shrub dimensions and biomass calculations. In his 2002 study, Klopatek (2002) attributed greater soil carbon to increased detrital pool input from coarse woody debris. Chaer et al. (2009) found that soil organic carbon is strongly correlated with microbial biomass and 
phosphatase activity due to the greater nutritional value of soil organic matter-rich soil. Nitrogen concentration has been seen to variably affect soil organic matter. Klopatek (2002) found that nitrogen fertilization reduced soil respiration and decomposition; Homann et al. (2001) found that nitrogen fertilization decreased soil respiration, cellulase activity and possibly contributed to the formation of recalcitrant organic matter, although no effect on soil organic carbon pools was found; and Adams (2005) found that soil carbon significantly increased with nitrogen fertilization. Significant increases in soil organic matter have been attributed to increased precipitation in studies conducted by Sun et al. (2004), Homann et al. (2004, 2007) and Griffiths et al. (2009). In a regional study, Homann et al. (2007) found no response in soil carbon to increasing temperature. They attribute this to greater detrital input, affected by mixing by soil fauna, which balances the enhanced decomposition of higher temperature soils. Texture was found to be a significant factor in some Pacific Northwest studies as well: Homann et al.'s 2007 study found that clay content and soil organic matter were directly related. Finally, time has proven a significant variable in Pacific Northwest soil organic matter research. Sun et al. (2004) discovered that forest stands less than 50 years old suffered from soil organic carbon loss, but after that amount of time, soil organic carbon accumulates until forest stand age reaches approximately $150-200$ years, at which time it plateaus.

In Pacific Northwest soils, then, it seems that greater above-ground biomass leads to greater detrital input and both increase soil organic matter. Wetter soils limit decomposition and retain soil organic matter. Greater soil nitrogen contributes to above ground biomass and possibly limits decomposition of existing soil organic matter. A soil organic matter steady state seems to be reached at about $150-200$ years. 
Surprisingly, most traditional soil forming factors do not correlate to or predict soil organic matter content in Portland. Exhaustive sampling of 154 discrete research plots in Portland indicates that soil organic matter is primarily predicted by microbial biomass, nitrogen and bulk density. After modeling each factor separately, combining significant variables into one model and eliminating insignificant variables, the overall predictive soil organic matter model includes only microbial biomass, total nitrogen and bulk density. The accumulation of soil organic matter in Portland likely depends on above ground biomass, dominant vegetation genera, rhizodeposition, effective precipitation and clay content in addition to nitrogen content, microbial biomass and bulk density, as is the case for Pacific Northwest forest soils, but the effects of those variables appear to have been masked by urbanization.

Numerous previous studies have suggested that vegetation plays a key role in modulating soil organic matter content. For example, in their meta-analysis, Cebrian and Duarte (1995) found a strong linear correlation between carbon entering the detrital pool and primary productivity. The importance of plant community composition has also been documented. Eskelinen et al. (2009) found that the proportion of forbs to woody shrubs alters the quality of soil organic matter, specifically the proportions of soluble $\mathrm{N}$, phenolics and the $\mathrm{C}: \mathrm{N}$ ratio. Further, this difference in vegetation is associated with fungi-dominated (shrubs) or bacteria-dominated (forbs) microbial communities (Eskelinen et al., 2009). Similarly, Johnson et al. (2009) found that mixed forest stands correspond with greater soil organic matter than homogenous stands (Johnson et al., 2009). The mechanism by which species richness leads to increased soil organic matter 
may be two-fold: decreased soil carbon losses and stimulation of deposition (Steinbeiss et al., 2008).

Tsuga, Pseudotsuga and Abies dominate Pacific Northwest forests (Schoonmaker \& McKee, 1988). Belowground ectomycorrhizal mats are extensive in such forests (Griffiths et al., 1996), where net primary productivity (Homann et al., 2007) and the amount of coarse woody debris found on the forest floors influence soil organic matter stocks. Portland has shifted to a deciduous dominated vegetation cover. This shift in vegetation does not appear to significantly affect soil organic matter, however, because fine root biomass is the only vegetation variable correlated to soil organic matter; fine root biomass is not correlated to any other vegetation variable (stem density, Shannon diversity index, etc.). This implies that the amount and composition of vegetation in Portland does not directly affect soil organic matter.

In contrast, a recent meta-analysis comprising several studies on decomposition indicates that plant community composition is important in determining the extent to which litter decomposes (Cornwell et al., 2008). Cornwell et al. assert that correctly interpreting the relationship between community composition and litter decomposition rates is crucial for understanding carbon cycling. However, urban ecosystems, where blowers, raking, mowing etc. remove surface litter, defy the traditional paradigm of carbon inputs and decomposition dynamics.

Litter removal experiments reveal that soil organic matter beneath deciduous forests is stabilized by rhizodeposition, whereas needle litter produced in coniferous forests induces a priming effect (Crow et al., 2009b). As the vegetation shift in Portland is from a coniferous dominated vegetation pattern to a deciduous pattern, the rate of 
below-ground input may have increased. Also, rates of decomposition of soil organic matter in Portland may be lower than decomposition rates in Pacific Northwest forests due to the elimination of a needle litter induced priming effect following the shift in tree community composition with urbanization. Conceivably, higher rates of rhizodeposition, coupled with low microbial biomass have acted to recover soil organic matter that was lost with initial disturbance in Portland, but whether rhizodeposition is greater in Portland compared to Pacific Northwest forests can only be speculated. Further, none of the regression models, either specific to an EcoDistrict or for Portland, include fine root biomass, so the direction of the correlation between fine root biomass and soil organic matter remains conjecture. It is reasonable to imagine that greater soil organic matter might support groundcover with more extensive root structure.

Differences in quality of below-ground carbon substrates between Portland and Pacific Northwest soils may also exist. The shift in above-ground vegetation may have altered rhizodeposited carbon sources and the ability of the microbial community to modify root-derived litter. In urban litter-bag experiments, Vauramo and Setälä (2011) found that the nearby plant community did not affect decomposition rates, while litter type did, suggesting that above-ground litter may have more effect than below-ground litter on soil organic matter composition. However, the mycorrhizae beneath conifers confer specific metabolic capabilities to the soil microbial community (Kluber et al., 2010) and their displacement in Portland may have shifted the identity or enzymatic profiles of the soil microbiota, limiting their ability to decompose available substrates.

Some Pacific Northwest studies (Sun et al., 2004; Griffiths et al., 2009) suggest that soil characteristics indirectly affect soil organic matter by influencing microbial 
biomass and decomposition rates. Microbial biomass in Portland is significantly lower than values reported for Pacific Northwest forests (Selmants et al., 2005; Chaer et al., 2009; Kluber et al., 2010), suggesting that soil respiration in Portland may be lower than in Pacific Northwest forests. Considering the reduced microbial biomass, the most probable scenario explaining the lack of difference between Portland and Pacific Northwest soil organic matter is reduced carbon input and accompanying reduced decomposition in Portland compared to Pacific Northwest forests. Alternatively, increased carbon input, via rhizodeposition, and increased decomposition may be occurring. One method to distinguish these two possibilities would be to examine the activity of the microbial community by measuring soil respiration.

Biomass, activity, respiration rate and metabolic quotient of soil microbiota are likely universally important in understanding the timescales of soil organic matter turnover and the mechanisms of its accumulation and degradation. For example, a recent laboratory study found that the magnitude of priming effect depends on the existing microbial biomass (Blagodatskaya et al., 2011). Similarly, the low metabolic quotient and carbon flux of arctic permafrost depend on low microbial biomass rather than soil organic matter recalcitrance (Waldrop et al., 2010). In a laboratory study, Rezacova et al. (2006) tested the response of fulvic and humic acids, which are major constituents of soil organic matter, in incubations with different communities of microfungi. They found that the chemical complexity of soil organic matter decreased in the presence of the basidiomycete Trametes versicolor implicating microbial community composition in regulating soil organic matter (Rezácová et al., 2006). 
Insufficient data limits knowledge of the role of microorganisms in Portland's soils. While microbial biomass is significantly lower in Portland than in Pacific Northwest forest soils, the activity of the microbial biomass, soil enzymatic profile and community composition remain unexplored. Low soil microbial biomass generally indicates low soil organic matter content (Nourbakhsh, 2007; Chaer et al., 2009). Low microbial biomass coupled with ambient soil organic matter implies that soil microbial activity in Portland may be low. Further, a low microbial biomass to soil organic matter ratio signals slow biogeochemical cycling of key plant nutrients (Wang et al., 2011). Additionally, low microbial biomass may mean that Portland's soils are vulnerable to soil priming because relatively small amounts of readily available carbon substrate will trigger the priming effect (Blagodatskaya et al., 2011).

The effect of urbanization on soil microbial biomass has been studied but little. Many of the urban studies that examine soil microbial communities and their functions focus on the effects of urban heavy metal contamination. In Aberdeen city, Scotland, Yang et al. (2006) recently found that the metabolic quotient of soil microbiota is comparable in urban and non-urban areas, but that the rate of carbon substrate utilization is higher and soil organic carbon is lower in cities. They speculate that their results may be explained by heavy metal contamination of urban soils (Yang et al., 2006). Yakovlev et al. (2008) also cite heavy metal contamination as a causative agent of soil organic matter differences between urban and native soils. In Norilsk, Russia, though, soil organic matter increased by approximately $150 \%$ (Yakovlev et al., 2008). Wang et al. (2011) found that microbial biomass and activity were not significantly disturbed by heavy metal contamination. More perplexing than inconsistencies in the effects of 
urbanization on soil microbial biomass and activity is the notion that disturbance not only alters soil biology, but disrupts relationships and correlations among soil properties (Nourbakhsh, 2007).

Urbanization is a significant disturbance event for soils (Lehmann \& Stahr, 2007), physically, chemically and biologically. Urban characteristics, such as time since disturbance (Scharenbroch, 2005; Golubiewski, 2006) and distance to urban center (Sun et al., 2010), have proven significant explanatory variables in other urban soil organic matter studies. In contrast, urban variables have a limited effect on soil organic matter accumulation in Portland. The amount of soil organic matter in Portland is not statistically distinguishable from the amount in Pacific Northwest forest soils, urban variables do not correlate with soil organic matter, nor are they significant regressors of soil organic matter and the urban landscape does not combine to form an ecological gradient, as non-urban ecosystem attributes do. Urbanization of the Pacific Northwest appears not to have directly affected soil organic matter accumulation.

That urban variables are not significant predictors of soil organic matter in Portland is, perhaps, unsurprising, considering that there is no significant difference in soil organic matter between Portland and Pacific Northwest forest soils. If there had been a significantly greater or lesser amount of soil organic matter between the two areas, it would be reasonable to expect to find the urban metric (or combination of metrics) responsible. Possibly, an important urban variable was overlooked. For example, investigation into social aspects of urbanization, such as management or demographics, may have proved fruitful. 
The influence of urbanization on native Pacific Northwest soils may manifest only as an artificial steady state. In Pacific Northwest forests, soil organic matter declines for approximately 50 years after disturbance, implying that soil organic matter in Portland (where the average number of years since development is 50) is decreasing. But, as the pool of soil organic matter in Portland is statistically indistinguishable from that in Pacific Northwest forest soils, the notion that soil organic matter in the Portland area preurbanization was significantly greater than it is now is doubtful. If urban soil organic matter is not decreasing, it must either be at equilibrium or it must be increasing. I suggest that if urban soils were left undisturbed, they would accumulate soil organic matter. But, it seems that urban soils are not be left undisturbed. There is no correlation between years since annexation and years since development; that is, even locations in Portland that have been urban for over a century have been developed (redeveloped) within the last decade. Portland's soils are harassed by frequent disturbance.

In Portland, it seems that nearly all input to the soil organic matter pool must be below-ground via rhizodeposition of deciduous trees. High microbial biomass, high nitrogen and low bulk density predict soil organic matter. Frequent disturbance precludes further buildup of soil organic matter. Three possible mechanisms explain the parity between Pacific Northwest and Portland soils. First, input and loss from Pacific Northwest and Portland soils could be comparable. That is, rhizodeposition from Portland's maples might balance above-ground litter from Pacific Northwest conifer stands and decomposition in Portland's microbial biomass-poor soils might balance wetter Pacific Northwest soils. However, it seems implausible that below-ground input from fewer, smaller trees in Portland is able to match above- and below-ground input 
from more, larger trees in the Pacific Northwest forests. If input to soil organic matter pools in Portland are reduced compared to Pacific Northwest forests, then decomposition of soil organic matter must also be reduced. The fact that Portland receives less precipitation than Pacific Northwest forest soils challenges this hypothesis, but it is supported by the fact that Portland sustains less microbial biomass than Pacific Northwest forest soils (Table 23).

Responses of soil organic matter to urbanization in temperate cities vary widely. Compared with other temperate urban cities, Portland contains more soil organic matter than some cities and less than others (Figure 12). The difference between the amount of soil organic matter in the Pacific Northwest and Portland is intermediate compared to differences in soil organic matter between temperate native non-urban soils and temperate city soils (Figure 13), which range from $-27 \%$ to $157 \%$. My results reinforce traditional concepts of soil organic matter and soil organic matter accumulation in an urban area and support the framework proposed by Pickett and Cadenasso (2009), where the five state factors (parent material, biology, climate, topography and time) (Jenny, 1946) are affected by urbanization as they would be by any other cause of disturbance. Soil organic matter accumulation in cities may not be fundamentally different than soil organic matter accumulation in undisturbed areas. In as much as cities have similar biology, parent material, climate, texture and topography they will have similar soil organic matter values.

Several studies, conducted in a variety of biomes, have reported soil organic matter. Soil organic matter in undisturbed soils appears to be greater in climates with lower temperatures (Figure 11). Far less research has been undertaken to examine the 
factors that influence increases or decreases in soil organic matter with urbanization. Biome-specific processes may underlie the wide variation in soil organic matter observed in urban studies (Figure 12). For example, the heterotrophic respiration of soil organic matter is sensitive to soil temperature in tropical, temperate and boreal biomes but to increasing degrees, respectively (Chen \& Tian, 2005). Further evidence that regional or biome-scale environmental conditions influence the effects of urbanization on soil organic matter may be seen by comparing reported differences in soil organic matter after urbanization in different biomes. After urbanization, soils equilibrate to higher, similar and lower amounts of soil organic matter, and differences between biomes can be discerned. Urban areas in desert biomes have greater soil organic matter than their undisturbed counterparts whereas in temperate biomes, urbanization has mixed effects on soil organic matter (Figure 13). In deserts, constraints to soil organic matter accumulation are likely related to water stress and lack of carbon input, which are alleviated in urban areas due to residential installation of lawns and their concomitant management (Green \& Oleksyszyn, 2002; Jenerette et al., 2006). Further, similar urban attributes may affect soil organic matter accumulation differently in different biomes. Urban soil organic matter studies conducted across a variety climates will help to clarify any regional or biome influences on the effects of urbanization. Specifically, matched studies of urban soil organic matter and suspected contributing factors, such as microbial biomass, activity and community structure and vegetation composition, will help to elucidate explicit effects of biomes.

Increasing global temperatures and $\mathrm{CO}_{2}$ concentrations have both direct and indirect effects on global stocks of soil organic matter (Pendall et al., 2004). Microbial 
respiration of previously unavailable substrates from thawing or drying soils and increased metabolic rates are likely to increase the rate of decomposition. Free air $\mathrm{CO}_{2}$ exchange experiments that included nitrogen treatments revealed increased turnover rates of $6.3 \%$ in topsoils and $4.7 \%$ in subsoils compared to controls (Leavitt et al., 2001). But, increases in net primary productivity (Norby et al., 2005), and, therefore, increased carbon inputs to soil are also expected. Observations of net primary productivity reflect agreement with predictions in some regions, but not in others. For example, in a tundra ecosystem, plant biomass increases with experimental warming do not alter plant community composition (Biasi et al., 2008) whereas in tropical climates, increases in temperature lead to changes in ecosystem structure, but not total carbon storage (Raich et al., 2006). As Crow et al. (2009) point out, even in ecosystems where net primary productivity increases in response to increased temperature, carbon balances will likely shift between vegetation and soil pools uniquely per ecosystem. Experimental evidence supports this hypothesis: in a field-warming study, composition of soil organic matter shifted from lignin-derived compounds to leaf-cuticle-derived compounds in temperate soils (Feng et al., 2008).

Urbanization and global climate change both disturb existing patterns of local temperature, precipitation, atmospheric $\mathrm{CO}_{2}$ and vegetation structure. But, despite circumstantial evidence that the change in genus composition in Portland may have buffered decreases in soil organic matter, vegetation appears divorced from soil organic matter in Portland. This disconnection is unlikely to result from global climate change in undisturbed ecosystems. Thus, though they are increasingly important ecosystems 
because they are growing in size and number, cities appear not to act as a surrogate model for changes in soil organic matter that might accompany global climate change.

These results emphasize the amount of work left to be done to understand the mechanisms of soil organic matter formation, disturbance and equilibrium in urban ecosystems. Several specific changes to the current strategic approach of urban soil organic matter studies would help to clarify the remaining issues. First, measurement of a wide variety of factors should be standard operating procedure when studying the urban environment because urban systems are dynamic and constraints on their biogeochemical cycles are relatively poorly understood. Further, studies should be undertaken in a greater number of cities across a variety of climates to allow researchers to determine which variables are important to soil organic matter accumulation universally and which might be regionally or locally influential. Additionally, results from urban soil organic matter studies conducted across a variety of scales will help to bring to light which human-related variables constrain soil organic matter in cities. Large- or small-scale urban variables that were not investigated here may link people and their behavior and consumption choices to soil organic matter. Most importantly, urban soil microbiota needs to be studied more thoroughly and methodically. Measurement of respiration, calculation of metabolic quotient and evaluation of community profiles should be variables in all future studies of soil organic matter. Making the effort to unify techniques and discuss and compare results will help urban ecologists overcome the challenges inherent to the study of biogeochemistry in a novel environment. 


\section{Tables}

Table 1. Summary of Vegetation Statistics for Downtown. Downtown-specific vegetation statistics (48 plots).

\begin{tabular}{|c|c|c|c|}
\hline & Mean & Mode & $\mathrm{SE}$ \\
\hline Fine Root Biomass (mg/g) & 5.609 & & 1.778 \\
\hline Stems/ha & 1021.400 & & 185.132 \\
\hline Trees/ha & 246.400 & & 27.880 \\
\hline Average DBH & 32.680 & & 3.113 \\
\hline Shrubs/ha & 261.800 & & 78.589 \\
\hline Evergreens/ha & 284.500 & & 57.177 \\
\hline Deciduous/ha & 218.900 & & 53.016 \\
\hline Conifers/ha & 21.070 & & 6.651 \\
\hline Dominant Functional Type & \multicolumn{3}{|c|}{ Deciduous Trees } \\
\hline Shannon Diversity Index & 1.030 & & 0.147 \\
\hline Most Abundant Genus & & Acer & \\
\hline Most Abundant Family & & Sapindaceae & \\
\hline Most Basal Area & & Acer & \\
\hline Average Basal Area $\left(\mathrm{m}^{2}\right)$ & 1.867 & & 0.193 \\
\hline Greatest Importance Value & & Acer & \\
\hline
\end{tabular}

Table 2. Summary of Vegetation Statistics for Lloyd District. Lloyd District-specific vegetation statistics (34 plots).

\begin{tabular}{|c|c|c|c|}
\hline Fine Root Biomass (mg/g) & $\begin{array}{l}\text { Mean } \\
9.7427\end{array}$ & Mode & $\begin{array}{l}\mathrm{SE} \\
1.280\end{array}$ \\
\hline Stems/ha & 512.700 & & 29.137 \\
\hline Trees/ha & 263.200 & & 34.645 \\
\hline Average DBH & 31.790 & & 0.287 \\
\hline Shrubs/ha & 250.600 & & 15.074 \\
\hline Evergreens/ha & 235.756 & & 40.814 \\
\hline Deciduous/ha & 219.700 & & 15.252 \\
\hline Conifers/ha & 34.330 & & 29.597 \\
\hline Dominant Functional Type & & Evergreens & \\
\hline Shannon Diversity Index & 0.983 & & 0.057 \\
\hline Most Abundant Genus & & Acer & \\
\hline Most Abundant Family & & Sapindaceae & \\
\hline Most Basal Area & & Acer & \\
\hline Average Basal Area $\left(\mathrm{m}^{2}\right)$ & & & 0.057 \\
\hline Greatest Importance Value & & Acer & \\
\hline
\end{tabular}


Table 3. Summary of Vegetation Statistics for Gateway. Gateway-specific vegetation statistics (19 plots).

\begin{tabular}{|c|c|c|c|}
\hline & Mean & Mode & $\mathrm{SE}$ \\
\hline Fine Root Biomass (mg/g) & 8.800 & & 1.087 \\
\hline Stems/ha & 1187.800 & & 195.475 \\
\hline Trees/ha & 383.000 & & 49.307 \\
\hline Average DBH & 21.670 & & 3.008 \\
\hline Shrubs/ha & 813.000 & & 176.527 \\
\hline Evergreens/ha & 829.400 & & 193.685 \\
\hline Deciduous/ha & 366.600 & & 58.350 \\
\hline Conifers/ha & 239.600 & & 54.319 \\
\hline Dominant Functional Type & & Evergreens & \\
\hline Shannon Diversity Index & 1.389 & & 0.112 \\
\hline Most Abundant Genus & & Pseudotsuga & \\
\hline Most Abundant Family & & Cupressaceae & \\
\hline Most Basal Area & & Acer & \\
\hline Average Basal Area $\left(\mathrm{m}^{2}\right)$ & 0.864 & & 0.103 \\
\hline Greatest Importance Value & & Acer & \\
\hline
\end{tabular}

Table 4. Summary of Vegetation Statistics for Lents. Lents-specific vegetation statistics (53 plots). *Median fine root biomass in Lents is $5.569 \mathrm{mg} / \mathrm{g}$, the Lents Fine Root Biomass distribution suffers from four distant outliers.

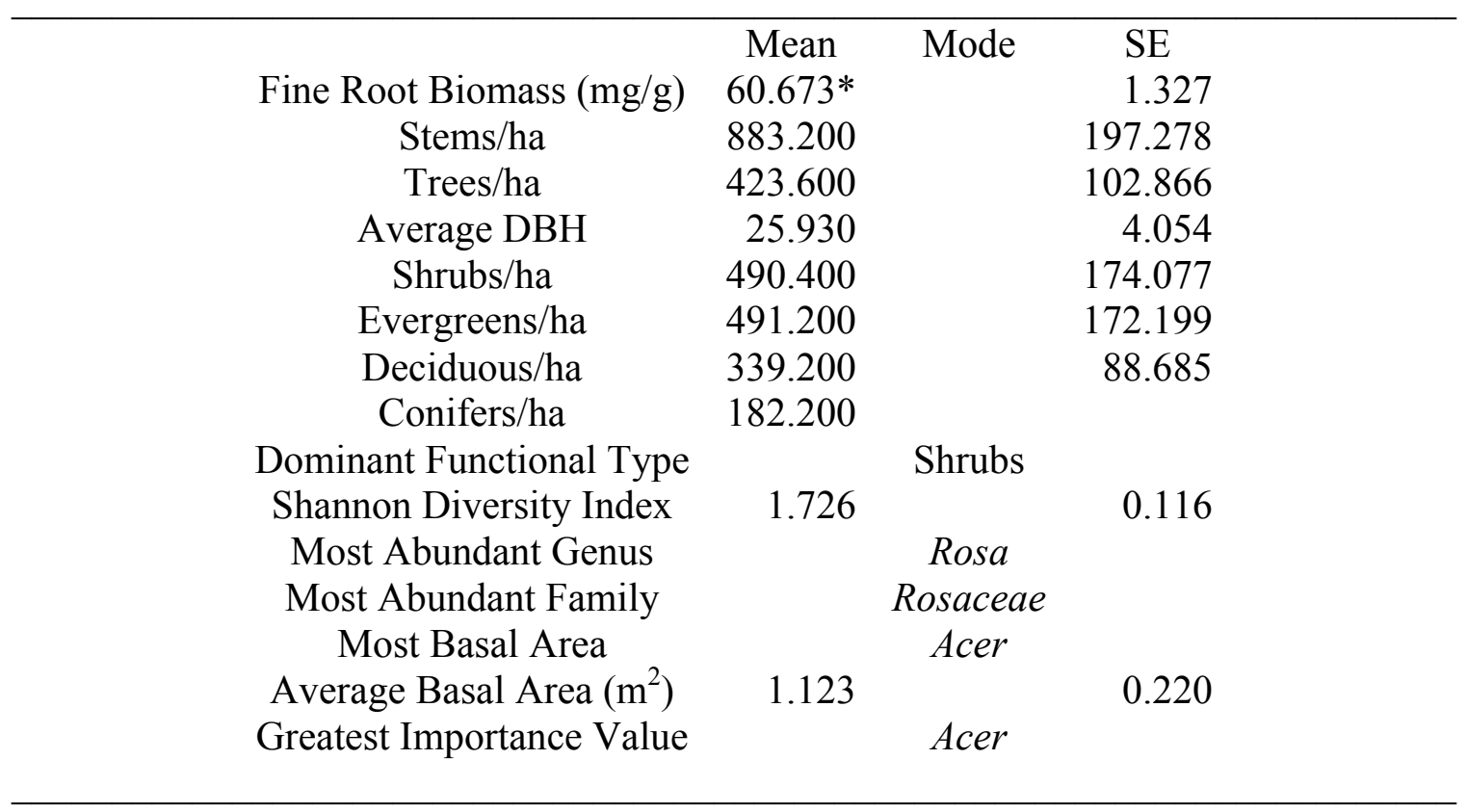


Table 5. Summary of Vegetation Statistics for Portland. Means and modes are averages and counts across all EcoDistricts (154 plots).

\begin{tabular}{|c|c|c|c|}
\hline & Mean & Mode & $\mathrm{SE}$ \\
\hline Fine Root Biomass (mg/g) & 25.866 & & 20.215 \\
\hline Stems/ha & 882.056 & & 124.882 \\
\hline Trees/ha & 328.000 & & 48.827 \\
\hline Average DBH & 28.800 & & \\
\hline Shrubs/ha & 406.000 & & 93.687 \\
\hline Evergreens/ha & 412.100 & & 87.576 \\
\hline Deciduous/ha & 278.700 & & 49.875 \\
\hline Conifers/ha & 106.400 & & 37.962 \\
\hline Dominant Functional Type & \multicolumn{3}{|c|}{ Evergreens } \\
\hline Shannon Diversity Index & 1.303 & & 0.110 \\
\hline Most Abundant Genus & & Acer & \\
\hline Most Abundant Family & & Rosaceae & \\
\hline Average Basal Area $\left(\mathrm{m}^{2}\right)$ & 1.253 & & 0.252 \\
\hline Most Basal Area & & Acer & \\
\hline Greatest Importance Value & & Acer & \\
\hline
\end{tabular}

Table 6. Summary Soil Statistics for Downtown. Downtown-specific soil statistics (48 plots).

\begin{tabular}{crrr}
\hline & Mean & Mode & SE \\
Soil Organic Matter $(\mathrm{g} / \mathrm{kg})$ & 128.280 & & 22.608 \\
Total Carbon $(\mathrm{g} / \mathrm{kg})$ & 49.929 & 7.054 \\
Total Nitrogen $(\mathrm{g} / \mathrm{kg})$ & 2.596 & 0.329 \\
C:N Ratio & 20.259 & 1.453 \\
Bulk Density $(\mathrm{g} / \mathrm{cm} 3)$ & 0.636 & 0.051 \\
Microbial Biomass $(\mu \mathrm{g} / \mathrm{g})$ & 94.969 & 23.012 \\
Texture & \multicolumn{2}{c}{ Coarse Loamy Sand } \\
Clay Content & 21.712 & & 2.739 \\
\hline
\end{tabular}


Table 7. Summary Soil Statistics for Lloyd District. Lloyd District-specific soil statistics (34 plots).

\begin{tabular}{crcc}
\hline & Mean & Mode & SE \\
Soil Organic Matter $(\mathrm{g} / \mathrm{kg})$ & 85.729 & 6.344 \\
Total Carbon $(\mathrm{g} / \mathrm{kg})$ & 46.049 & 3.106 \\
Total Nitrogen $(\mathrm{g} / \mathrm{kg})$ & 2.638 & 0.197 \\
C:N Ratio & 17.899 & 0.477 \\
Bulk Density $(\mathrm{g} / \mathrm{cm} 3)$ & 0.478 & 0.048 \\
Microbial Biomass $(\mu \mathrm{g} / \mathrm{g})$ & 36.275 & 7.191 \\
Texture & & Coarse Loamy Sand & 0.000 \\
Clay Content & 10.500 & &
\end{tabular}

Table 8. Summary Soil Statistics for Gateway. Gateway-specific soil statistics (19 plots).

\begin{tabular}{crcc}
\hline & \multicolumn{1}{c}{ Mean } & Mode & SE \\
Soil Organic Matter $(\mathrm{g} / \mathrm{kg})$ & 77.521 & 4.916 \\
Total Carbon $(\mathrm{g} / \mathrm{kg})$ & 36.833 & 3.258 \\
Total Nitrogen $(\mathrm{g} / \mathrm{kg})$ & 2.798 & 0.256 \\
C:N Ratio & 13.205 & 0.179 \\
Bulk Density $(\mathrm{g} / \mathrm{cm} 3)$ & 0.636 & 0.044 \\
Microbial Biomass $(\mu \mathrm{g} / \mathrm{g})$ & 67.395 & 6.096 \\
Texture & \multicolumn{2}{c}{ Fine Clay } & 3.871 \\
Clay Content & 56.833 & &
\end{tabular}

Table 9. Summary Soil Statistics for Lents. Lents-specific soil statistics (53 plots).

\begin{tabular}{crcc}
\hline Lents Soil & \multicolumn{1}{c}{ Mean } & Mode & SE \\
Soil Organic Matter $(\mathrm{g} / \mathrm{kg})$ & 95.412 & & 8.525 \\
Total Carbon $(\mathrm{g} / \mathrm{kg})$ & 42.223 & 5.654 \\
Total Nitrogen $(\mathrm{g} / \mathrm{kg})$ & 3.233 & 0.449 \\
C:N Ratio & 13.934 & 0.873 \\
Bulk Density $(\mathrm{g} / \mathrm{cm} 3)$ & 0.743 & 0.040 \\
Microbial Biomass $(\mu \mathrm{g} / \mathrm{g})$ & 52.978 & 8.796 \\
Texture & & Fine Silty Clay & 3.273 \\
Clay Content & 34.328 & & \\
\hline
\end{tabular}


Table 10. Summary of Soil Statistics for Portland. Means and modes are averages and counts across all EcoDistricts (154 plots).

\begin{tabular}{crcc}
\hline & Mean & Mode & SE \\
Total Carbon $(\mathrm{g} / \mathrm{kg})$ & 47.872 & & 3.524 \\
Total Nitrogen $(\mathrm{g} / \mathrm{kg})$ & 2.782 & & 0.143 \\
C:N Ratio & 17.096 & 0.595 \\
Bulk Density $(\mathrm{g} / \mathrm{cm} 3)$ & 0.711 & 0.023 \\
Microbial Biomass $(\mu \mathrm{g} / \mathrm{g})$ & 74.659 & 6.240 \\
Texture & & Coarse Loamy Sand & 1.583 \\
Clay Content & 30.214 & \\
\hline
\end{tabular}

Table 11. Summary of Urban Statistics for Downtown. Downtwon-specific urban statistics (48 plots).

\begin{tabular}{crrr}
\hline Zoning & Mean & $\begin{array}{c}\text { Mode } \\
\text { Central } \\
\text { Commercial }\end{array}$ & \multicolumn{1}{c}{ SE } \\
Impervious Surface (\%) & 70.920 & & 2.000 \\
Distance to Urban Center (km) & 1.094 & & 0.203 \\
Years Since Annexation & 124.000 & & 1.078 \\
Years Since Development & 50.940 & & 6.653 \\
Square Footage of Buildings on Adjacent Tax Lots & 70,059 & & 15,708 \\
Footprint of Buildings on Adjacent Tax Lots (acres) & 1.128 & 0.173 \\
Total Value of Adjacent Tax Lots & $\$ 10.45 \mathrm{M}$ & $\$ 2.03 \mathrm{M}$
\end{tabular}

Table 12. Summary of Urban Statistics for Lloyd District. Lloyd District-specific urban statistics (34 plots).

\begin{tabular}{|c|c|c|c|}
\hline Zoning & Mean & $\begin{array}{c}\text { Mode } \\
\text { Central } \\
\text { Commercial }\end{array}$ & SE \\
\hline Impervious Surface (\%) & 75.240 & & 1.975 \\
\hline Distance to Urban Center $(\mathrm{km})$ & 2.042 & & 0.064 \\
\hline Years Since Annexation & 101.200 & & 0.728 \\
\hline Years Since Development & 39.270 & & 2.699 \\
\hline Square Footage of Buildings on Adjacent Tax Lots & 75,863 & & 23,401 \\
\hline Footprint of Buildings on Adjacent Tax Lots (acres) & 2.058 & & 0.511 \\
\hline Total Value of Adjacent Tax Lots & $\$ 17.57 \mathrm{M}$ & & $\$ 6.64 \mathrm{M}$ \\
\hline
\end{tabular}


Table 13. Summary of Urban Statistics for Gateway. Gateway-specific urban statistics (19 plots).

\begin{tabular}{|c|c|c|c|}
\hline Zoning & Mean & $\begin{array}{c}\text { Mode } \\
\text { Central } \\
\text { Commercial / } \\
\text { Institutional } \\
\text { Residential }\end{array}$ & SE \\
\hline Impervious Surface (\%) & 60.760 & & 2.597 \\
\hline Distance to Urban Center $(\mathrm{km})$ & 9.397 & & 0.060 \\
\hline Years Since Annexation & 23.160 & & 1.442 \\
\hline Years Since Development & 43.800 & & 2.619 \\
\hline $\begin{array}{l}\text { Square Footage of Buildings on Adjacent Tax } \\
\text { Lots }\end{array}$ & 60,332 & & 21,319 \\
\hline $\begin{array}{l}\text { Footprint of Buildings on Adjacent Tax Lots } \\
\text { (acres) }\end{array}$ & 4.207 & & 0.902 \\
\hline Total Value of Adjacent Tax Lots & $\$ 13.47 \mathrm{M}$ & & $\$ 618,519$ \\
\hline
\end{tabular}

Table 14. Summary of Urban Statistics for Lents. Lents-specific urban statistics (53 plots).

\begin{tabular}{crrr}
\hline Zoning & Mean & Mode & \multicolumn{1}{c}{ SE } \\
Open Space & \\
Impervious Surface (\%) & 51.100 & & 2.125 \\
Distance to Urban Center (km) & 10.026 & & 87.821 \\
Years Since Annexation & 61.700 & 5.212 \\
Years Since Development & 53.440 & 3.979 \\
Square Footage of Buildings on Adjacent Tax Lots & 4,219 & 1,687 \\
Footprint of Buildings on Adjacent Tax Lots (acres) & 3.547 & 1.689 \\
Total Value of Adjacent Tax Lots & $\$ 660,684$ & \\
\hline
\end{tabular}


Table 15. Summary of Urban Statistics for Portland. Means and modes are averages and counts across all EcoDistricts (154 plots).

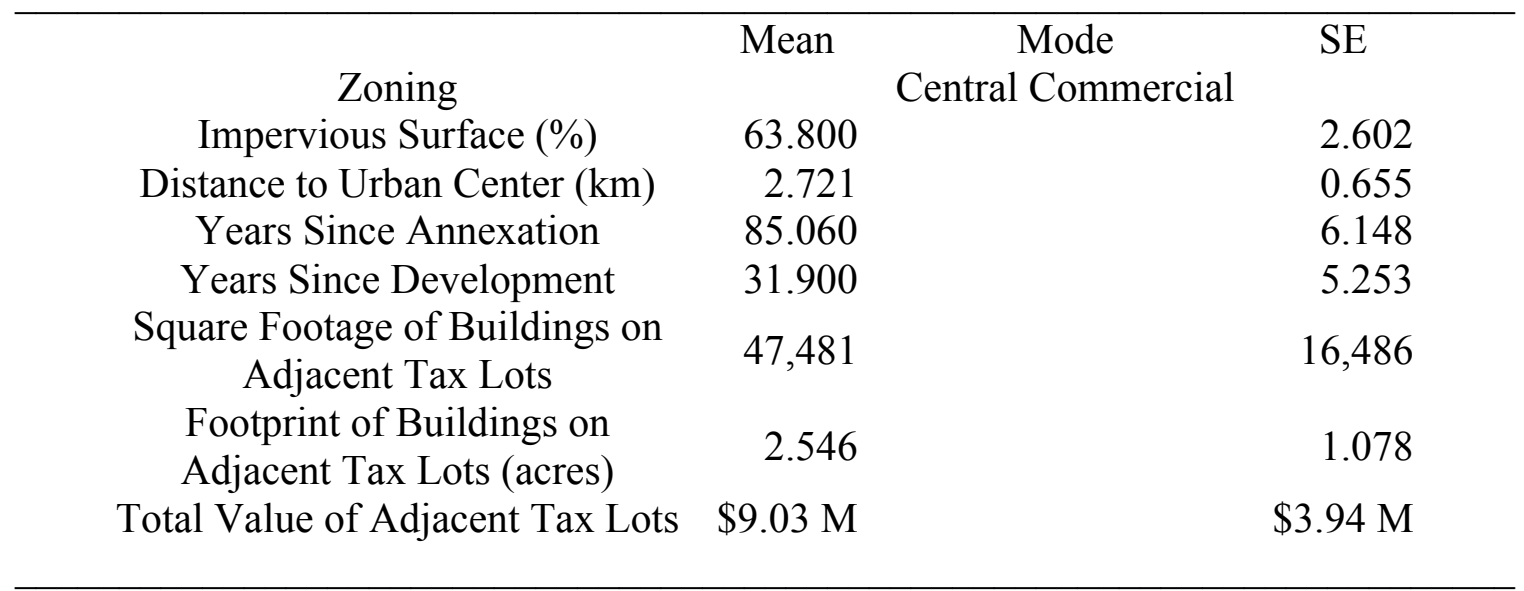

Table 16. Principal Components Loadings of Urban Variables for Portland. PCA loadings show that each urban variable governs its own principal axis; values represent fractions of axes composed of the variance of each variable.

\begin{tabular}{|c|c|c|c|c|c|c|c|}
\hline Portland PCA & $\mathrm{PC} 1$ & $\mathrm{PC} 2$ & PC3 & PC4 & PC5 & PC6 & PC7 \\
\hline Total Value of & 1.000 & & & & & & \\
\hline \multicolumn{8}{|l|}{ Adjacent Tax Lots } \\
\hline Years Since Annexation & & & 0.967 & -0.168 & 0.181 & & \\
\hline Distance to Urban Center & & & & & & & 0.994 \\
\hline Impervious Surface & & & 0.176 & & -0.978 & & \\
\hline $\begin{array}{l}\text { Square Footage of } \\
\text { Buildings on }\end{array}$ & & -1.000 & & & & & \\
\hline Adjacent Tax Lots & & & & & & & \\
\hline Years Since Development & & & -0.166 & -0.986 & & 0994 & \\
\hline Adjacent Tax Lots & & & & & & & \\
\hline
\end{tabular}


Table 17. Summary of Regression Analysis for Downtown. Soil organic matter in the Downtown EcoDistrict can be estimated from total carbon, total nitrogen and $\mathrm{C}: \mathrm{N}$ ratio. Note that the intercept does not significantly contribute to the Downtown model, but is retained to limit the significant variables.

\begin{tabular}{ccccc}
\hline & Estimate & SE & t-value & P-value \\
Intercept & -63.360 & 48.930 & -1.295 & 0.202 \\
$\log$ (Total Carbon $(\mathrm{g} / \mathrm{kg}))$ & -234.580 & 43.120 & 5.440 & $2.230 \times 10^{-6}$ \\
$\log ($ Total Nitrogen $(\mathrm{g} / \mathrm{kg}))$ & 516.730 & 69.120 & 7.475 & $2.310 \times 10^{-9}$ \\
sqrt(C:N Ratio) & 98.070 & 21.590 & 4.543 & $4.290 \times 10^{-5}$ \\
& & & & \\
\hline
\end{tabular}

Table 18. Summary of Regression Analysis for Lloyd District. Soil organic matter in the Lloyd District EcoDistrict can be estimated only by measuring several variables, including soil, vegetation and urban parameters. Note that all variables significantly contribute to the Lloyd model.

\begin{tabular}{crrrc}
\hline & Estimate & \multicolumn{1}{c}{ SE } & t-value & P-value \\
Intercept & 13400.864 & 3767.269 & 3.557 & $1.677 \times 10^{-3}$ \\
$\log ($ Total Carbon $(\mathrm{g} / \mathrm{kg}))$ & -617.270 & 135.575 & -4.553 & $1.420 \times 10^{-4}$ \\
$\log ($ Total Nitrogen $(\mathrm{g} / \mathrm{kg}))$ & 928.345 & 179.804 & 5.163 & $3.120 \times 10^{-5}$ \\
sqrt $(\mathrm{C}:$ N Ratio) & 314.006 & 60.524 & 5.188 & $2.930 \times 10^{-5}$ \\
Shannon Diversity Index & -36.808 & 9.822 & -3.747 & $1.051 \times 10^{-3}$ \\
Impervious Surface $(\%)$ & -1.720 & 0.538 & -3.195 & $4.030 \times 10^{-3}$ \\
$\log ($ Total Value of Adjacent Tax Lots) & 4.370 & 1.360 & 3.214 & $3.843 \times 10^{-3}$ \\
$\log ($ Day of Year Sampled) & -2312.449 & 649.331 & -3.561 & $1.660 \times 10^{-3}$ \\
Soil Temperature $\left({ }^{\circ} \mathrm{C}\right)$ & -8.923 & 3.825 & -2.333 & $2.876 \times 10^{-2}$ \\
Bulk Density $\left(\mathrm{g} / \mathrm{cm}^{3}\right)$ & -98.934 & 30.186 & -3.277 & $3.305 \times 10^{-3}$ \\
Soil Moisture $(\%)$ & 3.503 & 0.997 & 3.515 & $1.859 \times 10^{-3}$ \\
& & & & \\
\hline
\end{tabular}


Table 19. Summary of Regression Analysis for Gateway. Soil organic matter in the Gateway EcoDistrict can be estimated from C:N ratio and Conifers/ha. Note that the Conifers/ha term does not significantly contribute to the Gateway model, but is retained to limit the significant variables.

\begin{tabular}{crrrc} 
& Estimate & \multicolumn{1}{c}{$\mathrm{SE}$} & t-value & P-value \\
Intercept & -384.266 & 43.073 & -8.921 & $1.310 \times 10^{-7}$ \\
sqrt(C:N Ratio) & 117.970 & 10.504 & 11.230 & $5.340 \times 10^{-9}$ \\
sqrt(Conifers/ha) & 0.979 & 0.984 & 0.995 & 0.335
\end{tabular}

Table 20. Summary of Regression Analysis for Lents. Soil organic matter in the Lents EcoDistrict can be estimated from total nitrogen, C:N ratio and Trees/ha. Note that the Trees/ha term does not significantly contribute to the Lents model, but is retained to limit the significant variables.

$\begin{array}{crrrc} & \text { Estimate } & \text { SE } & \text { t-value } & \text { P-value } \\ \text { Intercept } & -154.948 & 20.825 & -7.441 & 1.380 \times 10^{-9} \\ \log (\text { Total Nitrogen }(\mathrm{g} / \mathrm{kg})) & 88.980 & 5.721 & 15.552 & 2.000 \times 10^{-16} \\ \text { sqrt(C:N Ratio) } & 35.611 & 4.200 & 8.479 & 3.570 \times 10^{-11} \\ \text { sqrt(Trees/ha) } & -0.205 & 0.260 & -0.788 & 0.434\end{array}$

Table 21. Summary of Regression Analysis for Portland. Soil organic matter in the Portland can be estimated from total carbon, total nitrogen, microbial biomass and bulk density.

\begin{tabular}{crrrr}
\hline & Estimate & \multicolumn{1}{c}{ SE } & \multicolumn{1}{c}{ t-value } & \multicolumn{1}{c}{ P-Value } \\
$\log ($ Total Nitrogen $(\mathrm{g} / \mathrm{kg}))$ & 98.293 & 27.183 & 3.616 & $6.140 \times 10^{-4}$ \\
$\log ($ Microbial Biomass $(\mu \mathrm{g} / \mathrm{g}))$ & 23.302 & 7.397 & 3.150 & $2.544 \times 10^{-3}$ \\
Bulk Density $\left(\mathrm{g} / \mathrm{cm}^{3}\right)$ & -109.443 & 33.442 & -3.273 & $1.77 \times 10^{-3}$ \\
& & & & \\
\hline
\end{tabular}


Table 22. Publications Used to Compare Portland to Pacific Northwest Soil Organic Carbon. Where necessary, reported bulk density was used to convert between $\mathrm{Mg} / \mathrm{ha}$ and $\mathrm{g} / \mathrm{kg}$. Only data from samples taken from the A horizon or superficial $30 \mathrm{~cm}$ were used. Soil organic carbon is calculated as $50 \%$ of SOM for use in comparison to studies that do not report loss-on-ignition (SOM).

$\begin{array}{crcc}\text { Author } & \text { SOC (Mg/ha) } & \text { Year } & \text { Location } \\ \text { Griffiths et al } & 893 & 1998 & \text { HJA } \\ \text { Homann } & 720 & 2007 & \text { OR Coast } \\ \text { Griffiths et al } & 691 & 1994 & \text { HJA } \\ \text { Homann } & 559 & 2005 & \text { WA Coast } \\ \text { Homann } & 291 & 2007 & \text { OR Cascades } \\ \text { Sun et al } & 267 & 2004 & \text { Lookout Mt WA } \\ \text { Homann } & 256 & 2005 & \text { WA Cascades } \\ \text { Sun et al } & 247 & 2004 & \text { Mt. Jefferson } \\ \text { Sun et al } & 229 & 2004 & \text { Mill City S } \\ \text { Sun et al } & 201 & 2004 & \text { Battle Ax, OR } \\ \text { Klopatek } & 175 & 2002 & \text { WRCCRF } \\ \text { Klopatek } & 157 & 2002 & \text { WRCCRF } \\ \text { Sun et al } & 154 & 2004 & \text { Breitenbush } \\ \text { Sun et al } & 142 & 2004 & \text { HJA } \\ \text { Adams } & 105 & 2005 & \text { Eastern WA } \\ \text { Klopatek } & 97 & 2002 & \text { WRCCRF } \\ \text { Adams } & 35 & 2005 & \text { Eastern WA }\end{array}$

Table 23. Comparison of Pacific Northwest Forest Soils to Portland Soils. Fewer, smaller trees, drier soils and less soil microbial biomass in Portland yields a comparable quantity of soil organic matter.

Stem Density (trees/ha)

Mean DBH $(\mathrm{cm})$ Average Annual Precipitation (cm)

Microbial Biomass $(\mu \mathrm{g} / \mathrm{g})$
Pacific Northwest Forest Soils

$\begin{array}{rr}519.8^{1} & 339.0 \\ 33.9^{1} & 28.5 \\ 253.0^{1} & 91.5^{2} \\ 500.0^{3} & 69.6\end{array}$

1 North et al., 2005

2 NOAA, 2011

3 Chaer et al., 2009 
Figures

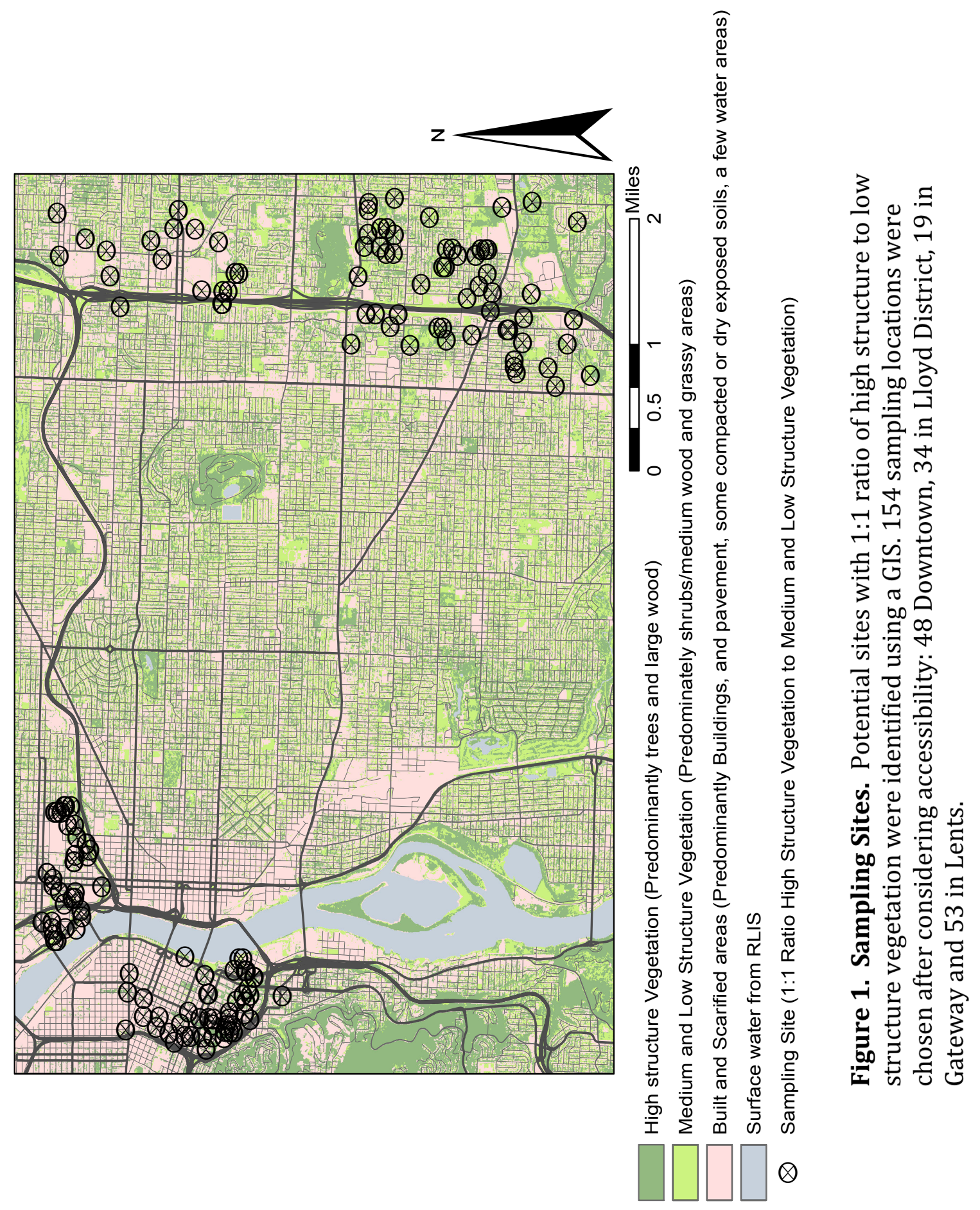




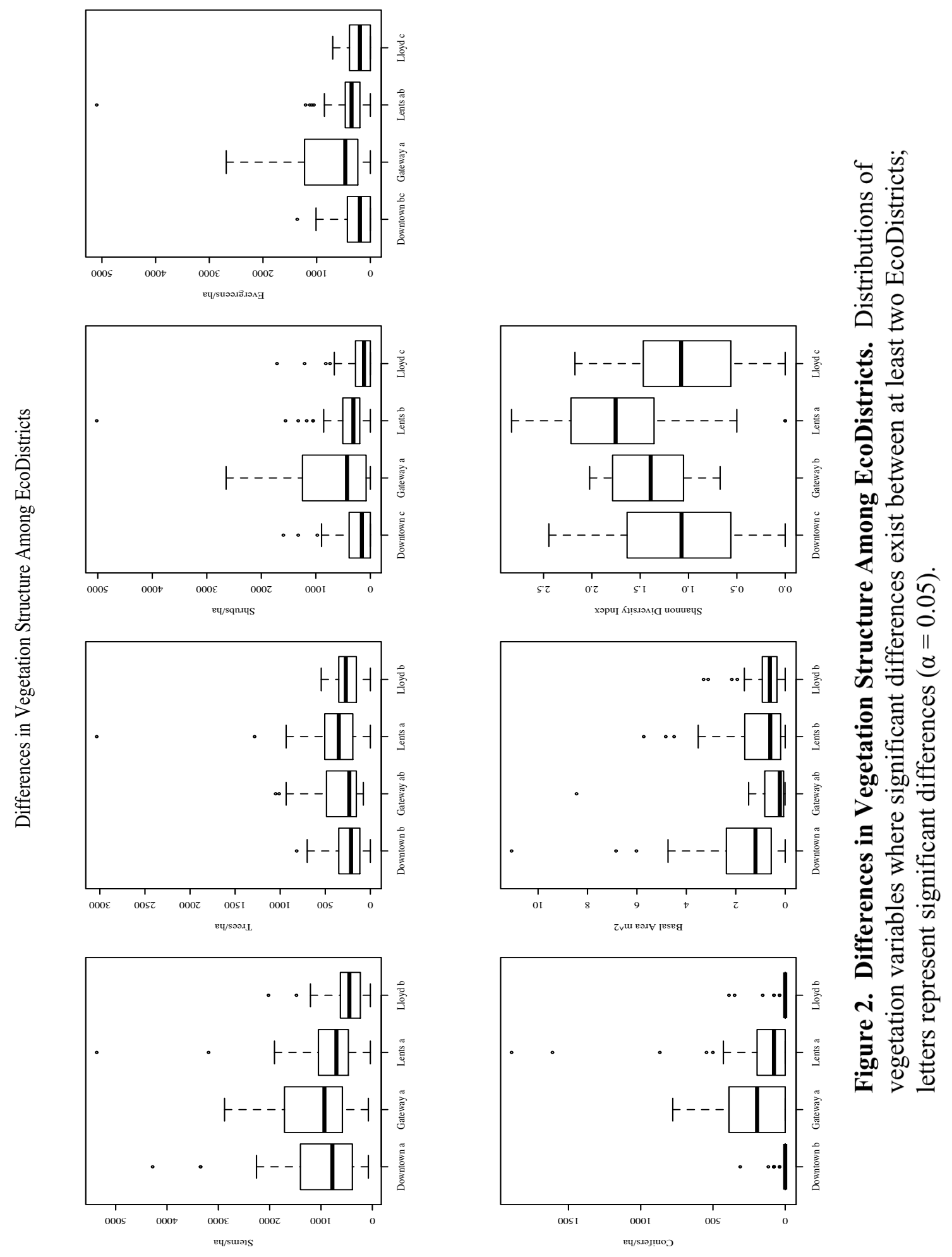




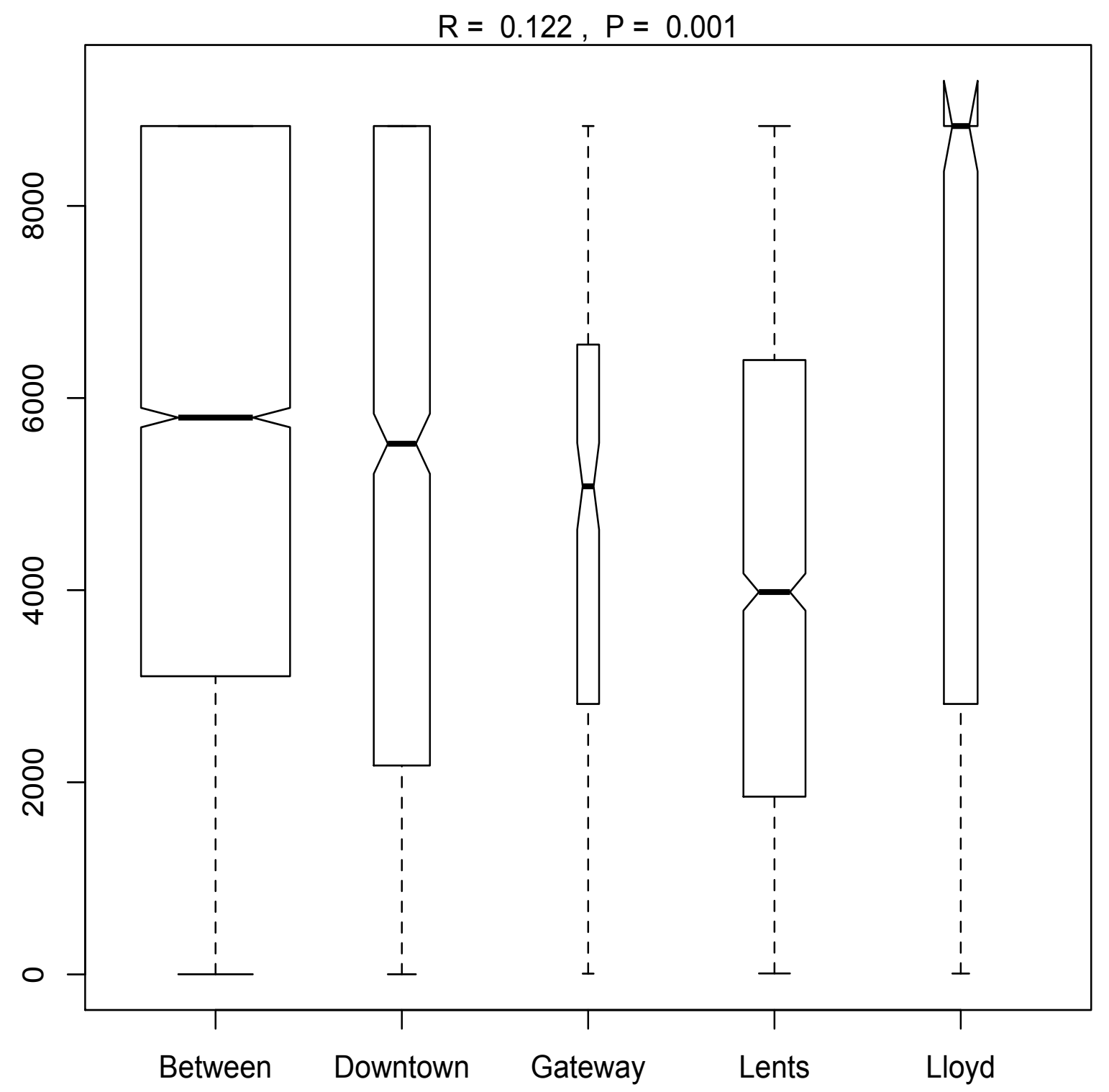

Figure 3. ANOSIM of Bray-Curtis Distance Among EcoDistricts. Analysis of Similarity shows that significant differences in plant community composition exist for at least two EcoDistricts. ANOSIM between each pair of Ecodistricts demonstrates that significant differences exist between Downtown and Lents and Lloyd District and Lents $(\alpha=0.05)$; where notches do not overlap, statistically significant differences exist between medians. 


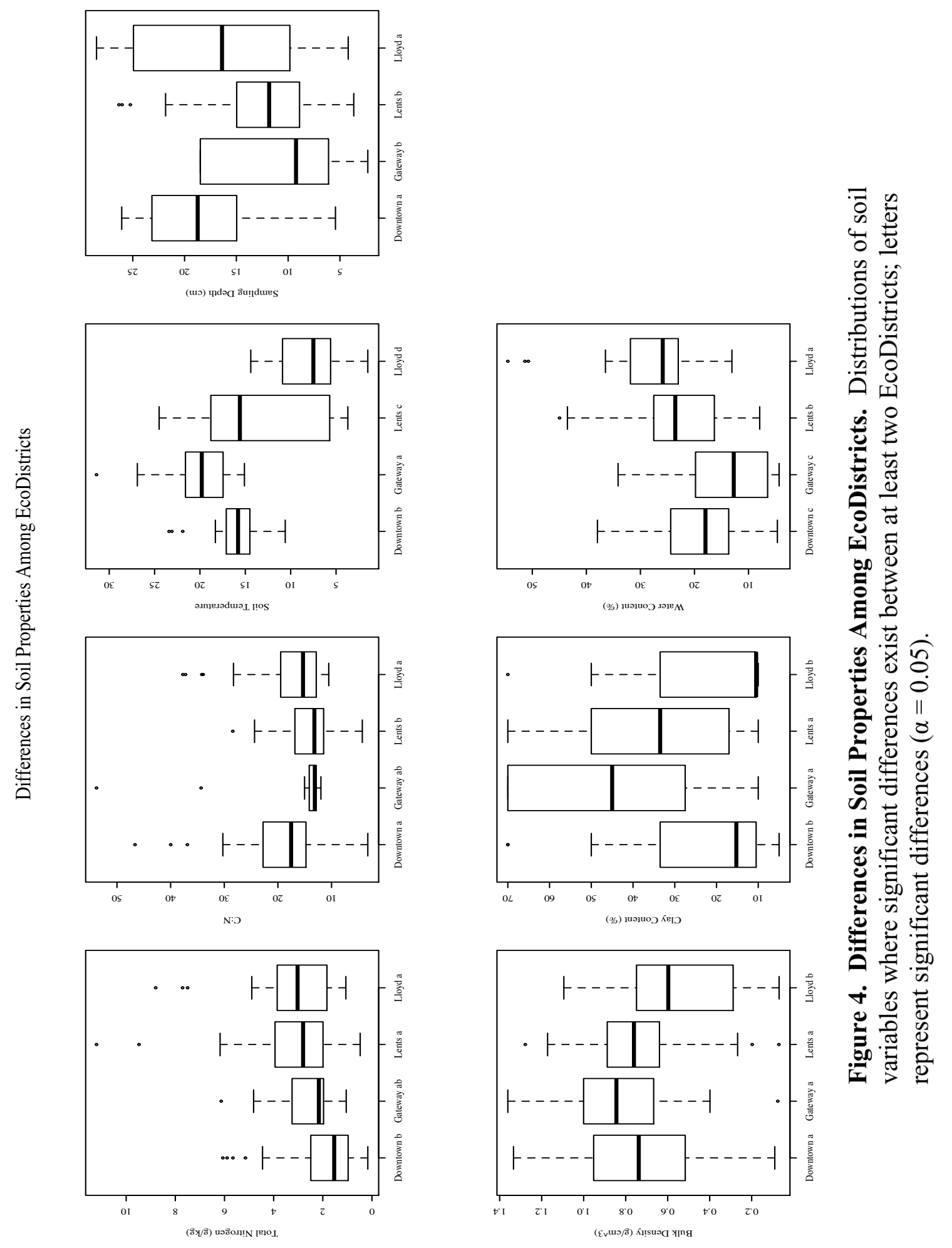




\section{Differences in SOM Among EcoDistricts}

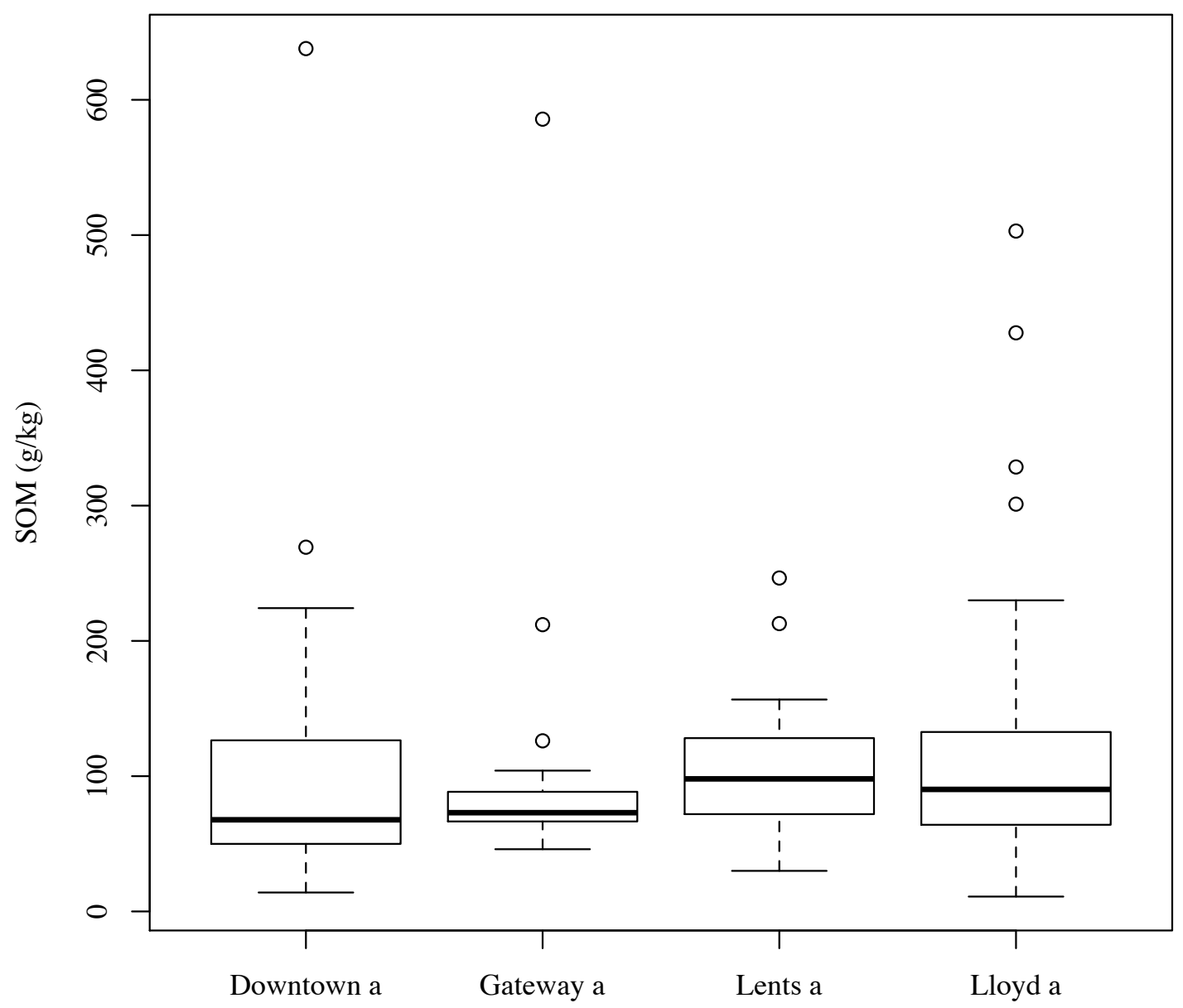

Figure 5. Soil Organic Matter Among EcoDistricts. Distributions of soil organic matter in each EcoDistrict. No significant differences were found $(\alpha=0.05)$. 


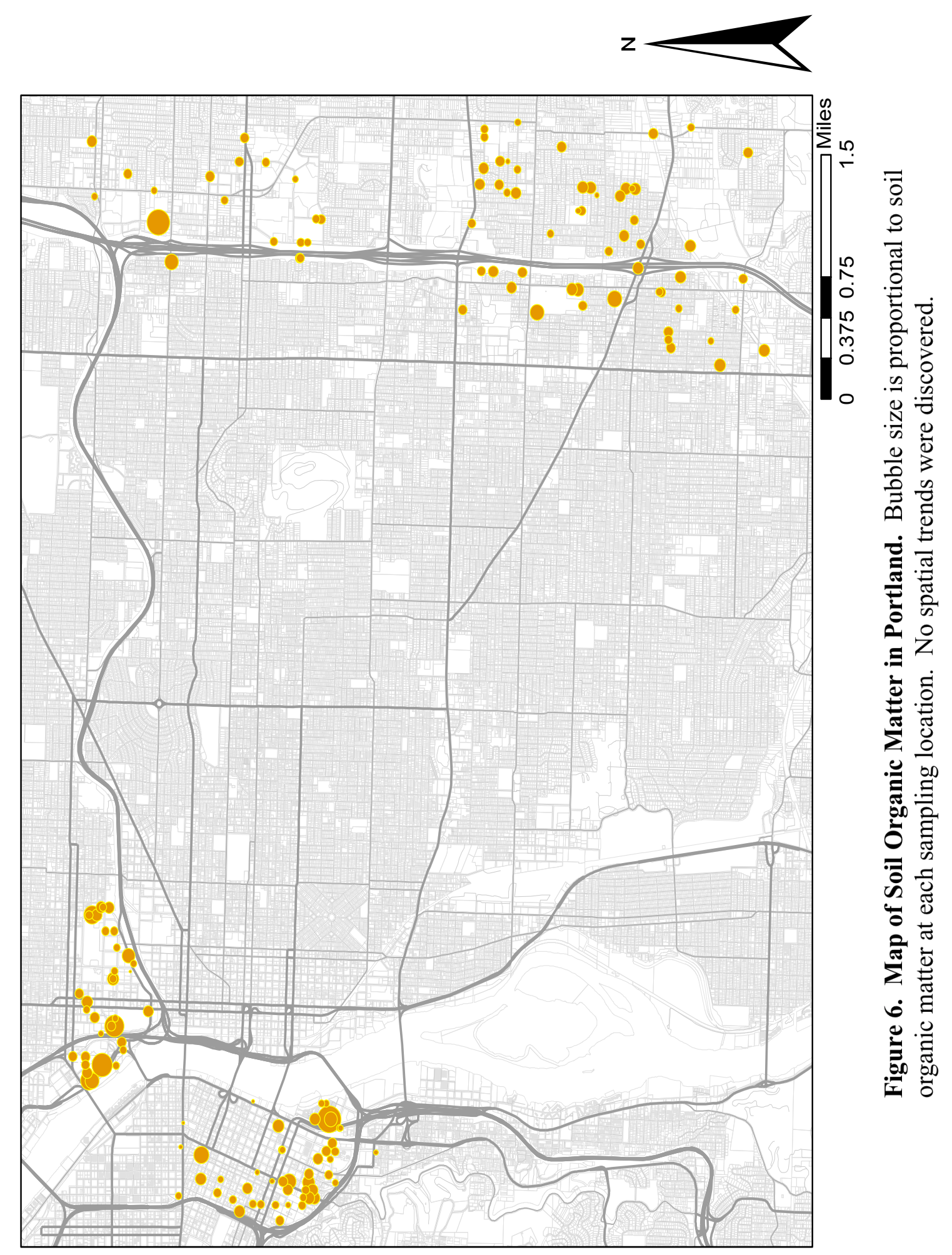




\section{Distribution of SOM in Portland}

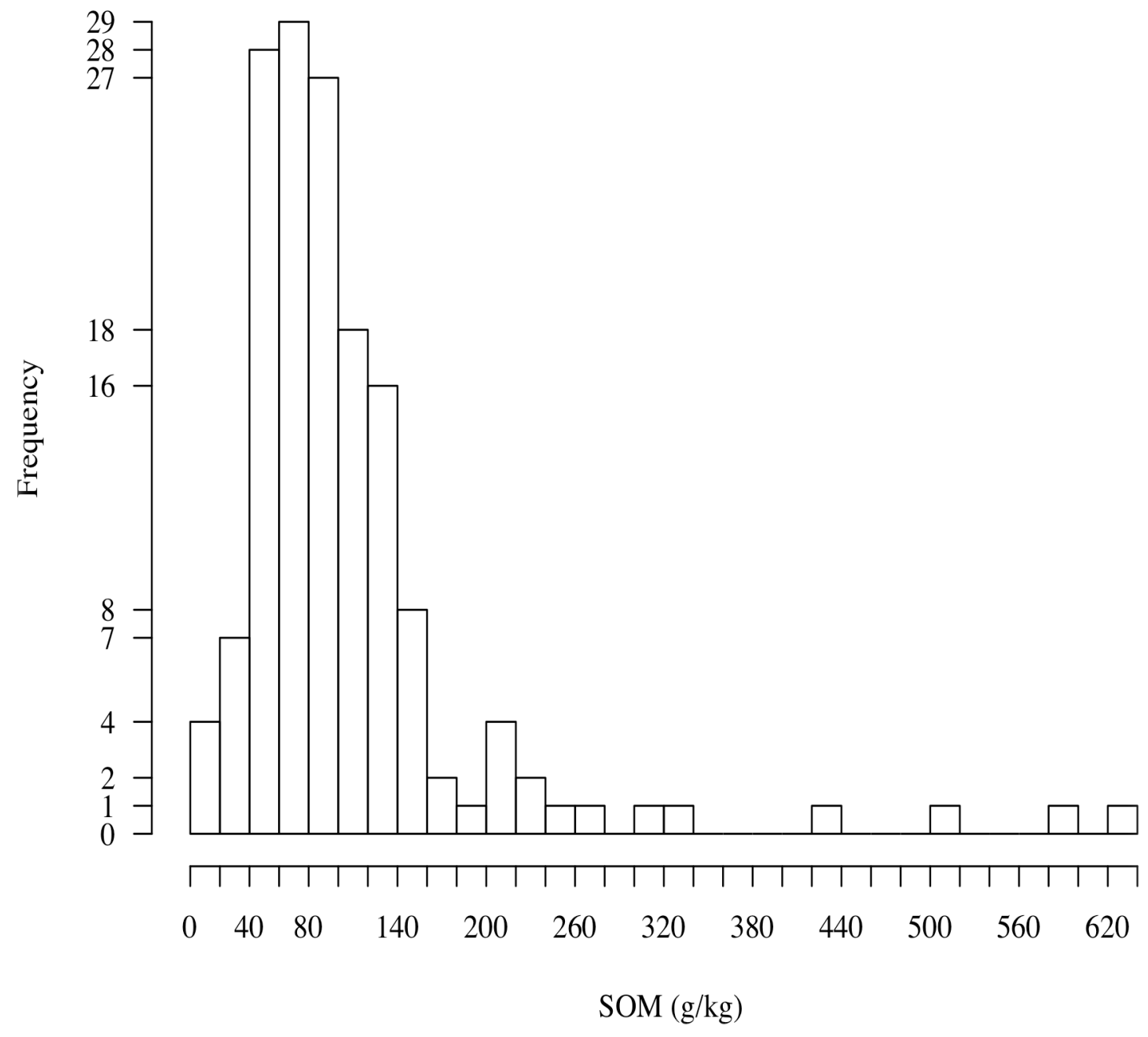

Figure 7. Distribution of Soil Organic Matter in Portland. The distribution is normal with a slight right tail; bins were selected using the Freedman-Diaconis rule. 
Differences in Urban Character Among EcoDistricts
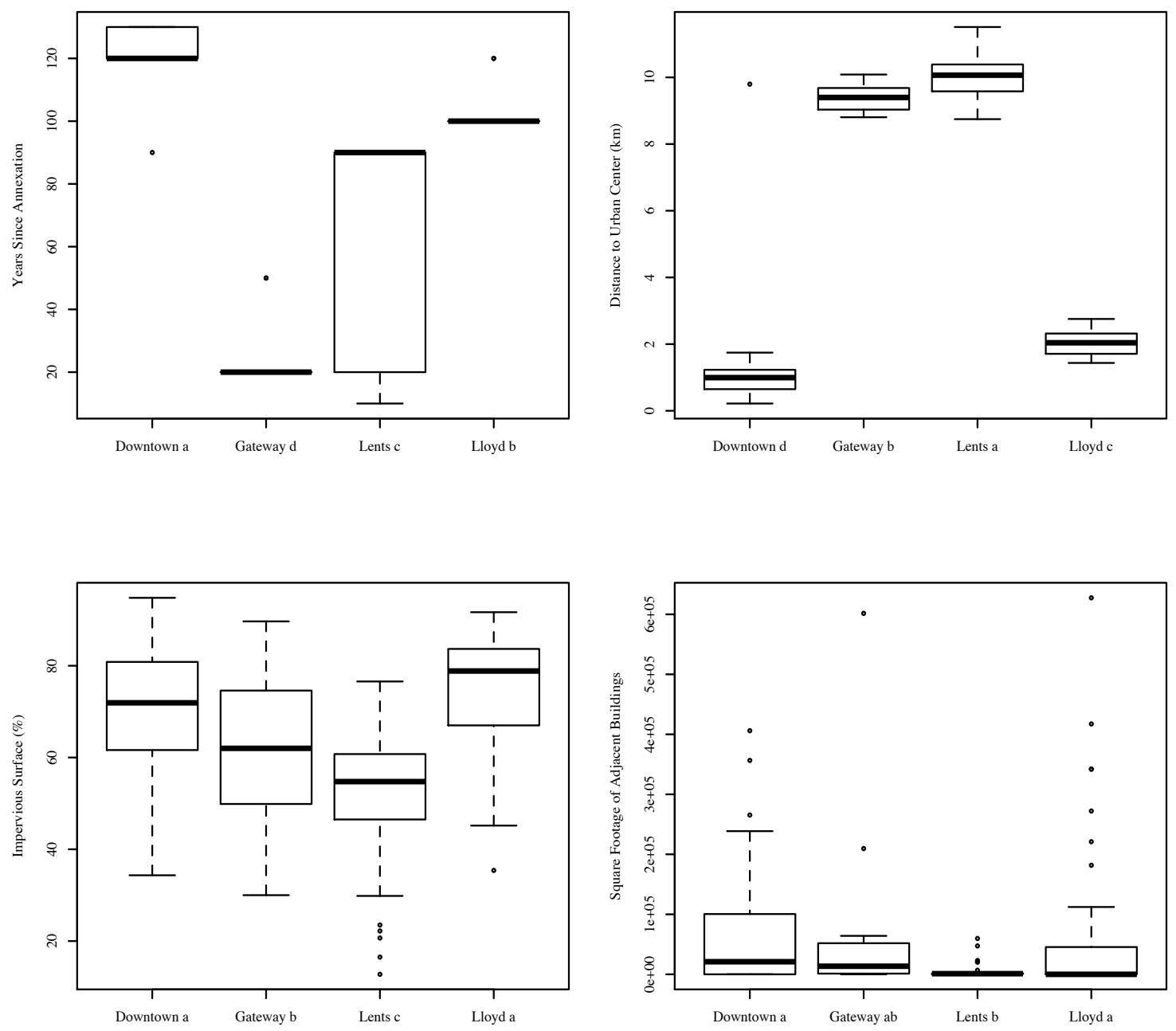

Figure 8. Differences in Urban Characteristics Among EcoDistricts. Distributions of urban variables where significant differences exist between at least two EcoDistricts; letters represent significant differences $(\alpha=0.05)$. 


\section{Portland}

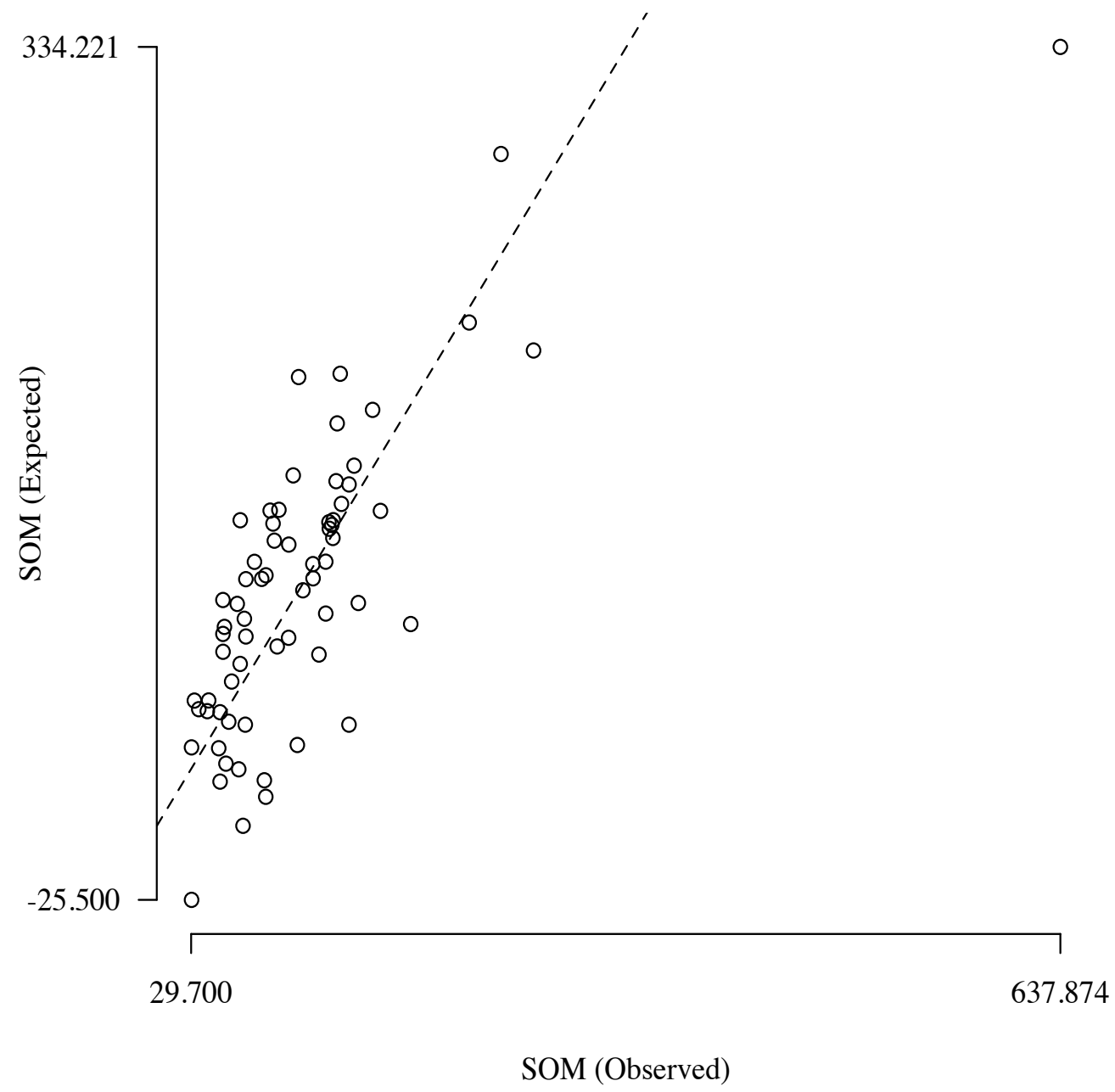

Figure 9. Expected vs. Observed Soil Organic Matter Values for Portland. The regression model for Portland (Table 21, Equation 5) was used to generate expected soil organic matter values, which were plotted against observed values. Minima and maxima are displayed; dashed line is $1: 1$. 


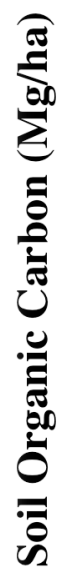

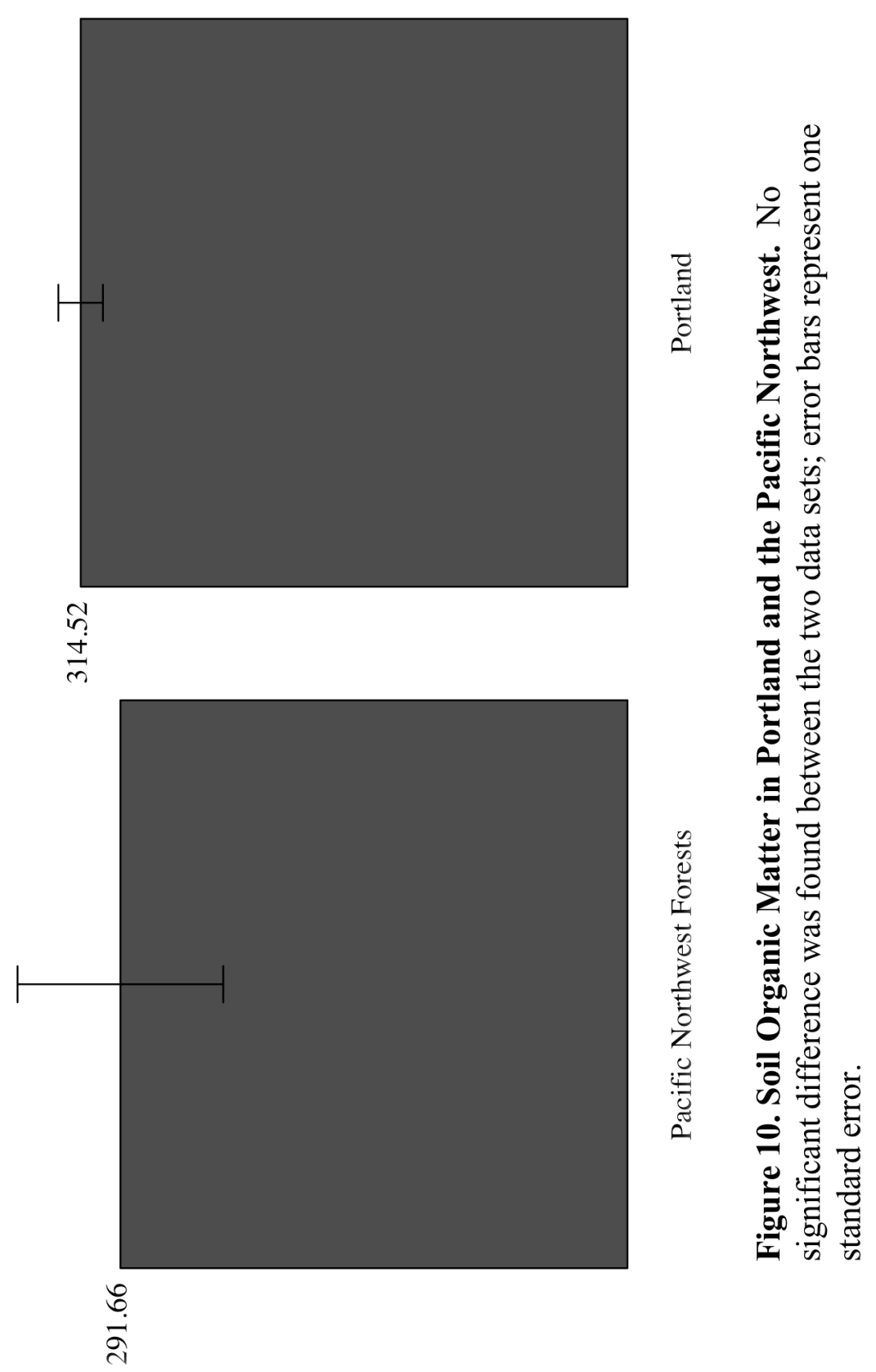




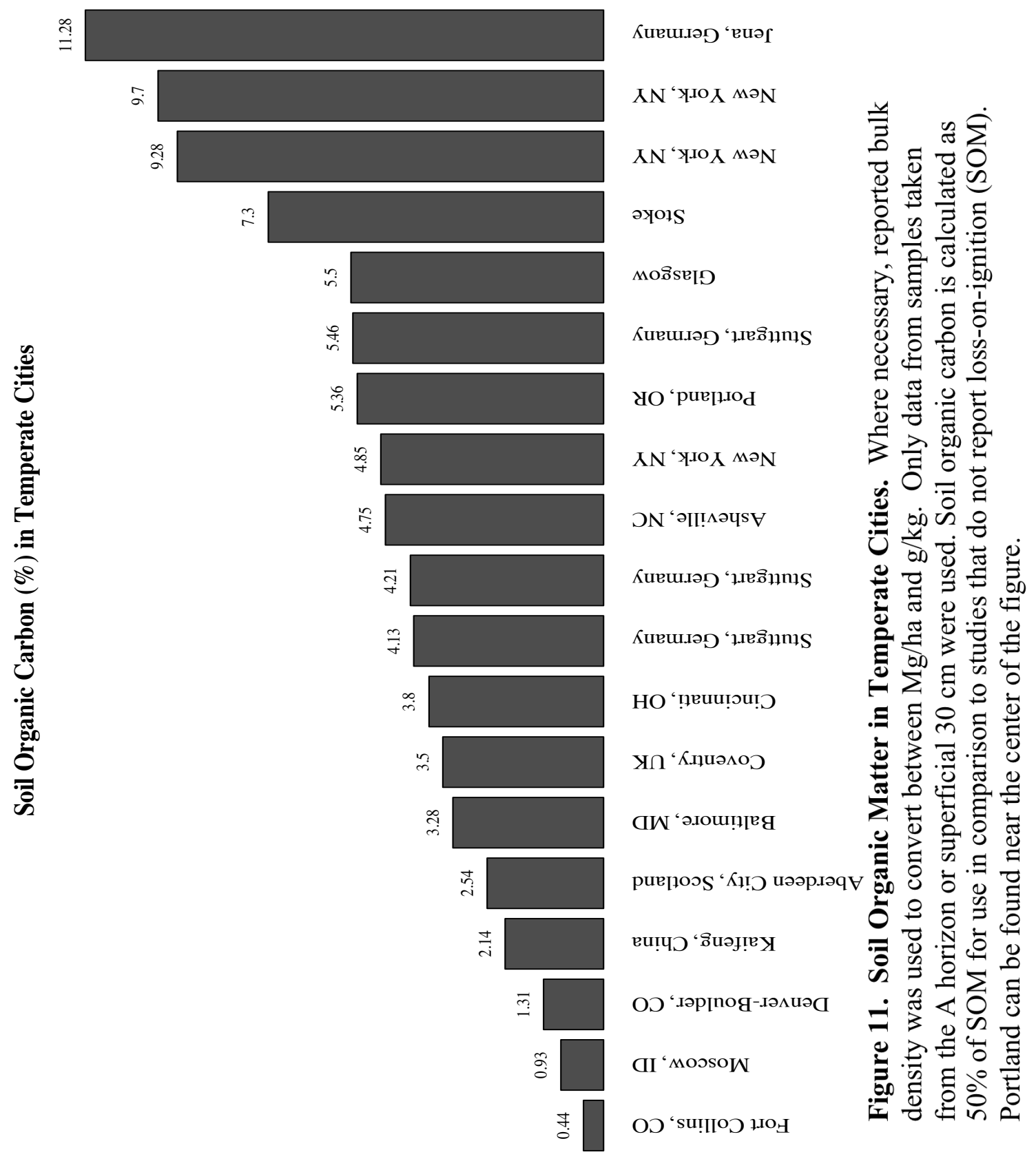




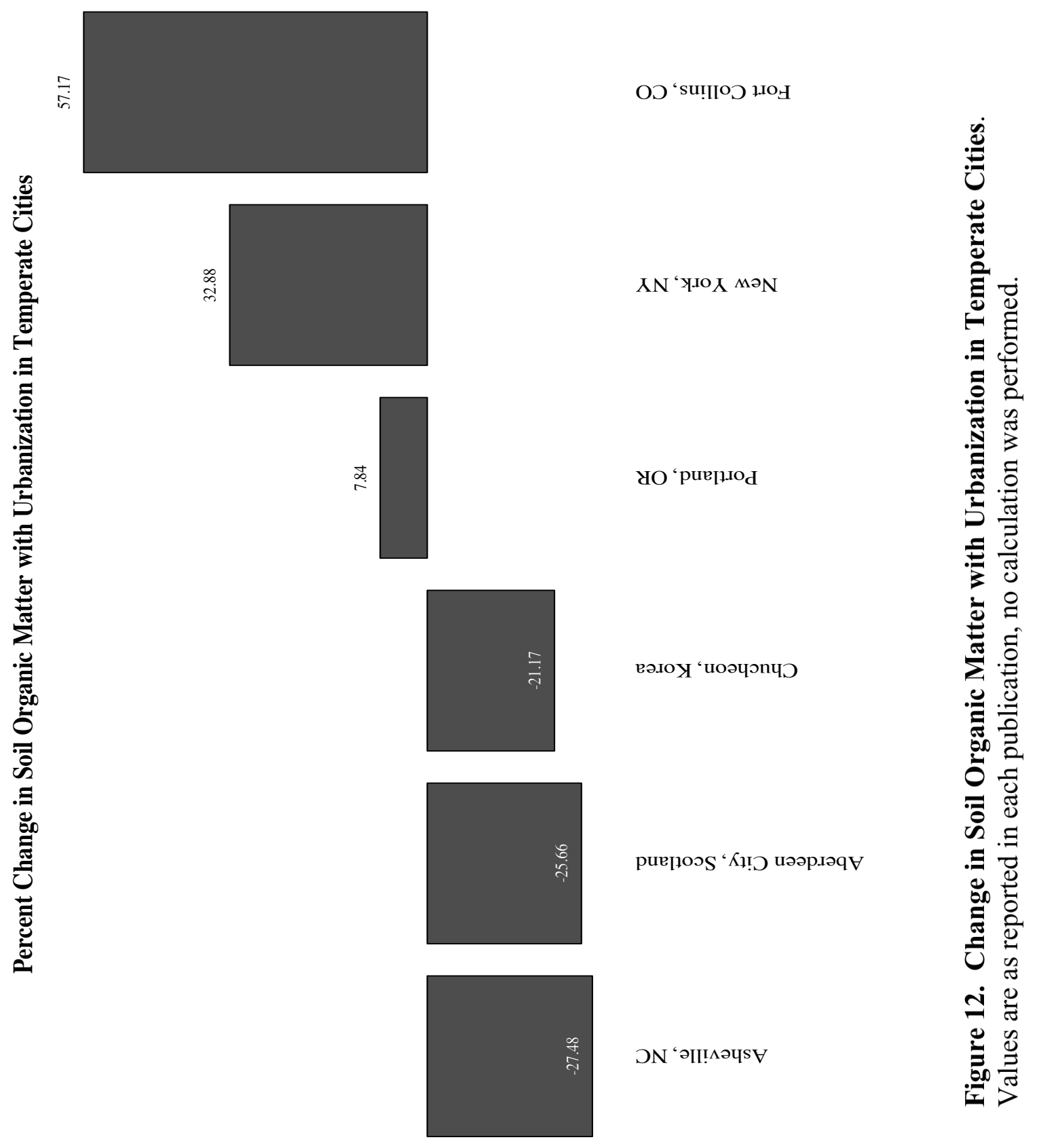




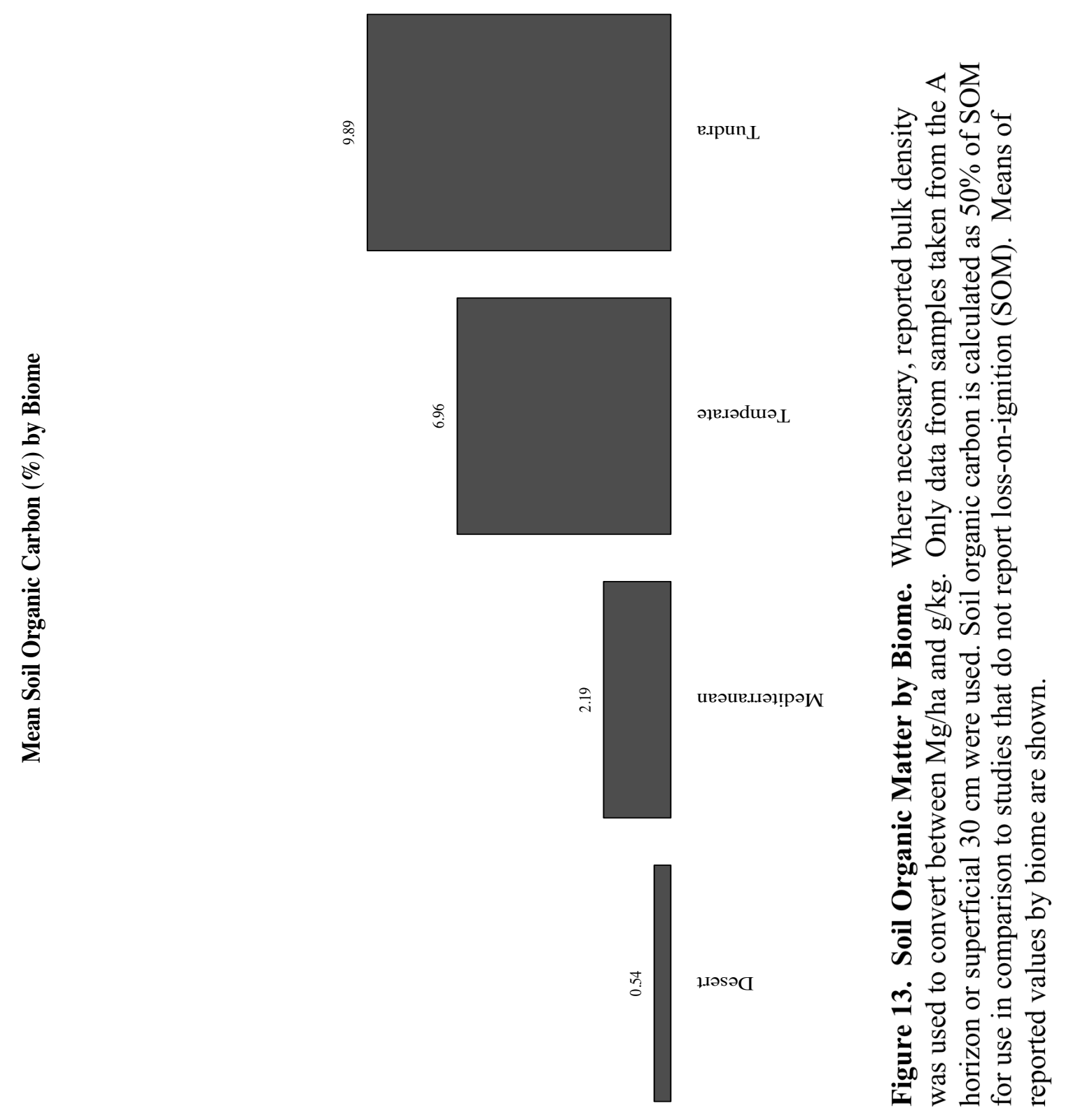




\section{References}

Adams A, Harrison R, Sletten R, Strahm B, Turnblom E, Jensen C (2005) Nitrogen-

Fertilization Impacts on Carbon Sequestration and Flux in Managed Coastal

Douglas-Fir Stands of the Pacific Northwest Forest Ecology and Management, 220, 313-325.

Akbari H, Bell R, Brazel T et al. (2008) Urban Heat Island Basics. In: Reducing Urban Heat Islands: Compendium of Strategies US EPA,

Batjes NH (1996) Total Carbon and Nitrogen in the Soils of the World European Journal of Soil Science, 47, 151-164.

Beck T, Joergensen R, Kandeler E, Makeschin F, Nuss E, Oberholzer H, Scheu S (1997) An Inter-Laboratory Comparison of Ten Different Ways of Measuring Soil Microbial Biomass C Soil Biology and Biochemistry, 29, 1023-1032.

Biasi C, Meyer H, Rusalimova O et al. (2008) Initial Effects of Experimental Warming on Carbon Exchange Rates, Plant Growth and Microbial Dynamics of a LichenRich Dwarf Shrub Tundra in Siberia Plant Soil, 307, 191-205.

Blagodatskaya E, Yuyukina T, Blagodatsky S, Kuzyakov Y (2011) Three-SourcePartitioning of Microbial Biomass and of Co2 Efflux From Soil to Evaluate Mechanisms of Priming Effects Soil Biology and Biochemistry, 43, 778-786.

Brady NC, Weil RR. The Nature and Properties of Soils (Pearson Education, Inc., Upper Saddle River, 2008).

Carreiro MM, Sinsabaugh R, Repert D, Parkhurst D (2000) Microbial Enzyme Shifts Explain Litter Decay Responses to Simulated Nitrogen Deposition Ecology, 81, 2359-2365. 
Carreiro MM, Tripler CE (2005) Forest Remnants Along Urban-Rural Gradients:

Examining Their Potential for Global Change Research Ecosystems, 8, 568-582.

Cebrian J, Duarte C (1995) Plant Growth-Rate Dependence of Detrital Carbon Storage in Ecosystems Science, 268, 1606-1608.

Chaer G, Myrold D, Bottomley P (2009) A Soil Quality Index Based on the Equilibrium

Between Soil Organic Matter and Biochemical Properties of Undisturbed

Coniferous Forest Soils of the Pacific Northwest Soil Biology and Biochemistry, 41, $822-830$.

Chen H, Tian H (2005) Does a General Temperature-Dependent Q10 Model of Soil Respiration Exist At Biome and Global Scale? Journal of Integrative Plant Biology, 47, 1288-1302.

City Of Portland Bureau of Planning and Sustainability (2010) Annexations to the City of Portland.

City Of Portland Bureau of Planning and Sustainability (2011) Zoning Designations. Conant RT, Drijber RA, Haddix ML, Parton WJ, Paul EA, Plante AF, Six J, Steinweg JM (2008) Sensitivity of Organic Matter Decomposition to Warming Varies With Its Quality Global Change Biology, 14, 868-877.

Cornwell W, Cornelissen J, Amatangelo K et al. (2008) Plant Species Traits Are the Predominant Control on Litter Decomposition Rates Within Biomes Worldwide. Ecol Lett, 11, 1065-1071.

Crow SE, Lajtha K, Bowden RD, Yano Y, Brant JB, Caldwell BA, Sulzman EW (2009a) Increased Coniferous Needle Inputs Accelerate Decomposition of Soil Carbon in an Old-Growth Forest Forest Ecology and Management, 258, 2224-2232. 
Crow SE, Lajtha K, Filley TR, Swanston CW, Bowden RD, Caldwell BA (2009b)

Sources of Plant-Derived Carbon and Stability of Organic Matter in Soil:

Implications for Global Change Global Change Biology, 15, 2003-2019.

Davidson EA, Trumbore SE, Amundson R (2000) Biogeochemistry: Soil Warming and Organic Carbon Content Nature, 408, 789-790.

Davidson E, Janssens I (2006) Temperature Sensitivity of Soil Carbon Decomposition and Feedbacks to Climate Change. Nature, 440, 165-173.

Eskelinen A, Stark S, Mannisto M (2009) Links Between Plant Community Composition, Soil Organic Matter Quality and Microbial Communities in Contrasting Tundra Habitats. Oecologia, 161, 113-123.

Fang C, Smith P, Moncrleff J, Smith J (2005) Similar Response of Labile and Resistant Soil Organic Matter Pools to Changes in Temperature Nature, 433(7021), 57-59.

Feng X, Simpson A, Wilson K, Williams D, Simpson M (2008) Increased Cuticular Carbon Sequestration and Lignin Oxidation in Response to Soil Warming Nature Geoscience, 1, 836-839.

George K, Ziska LH, Bunce JA, Quebedeaux B (2007) Elevated Atmospheric Co2 Concentration and Temperature Across an Urban?Rural Transect Atmospheric Environment, 41, 7654-7665.

Giardina CP, Ryan MG (2000) Evidence That Decomposition Rates of Organic Carbon in Mineral Soil Do Not Vary With Temperature Nature, 404, 858-861.

Gill S, Handley J, Ennos A, Pauleit S (2007) Adapting Cities for Climate Change: The Role of the Green Infrastructure Built Environment, 33. 
Golubiewski N (2006) Urbanization Increases Grassland Carbon Pools: Effects of Landscaping in Colorado's Front Range. Ecol Appl, 16, 555-571.

Green D, Oleksyszyn M (2002) Enzyme Activities and Carbon Dioxide Flux in a Sonoran Desert Urban Ecosystem Soil Science Society of America Journal, 66, 2002-2008

Griffiths RP, Bradshaw GA, Marks B, Lienkaemper GW (1996) Spatial Distribution of Ectomycorrhizal Mats in Coniferous Forests of the Pacific Northwest, USA Plant and soil, 180, 147-158.

Griffiths R, Madritch M, Swanson A (2009) The Effects of Topography on Forest Soil Characteristics in the Oregon Cascade Mountains (USA): Implications for the Effects of Climate Change on Soil Properties Forest Ecology and Management.

Grimm N, Faeth S, Golubiewski N, Redman C, Wu J, Bai X, Briggs J (2008) Global Change and the Ecology of Cities. Science, 319, 756-760.

Guenet B, Danger M, Abbadie L, Lacroix G (2010) Priming Effect: Bridging the Gap Between Terrestrial and Aquatic Ecology Ecology, 91, 2850-2861.

Hall J, Gillespie TW, Richardson D, Reader S (2002) Fragmentation of Florida Scrub in an Urban Landscape Urban Ecosystems, 6, 243-255.

Hartley IP, Ineson P (2008) Substrate Quality and the Temperature Sensitivity of Soil Organic Matter Decomposition Soil Biology and Biochemistry, 40, 1567-1574.

Heimann M, Reichstein M (2008) Terrestrial Ecosystem Carbon Dynamics and Climate Feedbacks. Nature, 451, 289-292. 
Homann P, Kapchinske J, Boyce A (2007) Relations of Mineral-Soil C and N to Climate and Texture: Regional Differences Within the Conterminous USA Biogeochemistry, 85, 303-316.

Homann P, Remillard S, Harmon M, Bormann B (2004) Carbon Storage in Coarse and Fine Fractions of Pacific Northwest Old-Growth Forest Soils Soil Science Society of America Journal, 68, 2023-2030.

Jenerette GD, Wu J, Grimm NB, Hope D (2006) Points, Patches, and Regions: Scaling Soil Biogeochemical Patterns in an Urbanized Arid Ecosystem Global Change Biol, 12, $1532-1544$.

Jenny H (1946) Arrangement of Soil Series and Types According to Functions of SoilForming Factors Soil Science, 61, 375.

Jo H (2002) Impacts of Urban Greenspace on Offsetting Carbon Emissions for Middle Korea Journal of Environmental Management, 64, 115-126.

Johnson K, Scatena F, Johnson A, Pan Y (2009) Controls on Soil Organic Matter Content Within a Northern Hardwood Forest Geoderma, 148, 346-356.

Jones CD, Cox P, Huntingford C (2003) Uncertainty in Climate-Carbon-Cycle Projections Associated With the Sensitivity of Soil Respiration to Temperature Tellus B, 55, 642-648.

King J, Thomas R, Strain B (1996) Growth and Carbon Accumulation in Root Systems of Pinus Taeda and Pinus Ponderosa Seedlings as Affected By Varying Co2, Temperature and Nitrogen Tree Physiology, 16, 635.

Kirschbaum M (2000) Will Changes in Soil Organic Carbon Act as a Positive Or Negative Feedback on Global Warming? Biogeochemistry, 48. 
Kleinbaum D, Kupper L, Muller K, Nizam A. Applied Regresion Analysis and Other Multivariate Methods (Brooks/Cole Publishing Company, Pacific Grove, CA, 1998). Klopatek JM (2002) Belowground Carbon Pools and Processes in Different Age Stands of Douglas-Fir Tree Physiology, 22, 197.

Kluber LA, Tinnesand KM, Caldwell BA, Dunham SM, Yarwood RR, Bottomley PJ, Myrold DD (2010) Ectomycorrhizal Mats Alter Forest Soil Biogeochemistry Soil Biology and Biochemistry, 42, 1607-1613.

Kong X, Dao TH, Qin J, Qin H, Li C, Zhang F (2009) Effects of Soil Texture and Land Use Interactions on Organic Carbon in Soils in North China Cities' Urban Fringe Geoderma, 154, 86-92.

Laudon H, Berggren M, Ågren A, Buffam I, Bishop K, Grabs T, Jansson M, Köhler S (2011) Patterns and Dynamics of Dissolved Organic Carbon (Doc) in Boreal Streams: The Role of Processes, Connectivity, and Scaling Ecosystems, 14, 880-893.

Leavitt S, Pendall E, Paul E, Brooks T, Kimball. B (2001) Stable-Carbon Isotopes and Soil Organic Carbon in the 1996 and 1997 Face Wheat Experiments New Phytologist.

Lehmann A, Stahr K (2007) Nature and Significance of Anthropogenic Urban Soils Journal of Soils and Sediments, 7, 247-260.

Lenton TM, Huntingford C (2003) Global Terrestrial Carbon Storage and Uncertainties in Its Temperature Sensitivity Examined With a Simple Model Global Change Biology, 9, 1333-1352.

Lorenz K, Lal R (2009) Biogeochemical C and N Cycles in Urban Soils. Environment International, 35(1), 1-8. 
Lu Y, Zhuang Q, Zhou G, Sirin A, Melillo J, Kicklighter D (2009) Possible Decline of the Carbon Sink in the Mongolian Plateau During the 21st Century Environ. Res. Lett., 4, 045023.

Lumley T (2009) Package 'Leaps'.

Luo Y, Su B, Currie W et al. (2004) Progressive Nitrogen Limitation of Ecosystem Response to Rising Atmospheric Carbon Dioxide Bioscience, 54, 733.

Marschner J. Oregon 1859: a snapshot in time (Timber Press, Portland, 2008).

Mcgarigal K, Cushman SA (2002) Comparative Evaluation of Experimental Approaches to the Study of Habitat Fragmentation Effects Ecological applications, 12, 335-345.

National Cooperative Soil Survey (2001) Official Series Description Multnomah Series.

Norby RJ, Delucia EH, Gielen B et al. (2005) Forest Response to Elevated Co2 is Conserved Across a Broad Range of Productivity Proceedings of the National Academy of Sciences of the United States of America, 102, 18052.

Nourbakhsh F (2007) Decoupling of Soil Biological Properties By Deforestation Agriculture, Ecosystems \& Environment, 121, 435-438.

Parsons AN, Barrett J, Wall DH, Virginia RA (2004) Soil Carbon Dioxide Flux in Antarctic Dry Valley Ecosystems Ecosystems, 7, 286-295.

Parton W, Schimel DS, Cole C, Ojima D (1987) Analysis of Factors Controlling Soil Organic Matter Levels in Great Plains Grasslands Soil Science Society of America journal (USA).

Paustian K, Parton WJ, Persson J (1992) Modeling Soil Organic Matter in OrganicAmended and Nitrogen-Fertilized Long-Term Plots Soil Science Society of America Journal, 56. 
Pavao-Zuckerman MA, Coleman D (2005) Decomposition of Chestnut Oak (Quercus

Prinus) Leaves and Nitrogen Mineralization in an Urban Environment Biology and

Fertility of Soils, 41, 343-349.

Pendall E, Bridgham S, Hanson PJ et al. (2004) Below-Ground Process Responses to Elevated Co2 and Temperature: A Discussion of Observations, Measurement

Methods, and Models New Phytologist, 162(2), 311-322.

Pickett S, Cadenasso M (2009) Altered Resources, Disturbance, and Heterogeneity: A

Framework for Comparing Urban and Non-Urban Soils Urban Ecosystems, 12, 2344.

Portland State University Population Research Center. 2010 Census Profiles Oregon Cities Alphabetically M-P (Portland State University, Portland, 2011).

Pouyat R, Yesilonis I, Golubiewski N (2009) A Comparison of Soil Organic Carbon Stocks Between Residential Turf Grass and Native Soil Urban Ecosystems, 12, 4562.

Pregitzer K, Zak D, Maziasz J, Deforest J, Curtis P, Lussenhop J (2000) Interactive Effects of Atmospheric Co2 and Soil-N Availability on Fine Roots of Populus Tremuloides Ecological Applications, 10, 18-33.

Pribyl DW (2010) A Critical Review of the Conventional Soc to Som Conversion Factor Geoderma, 156, 75-83.

Qian Y, Follett R, Kimble J (2010) Soil Organic Carbon Input From Urban Turfgrasses Soil Science Society of America Journal, 74, 366.

R Development Core Team (2011) R: A Language and Environment for Statistical Computing. 
Raich JW, Russell AE, Kitayama K, Parton WJ, Vitousek PM (2006) Temperature

Influences Carbon Accumulation in Moist Tropical Forests Ecology, 87, 76-87.

Reich P, Hobbie S, Lee T et al. (2006) Nitrogen Limitation Constrains Sustainability of

Ecosystem Response to Co2. Nature, 440, 922-925.

Ren Y, Wei X, Wei X, Pan J, Xie P, Song X, Peng D, Zhao J (2011) Relationship

Between Vegetation Carbon Storage and Urbanization: A Case Study of Xiamen, China Forest Ecology and Management, 261, 1214-1223.

Rezácová V, Hrselova H, Gryndlerova H, Miksík I, Gryndler M (2006) Modifications of

Degradation-Resistant Soil Organic Matter By Soil Saprobic Microfungi Soil

Biology and Biochemistry, 38, 2292-2299.

Rice A, Bostrom G (2011) Measurements of Carbon Dioxide in an Oregon Metropolitan Region Atmospheric Environment, 45, 1138-1144.

Scharenbroch B, Lloyed, Je, Johnson-Maynard, JL (2005) Distinguishing Urban Soils

With Physical, Chemical and Biological Properties Pedobiologia, 49, 283-296.

Schoonmaker P, Mckee A (1988) Species Composition and Diversity During Secondary

Succession of Coniferous Forests in the Western Cascade Mountains of Oregon

Forest Science, 34, 960-979.

Selmants P, Hart S, Boyle S, Stark J (2005) Red Alder (Alnus Rubra) Alters Community-

Level Soil Microbial Function in Conifer Forests of the Pacific Northwest, USA

Soil Biology and Biochemistry, 37, 1860-1868.

Shandas V (2008) Portland Blocks Percent Canopy Cover.

Shimadzu Corporation (2001) Total Organic Carbon Analyzer Toc-V Csh/Csn User

Manual. 
Smith JG (2003) Aspects of the Loss-On-Ignition (Loi) Technique in the Context of Clay-Rich, Glaciolacustrine Sediments Geografiska Annaler: Series A, Physical Geography, 85, 91-97.

Sollins P, Homann P, Caldwell BA (1996) Stabilization and Destabilization of Soil Organic Matter: Mechanisms and Controls Geoderma, 74.

Soussana J, Casella E, Loiseau P (1996) Long-Term Effects of Co 2 Enrichment and Temperature Increase on a Temperate Grass Sward Plant and Soil, 182, 101-114. Statistics Canada (2007) Vancouver, British Columbia 2006 Census, Statistics Canada Catalogue no. 92-591-XWE, 2006 Community Profiles.

Steinbeiss S, Beßler H, Engels C et al. (2008) Plant Diversity Positively Affects ShortTerm Soil Carbon Storage in Experimental Grasslands Global Change Biology, 14, 2937-2949.

Sun O, Campbell J, Law B, Wolf V (2004) Dynamics of Carbon Stocks in Soils and Detritus Across Chronosequences of Different Forest Types in the Pacific Northwest, USA Global Change Biology, 10, 1470-1481.

Sun Y, Ma J, Li C (2010) Content and Densities of Soil Organic Carbon in Urban Soil in Different Function Districts of Kaifeng Journal of Geographical Sciences, 20, 148156.

Swift MJ, Heal OW, Anderson JM. Decomposition in terrestrial ecosystems (University of California Press, 1979).

Thermo Scientific (2009) Organic Elemental Analysis Eager Xperience for Flash Elemental Analyzers Software Manual. 
Thermo Scientific Flash EA1112 Elemental Analyzer Operating Manual (Thermo

Electron Technical Publications, Milan, 2005).

United States Census Bureau (2010) Profile of General Populaion and Housing

Characteristics: 2010 (Detailed Table Dp-1) 2010 Demographic Profile Data.

United States Department of Commerce National Oceanic \& Atmospheric

Administration (2011) Portland International Airport Temperature and Precipitation

Normals 1981-2010.

United States Department Of Agriculture Natural Resources Conservation Service (1983)

Soil Survey of Multnomah County, Oregon.

Vauramo S, Setälä H (2011) Decomposition of Labile and Recalcitrant Litter Types

Under Different Plant Communities in Urban Soils Urban Ecosystems, 14, 59-70.

Von L, Margit, Kögel-Knabner I, Ludwig B et al. (2008) Stabilization Mechanisms of

Organic Matter in Four Temperate Soils: Development and Application of a

Conceptual Model J. Plant Nutr. Soil Sci., 171(1), 111-124.

Waldrop MP, Wickland KP, White I, R., Berhe AA, Harden JW, Romanovsky VE (2010)

Molecular Investigations Into a Globally Important Carbon Pool: Permafrost-

Protected Carbon in Alaskan Soils Global Change Biology.

Waldrop MP, Zak DR (2006) Response of Oxidative Enzyme Activities to Nitrogen

Deposition Affects Soil Concentrations of Dissolved Organic Carbon Ecosystems, 9, 921-933.

Wan S, Norby RJ, Pregitzer KS, Ledford J, O'Neill EG (2004) Co2 Enrichment and Warming of the Atmosphere Enhance Both Productivity and Mortality of Maple Tree Fine Roots New Phytologist, 162, 437-446. 
Wang M, Markert B, Shen W, Chen W, Peng C, Ouyang Z (2011) Microbial Biomass Carbon and Enzyme Activities of Urban Soils in Beijing. Environ Sci Pollut Res Int, 18, 958-967.

Yakovlev AS, Plekhanova IO, Kudryashov SV, Aimaletdinov RA (2008) Assessment and Regulation of the Ecological State of Soils in the Impact Zone of Mining and Metallurgical Enterprises of Norilsk Nickel Company Eurasian Soil Sc., 41, 648659.

Yang Y, Campbell C, Clark L, Cameron C, Paterson E (2006) Microbial Indicators of Heavy Metal Contamination in Urban and Rural Soils. Chemosphere, 63, 19421952.

Zak DR, Pregitzer KS, Curtis PS, Teeri JA, Fogel R, Randlett DL (1993) Elevated Atmospheric Co 2 and Feedback Between Carbon and Nitrogen Cycles Plant and Soil, 151, 105-117.

Zak DR, Pregitzer KS, King JS, Holmes WE (2000) Elevated Atmospheric Co2, Fine Roots and the Response of Soil Microorganisms: A Review and Hypothesis New Phytologist, 147(1), 201-222. 
Appendix A. Genera Recorded at Each Site. Unknown stems are numbered per site ID.

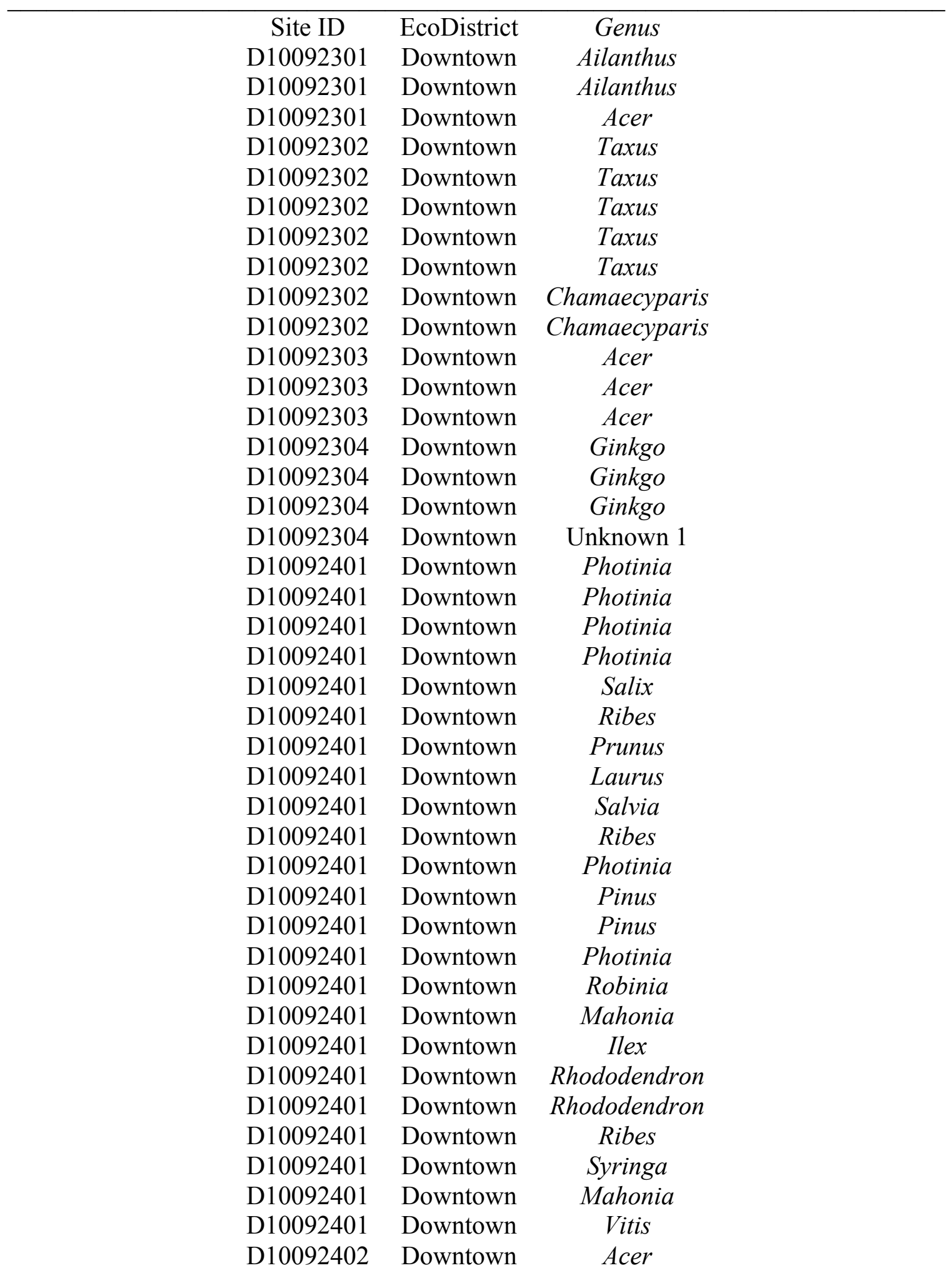




\begin{tabular}{|c|c|c|}
\hline D10092402 & Downtown & Sorbus \\
\hline D10092402 & Downtown & Acer \\
\hline D10092403 & Downtown & Rosa \\
\hline D10092403 & Downtown & Rosa \\
\hline D10092403 & Downtown & Styrax \\
\hline D10092403 & Downtown & Rosa \\
\hline D10092403 & Downtown & Rosa \\
\hline D10092403 & Downtown & Quercus \\
\hline D10092403 & Downtown & Quercus \\
\hline D10092403 & Downtown & Taxus \\
\hline D10092404 & Downtown & Acer \\
\hline D10092404 & Downtown & Acer \\
\hline D10092404 & Downtown & Acer \\
\hline D10092404 & Downtown & Acer \\
\hline D10092404 & Downtown & Tilia \\
\hline D10093001 & Downtown & Acer \\
\hline D10093001 & Downtown & Cotinus \\
\hline D10093001 & Downtown & Nandina \\
\hline D10093001 & Downtown & Nandina \\
\hline D10093001 & Downtown & Taxus \\
\hline D10093001 & Downtown & Taxus \\
\hline D10093001 & Downtown & Taxus \\
\hline D10093001 & Downtown & Viburnum \\
\hline D10093001 & Downtown & Viburnum \\
\hline D10093001 & Downtown & Panicum \\
\hline D10093001 & Downtown & Panicum \\
\hline D10093001 & Downtown & Eupatorium \\
\hline D10093001 & Downtown & Acer \\
\hline D10093001 & Downtown & Perovskia \\
\hline D10093001 & Downtown & Acer \\
\hline D10093001 & Downtown & Thuja \\
\hline D10093001 & Downtown & Taxus \\
\hline D10093001 & Downtown & Nandina \\
\hline D10100101 & Downtown & Ulmus \\
\hline D10100101 & Downtown & Ulmus \\
\hline D10100101 & Downtown & Ulmus \\
\hline D10100101 & Downtown & Tilia \\
\hline D10100101 & Downtown & Tilia \\
\hline D10100101 & Downtown & Tilia \\
\hline D10100101 & Downtown & Zelkova \\
\hline D10100101 & Downtown & Ulmus \\
\hline D10100101 & Downtown & Ulmus \\
\hline D10100102 & Downtown & Unknown 5 \\
\hline D10100102 & Downtown & Unknown 5 \\
\hline D10100102 & Downtown & Unknown 5 \\
\hline
\end{tabular}




$\begin{array}{ccc}\text { D10100102 } & \text { Downtown } & \text { Unknown 5 } \\ \text { D10100102 } & \text { Downtown } & \text { Unknown 5 } \\ \text { D10100102 } & \text { Downtown } & \text { Ulmus } \\ \text { D10100102 } & \text { Downtown } & \text { Prunus } \\ \text { D10100102 } & \text { Downtown } & \text { Ilex } \\ \text { D10100102 } & \text { Downtown } & \text { Pinus } \\ \text { D10100102 } & \text { Downtown } & \text { Unknown 3 } \\ \text { D10100102 } & \text { Downtown } & \text { Populus } \\ \text { D10100102 } & \text { Downtown } & \text { Populus } \\ \text { D10100102 } & \text { Downtown } & \text { Populus } \\ \text { D10100102 } & \text { Downtown } & \text { Populus } \\ \text { D10100102 } & \text { Downtown } & \text { Populus } \\ \text { D10100102 } & \text { Downtown } & \text { Populus } \\ \text { D10100102 } & \text { Downtown } & \text { Populus } \\ \text { D10100102 } & \text { Downtown } & \text { Populus } \\ \text { D10100102 } & \text { Downtown } & \text { Unknown 4 } \\ \text { D10100102 } & \text { Downtown } & \text { Unknown 5 } \\ \text { D10100102 } & \text { Downtown } & \text { Unknown 5 } \\ \text { D10100102 } & \text { Downtown } & \text { Abelia } \\ \text { D10100102 } & \text { Downtown } & \text { Mahonia } \\ \text { D10100102 } & \text { Downtown } & \text { Viburnum } \\ \text { D10100102 } & \text { Downtown } & \text { Abelia } \\ \text { D10100102 } & \text { Downtown } & \text { Abelia } \\ \text { D10100102 } & \text { Downtown } & \text { Rhododendron } \\ \text { D10100102 } & \text { Downtown } & \text { Abelia } \\ \text { D10100102 } & \text { Downtown } & \text { Rhododendron } \\ \text { D10100102 } & \text { Downtown } & \text { Rhododendron } \\ \text { D10100102 } & \text { Downtown } & \text { Rhododendron } \\ \text { D10100102 } & \text { Downtown } & \text { Rhododendron } \\ \text { D10100102 } & \text { Downtown } & \text { Abelia } \\ \text { D10100102 } & \text { Downtown } & \text { Rhododendron } \\ \text { D10100201 } & \text { Downtown } & \text { Euonymous } \\ \text { D10100102 } & \text { Downtown } & \text { Ilex } \\ \text { D10100102 } & \text { Downtown } & \text { NA } \\ \text { D10100102 } & \text { Downtown } & \text { Rhododendron } \\ \text { D10100102 } & \text { Downtown } & \text { Rhododendron } \\ \text { D10100102 } & \text { Downtown } & \text { Rhododendron } \\ \text { D10100102 } & \text { Downtown } & \text { Rhododendron } \\ \text { D10100102 } & \text { Downtown } & \text { Magnolia } \\ \text { D10100102 } & \text { Downtown } & \text { Magnolia } \\ \text { D10100102 } & \text { Downtown } & \text { Rhododendron } \\ \text { Downtown } & \text { Rhododendron } \\ \text { Acer } \\ \text { Acer }\end{array}$




$\begin{array}{lcc}\text { D10100201 } & \text { Downtown } & \text { Euonymous } \\ \text { D10100201 } & \text { Downtown } & \text { Euonymous } \\ \text { D10100201 } & \text { Downtown } & \text { Acer } \\ \text { D10100201 } & \text { Downtown } & \text { Acer } \\ \text { D10100201 } & \text { Downtown } & \text { Acer } \\ \text { D10100202 } & \text { Downtown } & \text { Buxus } \\ \text { D10100202 } & \text { Downtown } & \text { Rhododendron } \\ \text { D10100202 } & \text { Downtown } & \text { Rhododendron } \\ \text { D10100202 } & \text { Downtown } & \text { Pieris } \\ \text { D10100202 } & \text { Downtown } & \text { Pieris } \\ \text { D10100202 } & \text { Downtown } & \text { Juniperus } \\ \text { D10100202 } & \text { Downtown } & \text { Buxus } \\ \text { D10100202 } & \text { Downtown } & \text { Cornus } \\ \text { D10100202 } & \text { Downtown } & \text { Acer } \\ \text { D10100202 } & \text { Downtown } & \text { Acer } \\ \text { D10100202 } & \text { Downtown } & \text { Acer } \\ \text { D10100203 } & \text { Downtown } & \text { Acer } \\ \text { D10100203 } & \text { Downtown } & \text { Acer } \\ \text { D10100203 } & \text { Downtown } & \text { Acer } \\ \text { D10100203 } & \text { Downtown } & \text { Acer } \\ \text { D10100203 } & \text { Downtown } & \text { Acer } \\ \text { D10100203 } & \text { Downtown } & \text { Acer } \\ \text { D10100204 } & \text { Downtown } & \text { Rhododendron } \\ \text { D10100204 } & \text { Downtown } & \text { Rhododendron } \\ \text { D10100204 } & \text { Downtown } & \text { Berberis } \\ \text { D10100204 } & \text { Downtown } & \text { Camellia } \\ \text { D10100204 } & \text { Downtown } & \text { Arbutus } \\ \text { D10100204 } & \text { Downtown } & \text { Arbutus } \\ \text { D10100204 } & \text { Downtown } & \text { Pinus } \\ \text { D10100204 } & \text { Downtown } & \text { Rhododendron } \\ \text { D10100204 } & \text { Downtown } & \text { Gaultheria } \\ \text { D10100204 } & \text { Downtown } & \text { Pinus } \\ \text { D10100204 } & \text { Downtown } & \text { Ulmus } \\ \text { D10100204 } & \text { Downtown } & \text { Ulmus } \\ \text { D10100204 } & \text { Downtown } & \text { Ulmus } \\ \text { D10100801 } & \text { Downtown } & \text { Camellia } \\ \text { D10100801 } & \text { Downtown } & \text { Buxus } \\ \text { D10100801 } & \text { Downtown } & \text { Buxus } \\ \text { D10100801 } & \text { Downtown } & \text { Nandina } \\ \text { D10100801 } & \text { Downtown } & \text { Buxus } \\ \text { D10100801 } & \text { Downtown } & \text { Buxus } \\ \text { D10100801 } & \text { Downtown } & \text { Nandina } \\ \text { Downtown } & \text { Downtown } & \text { Rhododendron } \\ \text { Dious }\end{array}$




\begin{tabular}{|c|c|c|}
\hline D10100802 & Downtown & Zelkova \\
\hline D10100802 & Downtown & Acer \\
\hline D10100802 & Downtown & Zelkova \\
\hline D10100802 & Downtown & Zelkova \\
\hline D10100803 & Downtown & Zelkova \\
\hline D10100803 & Downtown & Zelkova \\
\hline D10100803 & Downtown & Zelkova \\
\hline D10100803 & Downtown & Acer \\
\hline D10100804 & Downtown & Arbutus \\
\hline D10100804 & Downtown & Arbutus \\
\hline D10100804 & Downtown & Arbutus \\
\hline D10100804 & Downtown & Betula \\
\hline D10100804 & Downtown & Liriodendron \\
\hline D10100804 & Downtown & Liriodendron \\
\hline D10100804 & Downtown & Acer \\
\hline D10100804 & Downtown & Acer \\
\hline D10100804 & Downtown & Acer \\
\hline D10100804 & Downtown & Photinia \\
\hline D10100804 & Downtown & Ilex \\
\hline D10100804 & Downtown & Thuja \\
\hline D10100804 & Downtown & Thuja \\
\hline D10100804 & Downtown & Thuja \\
\hline D10100804 & Downtown & Thuja \\
\hline D10100804 & Downtown & Thuja \\
\hline D10100804 & Downtown & Ilex \\
\hline D10100804 & Downtown & Ilex \\
\hline D10100804 & Downtown & Spirea \\
\hline D10100804 & Downtown & Spirea \\
\hline D10100804 & Downtown & Spirea \\
\hline D10100805 & Downtown & Tilia \\
\hline D10100805 & Downtown & Tilia \\
\hline D10100805 & Downtown & Tilia \\
\hline D10100805 & Downtown & Tilia \\
\hline D10100805 & Downtown & Tilia \\
\hline D10100805 & Downtown & Acer \\
\hline D10100805 & Downtown & Photinia \\
\hline D10100805 & Downtown & Thuja \\
\hline D10100805 & Downtown & Photinia \\
\hline D10100805 & Downtown & Thuja \\
\hline D10100805 & Downtown & Photinia \\
\hline D10100901 & Downtown & Acer \\
\hline D10100901 & Downtown & Ulmus \\
\hline D10100901 & Downtown & Ulmus \\
\hline D10100901 & Downtown & Ulmus \\
\hline D10100901 & Downtown & Ulmus \\
\hline
\end{tabular}




\begin{tabular}{|c|c|c|}
\hline D10100901 & Downtown & Acer \\
\hline D10100901 & Downtown & Acer \\
\hline D10100901 & Downtown & Acer \\
\hline D10100901 & Downtown & Acer \\
\hline D10100902 & Downtown & Acer \\
\hline D10100902 & Downtown & Ulmus \\
\hline D10100902 & Downtown & Ulmus \\
\hline D10100902 & Downtown & Ulmus \\
\hline D10100902 & Downtown & Leucothoe \\
\hline D10100902 & Downtown & Ulmus \\
\hline D10100902 & Downtown & Acer \\
\hline D10100902 & Downtown & Acer \\
\hline D10100902 & Downtown & Acer \\
\hline D10100902 & Downtown & Leucothoe \\
\hline D10100902 & Downtown & Leucothoe \\
\hline D10100902 & Downtown & Leucothoe \\
\hline D10100902 & Downtown & Rhododendron \\
\hline D10100902 & Downtown & Leucothoe \\
\hline D10100902 & Downtown & Leucothoe \\
\hline D10100902 & Downtown & Leucothoe \\
\hline D10100902 & Downtown & Leucothoe \\
\hline D10100903 & Downtown & Acer \\
\hline D10100903 & Dor & Acer \\
\hline D10100903 & Downtown & Acer \\
\hline 0903 & Downtown & Viburnum \\
\hline D10100903 & Downtown & Viburnum \\
\hline D10100903 & Downtown & Viburnum \\
\hline D10100903 & Downtown & Viburnum \\
\hline D10100903 & Downtown & Acer \\
\hline D10100903 & Downtown & Viburnum \\
\hline D10100903 & own & Viburnum \\
\hline D10100904 & Downtown & Cupressus \\
\hline D10100904 & Downtown & Juniperus \\
\hline D10100904 & Downtown & Photinia \\
\hline D10100904 & Downtown & Acer \\
\hline D10100904 & Downtown & Acer \\
\hline D10100904 & Downtown & Acer \\
\hline D10100904 & Downtown & Arctostaphylos \\
\hline D10100904 & Downtown & Acer \\
\hline D10100904 & Downtown & Acer \\
\hline D10100904 & Downtown & Acer \\
\hline D10100904 & Downtown & Arctostaphylo \\
\hline D10100905 & Downtown & Betula \\
\hline D10100905 & Downtown & Betula \\
\hline D10100905 & Downtown & Zelkova \\
\hline
\end{tabular}




$\begin{array}{lcc}\text { D10100905 } & \text { Downtown } & \text { Zelkova } \\ \text { D10101401 } & \text { Downtown } & \text { Ulmus } \\ \text { D10101401 } & \text { Downtown } & \text { Ulmus } \\ \text { D10101401 } & \text { Downtown } & \text { Ulmus } \\ \text { D10101401 } & \text { Downtown } & \text { Ulmus } \\ \text { D10101401 } & \text { Downtown } & \text { Ulmus } \\ \text { D10101401 } & \text { Downtown } & \text { Ulmus } \\ \text { D10101401 } & \text { Downtown } & \text { Ulmus } \\ \text { D10101401 } & \text { Downtown } & \text { Ulmus } \\ \text { D10101402 } & \text { Downtown } & \text { Acer } \\ \text { D10101402 } & \text { Downtown } & \text { Acer } \\ \text { D10101402 } & \text { Downtown } & \text { Acer } \\ \text { D10101402 } & \text { Downtown } & \text { Acer } \\ \text { D10101402 } & \text { Downtown } & \text { Acer } \\ \text { D10101403 } & \text { Downtown } & \text { Pinus } \\ \text { D10101403 } & \text { Downtown } & \text { Ulmus } \\ \text { D10101403 } & \text { Downtown } & \text { Pinus } \\ \text { D10101403 } & \text { Downtown } & \text { Ginkgo } \\ \text { D10101403 } & \text { Downtown } & \text { Mahonia } \\ \text { D10101403 } & \text { Downtown } & \text { Mahonia } \\ \text { D10101404 } & \text { Downtown } & \text { Platanus } \\ \text { D10101404 } & \text { Downtown } & \text { Platanus } \\ \text { D10101404 } & \text { Downtown } & \text { Platanus } \\ \text { D10101405 } & \text { Downtown } & \text { Liquidambar } \\ \text { D10101405 } & \text { Downtown } & \text { Liquidambar } \\ \text { D10101405 } & \text { Downtown } & \text { Liquidambar } \\ \text { D10101501 } & \text { Downtown } & \text { Ulmus } \\ \text { D10101501 } & \text { Downtown } & \text { Tilia } \\ \text { D10101501 } & \text { Downtown } & \text { Tilia } \\ \text { D10101501 } & \text { Downtown } & \text { Ulmus } \\ \text { D10101501 } & \text { Downtown } & \text { Rhododendron } \\ \text { D1010101501501 } & \text { Downtown } & \text { Rhododendron } \\ \text { D10101501 } & \text { Downtown } & \text { Rhododendron } \\ \text { D10101501 } & \text { Downtown } & \text { Rhododendron } \\ \text { D10101501 } & \text { Downtown } & \text { Rhododendron } \\ \text { D10101501 } & \text { Downtown } & \text { Acer } \\ \text { D10101501 } & \text { Downtown } & \text { Rhododendron } \\ \text { D10101501 } & \text { Downtown } & \text { Nandina } \\ \text { D10101501 } & \text { Downtown } & \text { Nandina } \\ \text { D10101501 } & \text { Downtown } & \text { Rhododendron } \\ \text { D101501 } & \text { Downtown } & \text { Rhododendron } \\ \text { Diontown } & \text { Rhododendron }\end{array}$




\begin{tabular}{|c|c|c|}
\hline D10101501 & Downtown & Nandina \\
\hline D10101501 & Downtown & Abelia \\
\hline D10101501 & Downtown & Pieris \\
\hline D10101502 & Downtown & Acer \\
\hline D10101503 & Downtown & Acer \\
\hline D10101503 & Downtown & Acer \\
\hline D10101503 & Downtown & Acer \\
\hline D10101503 & Downtown & Pyrus \\
\hline D10101503 & Downtown & Pyrus \\
\hline D10101503 & Downtown & Thuja \\
\hline D10101503 & Downtown & Pyrus \\
\hline D10101503 & Downtown & Photinia \\
\hline D10101503 & Downtown & Pyrus \\
\hline D10101503 & Downtown & Pyrus \\
\hline D10101503 & Downtown & Pyrus \\
\hline D10101503 & Downtown & Pyrus \\
\hline D10101503 & Downtown & Acer \\
\hline D10101504 & Downtown & Acer \\
\hline D10101504 & Downtown & Acer \\
\hline D10101504 & Downtown & Quercus \\
\hline D10101504 & Downtown & Acer \\
\hline D10101504 & Downtown & Quercus \\
\hline D10101504 & Downtown & Acer \\
\hline D10101504 & Downtown & Acer \\
\hline D10101504 & Downtown & Acer \\
\hline D10101504 & Downtown & Acer \\
\hline D10101504 & Downtown & Acer \\
\hline D10101504 & Downtown & Pinus \\
\hline D10101504 & Downtown & Pinus \\
\hline D10101504 & Downtown & Acer \\
\hline D10101504 & Downtown & Rhododendron \\
\hline D10101504 & Downtown & Rhododendron \\
\hline D10101504 & Downtown & Rhododendron \\
\hline D10101504 & Downtown & Mahonia \\
\hline D10101504 & Downtown & Rhododendron \\
\hline D10101504 & Downtown & Sarcococca \\
\hline D10101504 & Downtown & Sarcococca \\
\hline D10101504 & Downtown & Sarcococca \\
\hline D10101504 & Downtown & Ribes \\
\hline D10101504 & Downtown & Rhododendron \\
\hline D10101505 & Downtown & Acer \\
\hline D10101505 & Downtown & Acer \\
\hline D10101505 & Downtown & Acer \\
\hline D10101505 & Downtown & Acer \\
\hline D10101505 & Downtown & Acer \\
\hline
\end{tabular}




\begin{tabular}{|c|c|c|}
\hline 10101505 & Downtown & Quercus \\
\hline D10101505 & Downtown & Acer \\
\hline 10101505 & Downtown & Quercus \\
\hline D10101505 & Downtown & Pinus \\
\hline 10101505 & Downtown & Rhododendron \\
\hline 10101505 & Downtown & Pinus \\
\hline 10101505 & Downtown & Pinus \\
\hline D10101505 & Downtown & Rhododendron \\
\hline D10101505 & Downtown & Acer \\
\hline D10101505 & Downtown & Acer \\
\hline D10101505 & Downtown & Pinus \\
\hline D10101505 & Downtown & Pinus \\
\hline D10101505 & Downtown & Pinus \\
\hline D10101505 & Downtown & Pinus \\
\hline D10101505 & Downtown & Rhododendron \\
\hline D10101505 & Downtown & Mahonia \\
\hline D10101505 & Downtown & Rhododendron \\
\hline D10101505 & Downtown & Sarcococca \\
\hline D10101505 & Downtown & Sarcococca \\
\hline D10101505 & Downtown & Sarcococca \\
\hline D10101505 & Downtown & Ribes \\
\hline D10101505 & Downtown & Rhododendron \\
\hline D10101505 & Downtown & Pinus \\
\hline D10101505 & Downtown & Rhododendron \\
\hline D10101601 & Downtown & Rhododendron \\
\hline D10101601 & Downtown & Rhododendron \\
\hline D10101601 & Downtown & Rhododendron \\
\hline D10101601 & Downtown & Quercus \\
\hline D10101601 & Downtown & Quercus \\
\hline D10101601 & Downtown & Ulmus \\
\hline D10101601 & Downtown & Ulmus \\
\hline D10101601 & Downtown & Quercus \\
\hline D10101601 & Downtown & Acer \\
\hline D10101601 & Downtown & Rhododendron \\
\hline D10101601 & Downtown & Pieris \\
\hline D10101602 & Downtown & Quercus \\
\hline D10101602 & Downtown & Carpinus \\
\hline D10101602 & Downtown & Pinus \\
\hline D10101602 & Downtown & Prunus \\
\hline D10101602 & Downtown & Ulmus \\
\hline D10101603 & Downtown & Acer \\
\hline D10101603 & Downtown & Ilex \\
\hline D10101603 & Downtown & Ilex \\
\hline D10101603 & Downtown & Ilex \\
\hline D10101603 & Downtown & Ilex \\
\hline
\end{tabular}




\begin{tabular}{|c|c|c|}
\hline D10101603 & Downtown & Ilex \\
\hline D10101603 & Downtown & Ilex \\
\hline D10101603 & Downtown & Ilex \\
\hline D10101603 & Downtown & Ilex \\
\hline D10101603 & Downtown & Quercus \\
\hline D10101603 & Downtown & Ilex \\
\hline D10101603 & Downtown & Ilex \\
\hline D10101604 & Downtown & Acer \\
\hline D10101604 & Downtown & Rhododendron \\
\hline D10101604 & Downtown & Pinus \\
\hline D10101604 & Downtown & Thuja \\
\hline D10101604 & Downtown & Photinia \\
\hline D10101604 & Downtown & Quercus \\
\hline D10101604 & Downtown & Cornus \\
\hline D10101604 & Downtown & Cornus \\
\hline D10101604 & Downtown & Mahonia \\
\hline D10101604 & Downtown & Abies \\
\hline D10101604 & Downtown & Mahonia \\
\hline D10101604 & Downtown & Abies \\
\hline D10101604 & Downtown & Acer \\
\hline D10101604 & Downtown & Liquidambar \\
\hline D10101604 & Downtown & Mahonia \\
\hline D10101604 & Downtown & Gaylussacia \\
\hline D10101604 & Downtown & Gaylussacia \\
\hline D10101604 & Downtown & Gaylussacia \\
\hline D10102101 & Downtown & Koelreuteria \\
\hline D10102101 & Downtown & Cercis \\
\hline D10102101 & Downtown & Cercis \\
\hline D10102101 & Downtown & Gleditsia \\
\hline D10102101 & Downtown & Cercis \\
\hline D10102101 & Downtown & Cercis \\
\hline D10102101 & Downtown & Prunus \\
\hline D10102101 & Downtown & Prunus \\
\hline D10102101 & Downtown & Prunus \\
\hline D10102101 & Downtown & Prunus \\
\hline D10102101 & Downtown & Prunus \\
\hline D10102101 & Downtown & Gleditsia \\
\hline D10102101 & Downtown & Ilex \\
\hline D10102101 & Downtown & Buxus \\
\hline D10102101 & Downtown & Berberis \\
\hline D10102101 & Downtown & Berberis \\
\hline D10102101 & Downtown & Acer \\
\hline D10102101 & Downtown & Cotoneaster \\
\hline D10102101 & Downtown & Berberis \\
\hline D10102101 & Downtown & Cotoneaste \\
\hline
\end{tabular}




\begin{tabular}{|c|c|c|}
\hline D10102101 & Downtown & Cotoneaster \\
\hline D10102101 & Downtown & Viburnum \\
\hline D10102101 & Downtown & Berberis \\
\hline D10102101 & Downtown & Aronia \\
\hline D10102101 & Downtown & Ilex \\
\hline D10102101 & Downtown & Cotoneaster \\
\hline D10102101 & Downtown & Cotoneaster \\
\hline D10102101 & Downtown & Ilex \\
\hline D10102101 & Downtown & Berberis \\
\hline D10102101 & Downtown & Viburnum \\
\hline D10102101 & Downtown & Rosa \\
\hline D10102101 & Downtown & Buxus \\
\hline D10102101 & Downtown & Rosa \\
\hline D10102101 & Downtown & Rosa \\
\hline D10102101 & Downtown & Hydrangea \\
\hline D10102101 & Downtown & Berberis \\
\hline D10102101 & Downtown & Berberis \\
\hline D10102101 & Downtown & Viburnum \\
\hline D10102101 & Downtown & Unknown 1 \\
\hline D10102101 & Downtown & Unknown 1 \\
\hline D10102101 & Downtown & Unknown 1 \\
\hline D10102101 & Downtown & Unknown 1 \\
\hline D10102101 & Downtown & Unknown 1 \\
\hline D10102101 & Downtown & Unknown 1 \\
\hline D10102101 & Downtown & Daphne \\
\hline D10102101 & Downtown & Prunus \\
\hline D10102101 & Downtown & Malus \\
\hline D10102101 & Downtown & Viburnum \\
\hline D10102101 & Downtown & Cotoneaster \\
\hline D10102101 & Downtown & Unknown 1 \\
\hline & Downtown & Viburnum \\
\hline D10102101 & Downtown & Cotoneaster \\
\hline D10102101 & Downtown & Unknown 1 \\
\hline D10102101 & Downtown & Unknown 1 \\
\hline D10102101 & Downtown & Viburnum \\
\hline D10102102 & Downtown & Sorbus \\
\hline D10102102 & Downtown & Cotoneaster \\
\hline D10102102 & Downtown & Cotoneaster \\
\hline D10102102 & Downtown & Cotoneaster \\
\hline D10102102 & Downtown & Cotoneaster \\
\hline D10102102 & Downtown & Cotoneaster \\
\hline D10102102 & Downtown & Cotoneaster \\
\hline D10102102 & Downtown & Cotoneaster \\
\hline D10102102 & Downtown & Cotoneaster \\
\hline D10102102 & Downtown & Cotoneaster \\
\hline
\end{tabular}




\begin{tabular}{|c|c|c|}
\hline D10102102 & Downtown & Cotoneaster \\
\hline D10102102 & Downtown & Cotoneaster \\
\hline D10102102 & Downtown & Cotoneaster \\
\hline D10102102 & Downtown & Cotoneaster \\
\hline D10102102 & Downtown & Cotoneaster \\
\hline D10102102 & Downtown & Cotoneaster \\
\hline D10102102 & Downtown & Cotoneaster \\
\hline D10102102 & Downtown & Cotoneaster \\
\hline D10102102 & Downtown & Cotoneaster \\
\hline D10102102 & Downtown & Cotoneaster \\
\hline D10102102 & Downtown & Cotoneaster \\
\hline D10102102 & Downtown & Cotoneaster \\
\hline D10102102 & Downtown & Cotoneaster \\
\hline D10102102 & Downtown & Cotoneaster \\
\hline D10102102 & Downtown & Cotoneaster \\
\hline D10102102 & Downtown & Cotoneaster \\
\hline D10102201 & Downtown & Acer \\
\hline D10102201 & Downtown & Acer \\
\hline D10102202 & Downtown & Metasequoia \\
\hline D10102202 & Downtown & Dianthus \\
\hline D10102202 & Downtown & Acer \\
\hline D10102202 & Downtown & Metasequoia \\
\hline D10102202 & Downtown & Acer \\
\hline D10102202 & Downtown & Metasequo \\
\hline D10102202 & Downtown & Spirea \\
\hline D10102202 & Downtown & Spirea \\
\hline D10102202 & Downtown & Nandina \\
\hline D10102202 & Downtown & Nandina \\
\hline D10102203 & Downtown & Unknown 1 \\
\hline D10102203 & Downtown & Unknown 1 \\
\hline D10102203 & Downtown & Hamamelis \\
\hline D10102203 & Downtown & Quercus \\
\hline D10102203 & Downtown & Quercus \\
\hline D10102203 & Downtown & Quercus \\
\hline D10102203 & Downtown & Acer \\
\hline D10102203 & Downtown & Acer \\
\hline D10102203 & Downtown & Acer \\
\hline D10102203 & Downtown & Acer \\
\hline D10102203 & Downtown & Quercus \\
\hline D10102203 & Downtown & Viburnum \\
\hline D10102203 & Downtown & Unknown 2 \\
\hline D10102203 & Downtown & Unknown 2 \\
\hline D10102203 & Downtown & Unknown 2 \\
\hline D10102203 & Downtown & Berberis \\
\hline D10102203 & Downtown & Euonymous \\
\hline
\end{tabular}




\begin{tabular}{|c|c|c|}
\hline D10102203 & Downtown & Euonymous \\
\hline D10102203 & Downtown & Berberis \\
\hline D10102203 & Downtown & Berberis \\
\hline D10102203 & Downtown & Berberis \\
\hline D10102203 & Downtown & Berberis \\
\hline D10102203 & Downtown & Berberis \\
\hline D10102203 & Downtown & Berberis \\
\hline D10102203 & Downtown & Berberis \\
\hline D10102203 & Downtown & Berberis \\
\hline D10102203 & Downtown & Prunus \\
\hline D10102203 & Downtown & Prunus \\
\hline D10102203 & Downtown & Euonymous \\
\hline D10102203 & Downtown & Euonymous \\
\hline D10102203 & Downtown & Euonymous \\
\hline D10102203 & Downtown & Prunus \\
\hline D10102203 & Downtown & Berberis \\
\hline D10102203 & Downtown & Loropetalum \\
\hline D10102203 & Downtown & Euonymous \\
\hline D10102203 & Downtown & Euonymous \\
\hline D10102203 & Downtown & Euonymous \\
\hline D10102203 & Downtown & Euonymous \\
\hline D10102203 & Downtown & Euonymous \\
\hline D10102203 & Downtown & Loropetalum \\
\hline D10102203 & Downtown & Euonymous \\
\hline D10102203 & Downtown & Euonymous \\
\hline D10102203 & Downtown & Euonymous \\
\hline D10102204 & Downtown & Acer \\
\hline D10102204 & Downtown & Acer \\
\hline D10102204 & Downtown & Acer \\
\hline D10102204 & Downtown & Acer \\
\hline D10102204 & Downtown & Acer \\
\hline D10102204 & Downtown & Acer \\
\hline D10102204 & Downtown & Acer \\
\hline D10102204 & Downtown & Acer \\
\hline D10102204 & Downtown & Platanus \\
\hline D10102204 & Downtown & Photinia \\
\hline D10102204 & Downtown & Euonymous \\
\hline D10102204 & Downtown & Euonymous \\
\hline D10102204 & Downtown & Photinia \\
\hline D10102204 & Downtown & Photinia \\
\hline D10102204 & Downtown & Photinia \\
\hline D10102204 & Downtown & Photinia \\
\hline D10102204 & Downtown & Abelia \\
\hline D10102204 & Downtown & Abelia \\
\hline D10102204 & Downtown & Abelia \\
\hline
\end{tabular}




\begin{tabular}{|c|c|c|}
\hline D10102204 & Downtown & Abelia \\
\hline D10102204 & Downtown & Abelia \\
\hline D10102204 & Downtown & Photinia \\
\hline D10102204 & Downtown & Photinia \\
\hline D10102204 & Downtown & Photinia \\
\hline D10102204 & Downtown & Photinia \\
\hline D10102204 & Downtown & Photinia \\
\hline D10102204 & Downtown & Photinia \\
\hline D10102205 & Downtown & Malus \\
\hline D10102205 & Downtown & Malus \\
\hline D10102205 & Downtown & Malus \\
\hline D10102205 & Downtown & Malus \\
\hline D10102205 & Downtown & Malus \\
\hline D10102205 & Downtown & Malus \\
\hline D10102205 & Downtown & Malus \\
\hline D10102205 & Downtown & Malus \\
\hline D10102205 & Downtown & Malus \\
\hline D10102205 & Downtown & Leucothoe \\
\hline D10102205 & Downtown & Leucothoe \\
\hline D10102205 & Downtown & Leucothoe \\
\hline D10102205 & Downtown & Leucothoe \\
\hline D10102205 & Downtown & Euonymous \\
\hline D10102205 & Downtown & Euonymous \\
\hline D10102205 & Downtown & Leucothoe \\
\hline D10102205 & Downtown & Euonymous \\
\hline D10102205 & Downtown & Leucothoe \\
\hline D10102205 & Downtown & Leucothoe \\
\hline D10102206 & Downtown & Quercus \\
\hline D10102206 & Downtown & Quercus \\
\hline D10102206 & Downtown & Robinia \\
\hline D10102206 & Downtown & Robinia \\
\hline D10102206 & Downtown & Acer \\
\hline D10102207 & Downtown & Acer \\
\hline D10102207 & Downtown & Acer \\
\hline D10102207 & Downtown & Robinia \\
\hline D10102207 & Downtown & Robinia \\
\hline D10102207 & Downtown & Robinia \\
\hline D10102207 & Downtown & Robinia \\
\hline D10102207 & Downtown & Robinia \\
\hline D10102207 & Downtown & Robinia \\
\hline D10102207 & Downtown & Robinia \\
\hline D10102207 & Downtown & Robinia \\
\hline D10102207 & Downtown & Robinia \\
\hline D10102207 & Downtown & Calocedrus \\
\hline D10102207 & Downtown & Erica \\
\hline
\end{tabular}




\begin{tabular}{|c|c|c|}
\hline D10102207 & Downtown & Spirea \\
\hline D10102207 & Downtown & Spirea \\
\hline D10102207 & Downtown & Spirea \\
\hline D10102207 & Downtown & Mahonia \\
\hline D10102207 & Downtown & Calocedrus \\
\hline G10082601 & Gateway & Pseudotsuga \\
\hline G10082601 & Gateway & Pseudotsuga \\
\hline G10082601 & Gateway & Quercus \\
\hline G10082601 & Gateway & Pseudotsuga \\
\hline G10082601 & Gateway & Acer \\
\hline G10082601 & Gateway & Acer \\
\hline G10082601 & Gateway & Pseudotsuga \\
\hline G10082601 & Gateway & Quercus \\
\hline G10082601 & Gateway & Pseudotsuga \\
\hline G10082601 & Gateway & Pinus \\
\hline G10082601 & Gateway & Quercus \\
\hline G10082601 & Gateway & Acer \\
\hline G10082601 & Gateway & Acer \\
\hline G10082601 & Gateway & Acer \\
\hline G10082601 & Gateway & Acer \\
\hline G10082601 & Gateway & Acer \\
\hline G10082601 & Gateway & Acer \\
\hline G10082601 & Gateway & Acer \\
\hline G10082601 & Gateway & Acer \\
\hline G10082601 & Gateway & Acer \\
\hline G10082601 & Gateway & Cornus \\
\hline G10082601 & Gateway & Pseudotsuga \\
\hline G10082601 & Gateway & Pseudotsuga \\
\hline G10082601 & Gateway & Calocedrus \\
\hline G10082601 & Gateway & Pseudotsuga \\
\hline G10082601 & Gateway & Pseudotsuga \\
\hline G10082602 & Gateway & Acer \\
\hline G10082602 & Gateway & Acer \\
\hline G10082602 & Gateway & Acer \\
\hline G10082602 & Gateway & Acer \\
\hline G10082602 & Gateway & Acer \\
\hline G10082602 & Gateway & Acer \\
\hline G10082602 & Gateway & Acer \\
\hline G10082602 & Gateway & Acer \\
\hline G10082602 & Gateway & Acer \\
\hline G10082602 & Gateway & Acer \\
\hline G10082602 & Gateway & Pseudotsuga \\
\hline G10082602 & Gateway & Quercus \\
\hline G10082602 & Gateway & Pseudotsuga \\
\hline G10082602 & Gateway & Acer \\
\hline
\end{tabular}




\begin{tabular}{|c|c|c|}
\hline G10082602 & Gateway & Pseudotsuga \\
\hline G10082602 & Gateway & Acer \\
\hline G10082602 & Gateway & Quercus \\
\hline G10082602 & Gateway & Acer \\
\hline G10082602 & Gateway & Pseudotsuga \\
\hline G10082602 & Gateway & Pseudotsuga \\
\hline G10082602 & Gateway & Pseudotsuga \\
\hline G10082602 & Gateway & Cedrus \\
\hline G10082602 & Gateway & Pseudotsuga \\
\hline G10082602 & Gateway & Cornus \\
\hline G10082701 & Gateway & Quercus \\
\hline G10082701 & Gateway & Quercus \\
\hline G10082701 & Gateway & Pinus \\
\hline G10082701 & Gateway & Pinus \\
\hline G10082701 & Gateway & Quercus \\
\hline G10082702 & Gateway & Acer \\
\hline G10082702 & Gateway & Quercus \\
\hline G10082703 & Gateway & Quercus \\
\hline G10082703 & Gateway & Betula \\
\hline G10082703 & Gateway & Betula \\
\hline G10082703 & Gateway & Prunus \\
\hline G10082704 & Gateway & Quercus \\
\hline G10082704 & Gateway & Cedrus \\
\hline G10082704 & Gateway & Quercus \\
\hline G10082704 & Gateway & Juniperus \\
\hline G10082704 & Gateway & Pinus \\
\hline G10082704 & Gateway & Prunus \\
\hline G10082704 & Gateway & Betula \\
\hline G10082704 & Gateway & Quercus \\
\hline G10082704 & Gateway & Pinus \\
\hline G10082704 & Gateway & Pinus \\
\hline G10082704 & Gateway & Betula \\
\hline G10082704 & Gateway & Pinus \\
\hline G10082704 & Gateway & Prunus \\
\hline G10082704 & Gateway & Rhododendron \\
\hline G10082704 & Gateway & Rhododendron \\
\hline G10082704 & Gateway & Rhododendron \\
\hline G10082704 & Gateway & Rhododendron \\
\hline G10082704 & Gateway & Rhododendron \\
\hline G10082704 & Gateway & Ilex \\
\hline G10082704 & Gateway & Ilex \\
\hline G10082704 & Gateway & Ilex \\
\hline G10082704 & Gateway & Ilex \\
\hline G10082704 & Gateway & Ilex \\
\hline G10082704 & Gateway & Ilex \\
\hline
\end{tabular}




\begin{tabular}{|c|c|c|}
\hline G10082704 & Gateway & Ilex \\
\hline G10082704 & Gateway & Prunus \\
\hline G10082704 & Gateway & Prunus \\
\hline G10082704 & Gateway & Rhododendron \\
\hline G10083001 & Gateway & Quercus \\
\hline G10083001 & Gateway & Quercus \\
\hline G10083001 & Gateway & Populus \\
\hline G10083001 & Gateway & Quercus \\
\hline G10083001 & Gateway & Berberis \\
\hline G10083001 & Gateway & Berberis \\
\hline G10083001 & Gateway & Rosa \\
\hline G10083001 & Gateway & Rosa \\
\hline G10083001 & Gateway & Rosa \\
\hline G10083001 & Gateway & Rosa \\
\hline G10083001 & Gateway & Rosa \\
\hline G10083001 & Gateway & Rosa \\
\hline G10083001 & Gateway & Rosa \\
\hline G10083001 & Gateway & Rosa \\
\hline G10083001 & Gateway & Rosa \\
\hline G10083001 & Gateway & Rosa \\
\hline G10083001 & Gateway & Rosa \\
\hline G10083001 & Gateway & Rosa \\
\hline G10083001 & Gateway & Rosa \\
\hline G10083001 & Gateway & Rosa \\
\hline G10083001 & Gateway & Rosa \\
\hline G10083001 & Gateway & Rosa \\
\hline G10083001 & Gateway & Rosa \\
\hline G10083002 & Gateway & Acer \\
\hline G10083002 & Gateway & Acer \\
\hline G10083002 & Gateway & Acer \\
\hline G10083002 & Gateway & Acer \\
\hline G10083002 & Gateway & Quercus \\
\hline G10083002 & Gateway & Quercus \\
\hline G10083002 & Gateway & Quercus \\
\hline G10083002 & Gateway & Quercus \\
\hline G10083002 & Gateway & Acer \\
\hline G10083002 & Gateway & Quercus \\
\hline G10083002 & Gateway & Euonymous \\
\hline G10083002 & Gateway & Euonymous \\
\hline G10083002 & Gateway & Euonymous \\
\hline G10083002 & Gateway & Euonymous \\
\hline G10083002 & Gateway & Euonymous \\
\hline G10083002 & Gateway & Euonymous \\
\hline G10083002 & Gateway & Euonymous \\
\hline G10083002 & Gateway & Euonymous \\
\hline
\end{tabular}




\begin{tabular}{|c|c|c|}
\hline G10083002 & Gateway & Euonymous \\
\hline G10083002 & Gateway & Euonymous \\
\hline G10083002 & Gateway & Euonymous \\
\hline G10083002 & Gateway & Euonymous \\
\hline G10083002 & Gateway & Euonymous \\
\hline G10083002 & Gateway & Euonymous \\
\hline G10083002 & Gateway & Euonymous \\
\hline G10083002 & Gateway & Euonymous \\
\hline G10083002 & Gateway & Euonymous \\
\hline G10083002 & Gateway & Euonymous \\
\hline G10083002 & Gateway & Euonymous \\
\hline G10083002 & Gateway & Euonymous \\
\hline G10083002 & Gateway & Euonymous \\
\hline G10083002 & Gateway & Euonymous \\
\hline G10083002 & Gateway & Euonymous \\
\hline G10083002 & Gateway & Euonymous \\
\hline G10083002 & Gateway & Euonymous \\
\hline G10083002 & Gateway & Euonymous \\
\hline G10083002 & Gateway & Euonymous \\
\hline G10083002 & Gateway & Euonymous \\
\hline G10083002 & Gateway & Euonymous \\
\hline G10083002 & Gateway & Euonymous \\
\hline G10083002 & Gateway & Euonymous \\
\hline G10083002 & Gateway & Euonymous \\
\hline G10083002 & Gateway & Euonymous \\
\hline G10083002 & Gateway & Euonymous \\
\hline G10083002 & Gateway & Euonymous \\
\hline G10083002 & Gateway & Euonymous \\
\hline G10083002 & Gateway & Euonymous \\
\hline G10083002 & Gateway & Euonymous \\
\hline G10083002 & Gateway & Euonymous \\
\hline G10083002 & Gateway & Euonymous \\
\hline G10083002 & Gateway & Euonymous \\
\hline G10083002 & Gateway & Euonymous \\
\hline G10083002 & Gateway & Prunus \\
\hline G10083002 & Gateway & Prunus \\
\hline G10083002 & Gateway & Prunus \\
\hline G10083002 & Gateway & Prunus \\
\hline G10083002 & Gateway & Prunus \\
\hline G10083002 & Gateway & Prunus \\
\hline G10083002 & Gateway & Prunus \\
\hline G10083002 & Gateway & Prunus \\
\hline G10083002 & Gateway & Prunus \\
\hline G10083002 & Gateway & Prunus \\
\hline G10083002 & Gateway & Prunus \\
\hline
\end{tabular}




\begin{tabular}{|c|c|c|}
\hline G10083002 & Gateway & Prunus \\
\hline G10083002 & Gateway & Prunus \\
\hline G10083002 & Gateway & Prunus \\
\hline G10083002 & Gateway & Prunus \\
\hline G10083002 & Gateway & Prunus \\
\hline G10083002 & Gateway & Prunus \\
\hline G10083002 & Gateway & Prunus \\
\hline G10083002 & Gateway & Prunus \\
\hline G10083002 & Gateway & Prunus \\
\hline G10083002 & Gateway & Prunus \\
\hline G10083002 & Gateway & Prunus \\
\hline G10083003 & Gateway & Pyrus \\
\hline G10083003 & Gateway & Pyrus \\
\hline G10083003 & Gateway & Pyrus \\
\hline G10083003 & Gateway & Pyrus \\
\hline G10083003 & Gateway & Fraxinus \\
\hline G10083003 & Gateway & Thuja \\
\hline G10083003 & Gateway & Thuja \\
\hline G10083003 & Gateway & Thuja \\
\hline G10083003 & Gateway & Thuja \\
\hline G10083003 & Gateway & Thuja \\
\hline G10083003 & Gateway & Pinus \\
\hline G10083003 & Gateway & Pinus \\
\hline G10083003 & Gateway & Pinus \\
\hline G10083003 & Gateway & Pinus \\
\hline G10083003 & Gateway & Photinia \\
\hline G10083003 & Gateway & Viburnum \\
\hline G10083003 & Gateway & Pseudotsuga \\
\hline G10083004 & Gateway & Acer \\
\hline G10083004 & Gateway & Pseudotsuga \\
\hline G10083004 & Gateway & Pseudotsuga \\
\hline G10083004 & Gateway & Pinus \\
\hline G10083004 & Gateway & Castanea \\
\hline G10083004 & Gateway & Pyrus \\
\hline G10083004 & Gateway & Pyrus \\
\hline G10083004 & Gateway & Thuja \\
\hline G10083004 & Gateway & Thuja \\
\hline G10083004 & Gateway & Thuja \\
\hline G10083004 & Gateway & Thuja \\
\hline G10083004 & Gateway & Thuja \\
\hline G10083004 & Gateway & Thuja \\
\hline G10083004 & Gateway & Thuja \\
\hline G10083004 & Gateway & Thuja \\
\hline G10083004 & Gateway & Thuja \\
\hline G10083004 & Gateway & Thuja \\
\hline
\end{tabular}




\begin{tabular}{|c|c|c|}
\hline G10083004 & Gateway & Thuja \\
\hline G10083004 & Gateway & Thuja \\
\hline G10083004 & Gateway & Thuja \\
\hline G10083004 & Gateway & Thuja \\
\hline G10083004 & Gateway & Thuja \\
\hline G10083004 & Gateway & Thuja \\
\hline G10083004 & Gateway & Thuja \\
\hline G10083004 & Gateway & Thuja \\
\hline G10083004 & Gateway & Thuja \\
\hline G10083004 & Gateway & Thuja \\
\hline G10083004 & Gateway & Thuja \\
\hline G10083004 & Gateway & Thuja \\
\hline G10083004 & Gateway & Robinia \\
\hline G10083004 & Gateway & Robinia \\
\hline G10083004 & Gateway & Robinia \\
\hline G10083004 & Gateway & Robinia \\
\hline G10083004 & Gateway & Robinia \\
\hline G10083004 & Gateway & Robinia \\
\hline G10083004 & Gateway & Robinia \\
\hline G10083004 & Gateway & Robinia \\
\hline G10083004 & Gateway & Robinia \\
\hline G10083004 & Gateway & Robinia \\
\hline G10083004 & Gateway & Robinia \\
\hline G10083004 & Gateway & Robinia \\
\hline G10083004 & Gateway & Rosa \\
\hline G10083004 & Gateway & Rosa \\
\hline G10083004 & Gateway & Picea \\
\hline G10083004 & Gateway & Prunus \\
\hline G10083004 & Gateway & Prunus \\
\hline G10083004 & Gateway & Prunus \\
\hline G10083004 & Gateway & Pieris \\
\hline G10083004 & Gateway & Rosa \\
\hline G10083004 & Gateway & Pieris \\
\hline G10083004 & Gateway & Pieris \\
\hline G10083004 & Gateway & Pieris \\
\hline G10083004 & Gateway & Pieris \\
\hline G10083004 & Gateway & Pieris \\
\hline G10083004 & Gateway & Pieris \\
\hline G10083004 & Gateway & Pieris \\
\hline G10083004 & Gateway & Pieris \\
\hline G10083004 & Gateway & Pieris \\
\hline G10083004 & Gateway & Pieris \\
\hline G10083004 & Gateway & Pieris \\
\hline G10083004 & Gateway & Pieris \\
\hline G10083101 & Gateway & Thuja \\
\hline
\end{tabular}




\begin{tabular}{|c|c|c|}
\hline G10083101 & Gateway & Thuja \\
\hline G10083101 & Gateway & Rhododendro \\
\hline G10083101 & Gateway & Rhododendron \\
\hline G10083101 & Gateway & Rhododendron \\
\hline G10083101 & Gateway & Rhododendron \\
\hline G10083101 & Gateway & Rhododendro \\
\hline G10083101 & Gateway & Rhododendron \\
\hline G10083101 & Gateway & Rhododendron \\
\hline G10083101 & Gateway & Acer \\
\hline G10083101 & Gateway & Rhododendron \\
\hline G10083101 & Gateway & Rhododendron \\
\hline G10083101 & Gateway & Rhododendron \\
\hline G10083101 & Gateway & Rhododendron \\
\hline G10083101 & Gateway & Rhododendron \\
\hline G10083101 & Gateway & Rhododendron \\
\hline G10083101 & Gateway & Rhododendron \\
\hline G10083101 & Gateway & Rhododendron \\
\hline G10083101 & Gateway & Rhododendron \\
\hline G10083101 & Gateway & Rhododendron \\
\hline G10083101 & Gateway & Rhododendron \\
\hline G10083101 & Gateway & Rhododendron \\
\hline G10083101 & Gateway & Acer \\
\hline G10083101 & Gateway & Pieris \\
\hline G10083101 & Gateway & Pieris \\
\hline G10083101 & Gateway & Pieris \\
\hline G10083101 & Gateway & Rhododendron \\
\hline G10083101 & Gateway & Rhododendron \\
\hline G10083101 & Gateway & Rhododendron \\
\hline G10083101 & Gateway & Rhododendron \\
\hline G10083101 & Gateway & Pieris \\
\hline G10083101 & Gateway & Ilex \\
\hline G10083101 & Gateway & Juniperus \\
\hline G10083101 & Gateway & Ilex \\
\hline G10083101 & Gateway & Ilex \\
\hline G10083101 & Gateway & Juniperus \\
\hline G10083101 & Gateway & Ilex \\
\hline G10083101 & Gateway & Ilex \\
\hline G10083101 & Gateway & Ilex \\
\hline G10083101 & Gateway & Juniperus \\
\hline G10083101 & Gateway & Ilex \\
\hline G10083101 & Gateway & Ilex \\
\hline G10083101 & Gateway & Pieris \\
\hline G10083101 & Gateway & Pieris \\
\hline G10083101 & Gateway & Pieris \\
\hline G10083101 & Gateway & Erica \\
\hline
\end{tabular}




$\begin{array}{llc}\text { G10083101 } & \text { Gateway } & \text { Erica } \\ \text { G10083101 } & \text { Gateway } & \text { Prunus } \\ \text { G10083101 } & \text { Gateway } & \text { Pieris } \\ \text { G10083101 } & \text { Gateway } & \text { Pieris } \\ \text { G10083101 } & \text { Gateway } & \text { Rhododendron } \\ \text { G10083101 } & \text { Gateway } & \text { Rhododendron } \\ \text { G10083101 } & \text { Gateway } & \text { Rhododendron } \\ \text { G10083101 } & \text { Gateway } & \text { Rhododendron } \\ \text { G10083101 } & \text { Gateway } & \text { Rhododendron } \\ \text { G10083101 } & \text { Gateway } & \text { Rhododendron } \\ \text { G10083101 } & \text { Gateway } & \text { Cedrus } \\ \text { G10083101 } & \text { Gateway } & \text { Cedrus } \\ \text { G10083101 } & \text { Gateway } & \text { Cedrus } \\ \text { G10083101 } & \text { Gateway } & \text { Cedrus } \\ \text { G10083101 } & \text { Gateway } & \text { Polygonium } \\ \text { G10083101 } & \text { Gateway } & \text { Cedrus } \\ \text { G10083101 } & \text { Gateway } & \text { Juniperus } \\ \text { G10083101 } & \text { Gateway } & \text { Juniperus } \\ \text { G10083101 } & \text { Gateway } & \text { Juniperus } \\ \text { G10083101 } & \text { Gateway } & \text { Juniperus } \\ \text { G10083101 } & \text { Gateway } & \text { Daphne } \\ \text { G10083101 } & \text { Gateway } & \text { Daphne } \\ \text { G10083101 } & \text { Gateway } & \text { Pinus } \\ \text { G10083101 } & \text { Gateway } & \text { Pinus } \\ \text { G10083101 } & \text { Gateway } & \text { Pinus } \\ \text { G10083101 } & \text { Gateway } & \text { Rhododendron } \\ \text { G10090201 } & \text { Gateway } & \text { Pyrus } \\ \text { G10090201 } & \text { Gateway } & \text { Pyrus } \\ \text { G10090201 } & \text { Gateway } & \text { Pyrus } \\ \text { G10090201 } & \text { Gateway } & \text { Crataegus } \\ \text { G10090201 } & \text { Gateway } & \text { Hydrangea } \\ \text { G10090201 } & \text { Gateway } & \text { Rhododendron } \\ \text { G10090201 } & \text { Gateway } & \text { Rhododendron } \\ \text { G10090201 } & \text { Gateway } & \text { Hamamelis } \\ \text { G10090201 } & \text { Gateway } & \text { Hamamelis } \\ \text { G10090201 } & \text { Gateway } & \text { Hydrangea } \\ \text { G10090201 } & \text { Gateway } & \text { Hamamelis } \\ \text { G10090201 } & \text { Gateway } & \text { Myrica } \\ \text { Gyrica } \\ \text { Gatewica }\end{array}$




\begin{tabular}{|c|c|c|}
\hline G10090201 & Gateway & Myrica \\
\hline G10090201 & Gateway & Myrica \\
\hline G10090201 & Gateway & Myrica \\
\hline G10090201 & Gateway & Myrica \\
\hline G10090201 & Gateway & Myrica \\
\hline G10090201 & Gateway & Myrica \\
\hline G10090201 & Gateway & Myrica \\
\hline G10090201 & Gateway & Myrica \\
\hline G10090201 & Gateway & Myrica \\
\hline G10090201 & Gateway & Myrica \\
\hline G10090201 & Gateway & Myrica \\
\hline G10090201 & Gateway & Myrica \\
\hline G10090201 & Gateway & Myrica \\
\hline G10090201 & Gateway & Myrica \\
\hline G10090201 & Gateway & Myrica \\
\hline G10090201 & Gateway & Myrica \\
\hline G10090201 & Gateway & Hamamelis \\
\hline G10090201 & Gateway & Hydrangea \\
\hline G10090201 & Gateway & Rhododendron \\
\hline G10090201 & Gateway & Ligustrum \\
\hline G10090201 & Gateway & Ligustrum \\
\hline G10090201 & Gateway & Ligustrum \\
\hline G10090201 & Gateway & Ligustrum \\
\hline G10090201 & Gateway & Ligustrum \\
\hline G10090201 & Gateway & Ligustrum \\
\hline G10090201 & Gateway & Rhododendron \\
\hline G10090201 & Gateway & Ligustrum \\
\hline G10090201 & Gateway & Ligustrum \\
\hline G10090201 & Gateway & Rhododendron \\
\hline G10090201 & Gateway & Rhododendron \\
\hline G10090201 & Gateway & Rhododendron \\
\hline G10090201 & Gateway & Rhododendron \\
\hline G10090201 & Gateway & Rhododendron \\
\hline G10090201 & Gateway & Rhododendron \\
\hline G10090201 & Gateway & Ilex \\
\hline G10090201 & Gateway & Ilex \\
\hline G10090201 & Gateway & Ilex \\
\hline G10090201 & Gateway & Ilex \\
\hline G10090201 & Gateway & Ilex \\
\hline G10090201 & Gateway & Ilex \\
\hline G10090201 & Gateway & Ilex \\
\hline G10090201 & Gateway & Ilex \\
\hline G10090201 & Gateway & Ilex \\
\hline G10090201 & Gateway & Ligustrum \\
\hline G10090201 & Gateway & Hydrangea \\
\hline
\end{tabular}




$\begin{array}{llc}\text { G10090202 } & \text { Gateway } & \text { Ginkgo } \\ \text { G10090202 } & \text { Gateway } & \text { Fraxinus } \\ \text { G10090202 } & \text { Gateway } & \text { Fraxinus } \\ \text { G10090202 } & \text { Gateway } & \text { Acer } \\ \text { G10090202 } & \text { Gateway } & \text { Thuja } \\ \text { G10090202 } & \text { Gateway } & \text { Cornus } \\ \text { G10090202 } & \text { Gateway } & \text { Cornus } \\ \text { G10090202 } & \text { Gateway } & \text { Cornus } \\ \text { G10090202 } & \text { Gateway } & \text { Cornus } \\ \text { G10090202 } & \text { Gateway } & \text { Cornus } \\ \text { G10090202 } & \text { Gateway } & \text { Cornus } \\ \text { G10090202 } & \text { Gateway } & \text { Cornus } \\ \text { G10090202 } & \text { Gateway } & \text { Cornus } \\ \text { G10090202 } & \text { Gateway } & \text { Cornus } \\ \text { G10090202 } & \text { Gateway } & \text { Cornus } \\ \text { G10090202 } & \text { Gateway } & \text { Cornus } \\ \text { G10090202 } & \text { Gateway } & \text { Cornus } \\ \text { G10090202 } & \text { Gateway } & \text { Cornus } \\ \text { G10090202 } & \text { Gateway } & \text { Cornus } \\ \text { G10090202 } & \text { Gateway } & \text { Potentilla } \\ \text { G10090202 } & \text { Gateway } & \text { Prunus } \\ \text { G10090202 } & \text { Gateway } & \text { Ailanthus } \\ \text { G10090202 } & \text { Gateway } & \text { Paulownia } \\ \text { G10090301 } & \text { Gateway } & \text { Acer } \\ \text { G10090301 } & \text { Gateway } & \text { Acer } \\ \text { G10090301 } & \text { Gateway } & \text { Acer } \\ \text { G10090301 } & \text { Gateway } & \text { Prunus } \\ \text { G10090301 } & \text { Gateway } & \text { Prunus } \\ \text { G10090301 } & \text { Gateway } & \text { Prunus } \\ \text { G10090301 } & \text { Gateway } & \text { Prunus } \\ \text { G10090301 } & \text { Gateway } & \text { Prunus } \\ \text { G10090309030100303 } & \text { Gateway } & \text { Prunus } \\ \text { G10090301 } & \text { Gateway } & \text { Ilex } \\ \text { G10090301 } & \text { Gateway } & \text { Ilex } \\ \text { G10090301 } & \text { Gateway } & \text { Ilex } \\ \text { Glex } \\ \text { Gateway }\end{array}$




\begin{tabular}{|c|c|c|}
\hline G10090303 & Gateway & Prunus \\
\hline G10090303 & Gateway & Photinia \\
\hline G10090303 & Gateway & Bamboo \\
\hline G10090303 & Gateway & Acer \\
\hline G10090303 & Gateway & Acer \\
\hline G10090303 & Gateway & Juniperus \\
\hline G10090303 & Gateway & Juniperus \\
\hline G10090303 & Gateway & Juniperus \\
\hline G10090303 & Gateway & Juniperus \\
\hline G10090303 & Gateway & Juniperus \\
\hline G10090303 & Gateway & Juniperus \\
\hline G10090303 & Gateway & Juniperus \\
\hline G10090303 & Gateway & Juniperus \\
\hline G10090303 & Gateway & Juniperus \\
\hline G10090303 & Gateway & Juniperus \\
\hline G10090303 & Gateway & Juniperus \\
\hline G10090303 & Gateway & Juniperus \\
\hline G10090303 & Gateway & Juniperus \\
\hline G10090303 & Gateway & Juniperus \\
\hline G10090303 & Gateway & Juniperus \\
\hline G10090303 & Gateway & Juniperus \\
\hline G10090303 & Gateway & Juniperus \\
\hline G10090303 & Gateway & Bamboo \\
\hline G10090303 & Gateway & Pyrus \\
\hline G10090303 & Gateway & Acer \\
\hline G10090303 & Gateway & Bamboo \\
\hline G10090303 & Gateway & Photinia \\
\hline G10090303 & Gateway & Photinia \\
\hline G10090303 & Gateway & Photinia \\
\hline G10090304 & Gateway & Pseudotsuga \\
\hline G10090304 & Gateway & Pseudotsuga \\
\hline G10090304 & Gateway & Pseudotsuga \\
\hline G10090304 & Gateway & Pseudotsuga \\
\hline G10090304 & Gateway & Pseudotsuga \\
\hline G10090304 & Gateway & Robinia \\
\hline G10090304 & Gateway & Robinia \\
\hline G10090304 & Gateway & Robinia \\
\hline G10090304 & Gateway & Buxus \\
\hline G10090304 & Gateway & Buxus \\
\hline G10090304 & Gateway & Buxus \\
\hline G10090304 & Gateway & Syringa \\
\hline G10090304 & Gateway & Malus \\
\hline G10090304 & Gateway & Pyrus \\
\hline G10090304 & Gateway & Thuja \\
\hline G10090304 & Gateway & Prunus \\
\hline
\end{tabular}




\begin{tabular}{|c|c|c|}
\hline G10090304 & Gateway & Prunus \\
\hline G10090304 & Gateway & Buxus \\
\hline G10090304 & Gateway & Buxus \\
\hline G10090304 & Gateway & Rhododendron \\
\hline G10090304 & Gateway & Rhododendron \\
\hline G10090304 & Gateway & Buxus \\
\hline G10090601 & Gateway & Thuja \\
\hline G10090601 & Gateway & Thuja \\
\hline G10090601 & Gateway & Acer \\
\hline G10090601 & Gateway & Acer \\
\hline G10090601 & Gateway & Acer \\
\hline G10090601 & Gateway & Acer \\
\hline G10090601 & Gateway & Thuja \\
\hline G10090601 & Gateway & Cedrus \\
\hline G10090601 & Gateway & Pseudotsuga \\
\hline G10090601 & Gateway & Pseudotsuga \\
\hline G10090601 & Gateway & Prunus \\
\hline G10090601 & Gateway & Pseudotsuga \\
\hline G10090601 & Gateway & Acer \\
\hline G10090601 & Gateway & Pseudotsuga \\
\hline G10090601 & Gateway & Pseudotsuga \\
\hline G10090601 & Gateway & Pseudotsuga \\
\hline G10090601 & Gateway & Pseudotsuga \\
\hline G10090601 & Gateway & Pseudotsuga \\
\hline G10090601 & Gateway & Pseudotsuga \\
\hline G10090601 & Gateway & Pseudotsuga \\
\hline G10090601 & Gateway & Cedrus \\
\hline G10090601 & Gateway & Pseudotsuga \\
\hline G10090601 & Gateway & Pseudotsuga \\
\hline G10090601 & Gateway & Pseudotsuga \\
\hline G10090601 & Gateway & Pseudotsuga \\
\hline G10090601 & Gateway & Pseudotsuga \\
\hline G10090601 & Gateway & Cedrus \\
\hline G10090601 & Gateway & Cedrus \\
\hline G10090601 & Gateway & Prunus \\
\hline G10090601 & Gateway & Prunus \\
\hline G10090601 & Gateway & Cedrus \\
\hline G10090602 & Gateway & Liquidambar \\
\hline G10090602 & Gateway & Liquidambar \\
\hline G10090602 & Gateway & Quercus \\
\hline G10090602 & Gateway & Potentilla \\
\hline G10090602 & Gateway & Ilex \\
\hline G10090602 & Gateway & Ilex \\
\hline G10090602 & Gateway & Sorbus \\
\hline G10090602 & Gateway & Ilex \\
\hline
\end{tabular}




\begin{tabular}{|c|c|c|}
\hline G10090602 & Gateway & Sorbus \\
\hline G10090602 & Gateway & Thuja \\
\hline G10090602 & Gateway & Potentilla \\
\hline G10090602 & Gateway & Potentilla \\
\hline G10090602 & Gateway & Thuja \\
\hline G10090602 & Gateway & Thuja \\
\hline G10090602 & Gateway & Thuja \\
\hline G10090602 & Gateway & Potentilla \\
\hline G10090602 & Gateway & Potentilla \\
\hline G10090602 & Gateway & Rhododendron \\
\hline G10090602 & Gateway & Thuja \\
\hline G10090602 & Gateway & Rhododendron \\
\hline G10090602 & Gateway & Thuja \\
\hline G10090602 & Gateway & Rhododendron \\
\hline G10090602 & Gateway & Mahonia \\
\hline G10090602 & Gateway & Ilex \\
\hline G10090602 & Gateway & Rhododendron \\
\hline G10090602 & Gateway & Rhododendron \\
\hline G10090602 & Gateway & Rhododendron \\
\hline G10090602 & Gateway & Rhododendron \\
\hline G10090602 & Gateway & Rhododendron \\
\hline G10090602 & Gateway & Mahonia \\
\hline G10090602 & Gateway & Buxus \\
\hline G10090602 & Gateway & Buxus \\
\hline G10090602 & Gateway & Nandina \\
\hline G10090602 & Gateway & Nandina \\
\hline G10090602 & Gateway & Buxus \\
\hline G10090602 & Gateway & Buxus \\
\hline G10090602 & Gateway & Rhododendron \\
\hline G10090602 & Gateway & Berberis \\
\hline G10090602 & Gateway & Berberis \\
\hline G10090602 & Gateway & Berberis \\
\hline G10090602 & Gateway & Berberis \\
\hline G10090602 & Gateway & Berberis \\
\hline G10090602 & Gateway & Berberis \\
\hline G10090602 & Gateway & Berberis \\
\hline G10090602 & Gateway & Berberis \\
\hline G10090602 & Gateway & Berberis \\
\hline G10090602 & Gateway & Berberis \\
\hline G10090602 & Gateway & Berberis \\
\hline G10090602 & Gateway & Berberis \\
\hline G10090602 & Gateway & Berberis \\
\hline G10090602 & Gateway & Berberis \\
\hline G10090602 & Gateway & Berberis \\
\hline G10090602 & Gateway & Berberis \\
\hline
\end{tabular}




\begin{tabular}{|c|c|c|}
\hline G10090602 & Gateway & Berberis \\
\hline G10090602 & Gateway & Berberis \\
\hline G10090602 & Gateway & Berberis \\
\hline G10090602 & Gateway & Berberis \\
\hline L10090701 & Lents & Crataegus \\
\hline L10090701 & Lents & Crataegus \\
\hline L10090701 & Lents & Rhododendron \\
\hline L10090701 & Lents & Rhododendron \\
\hline L10090701 & Lents & Rhododendron \\
\hline L10090701 & Lents & Pinus \\
\hline L10090701 & Lents & Pinus \\
\hline L10090701 & Lents & Thuja \\
\hline L10090701 & Lents & Cedrus \\
\hline L10090701 & Lents & Unknown 2 \\
\hline L10090701 & Lents & Pseudotsuga \\
\hline L10090701 & Lents & Cedrus \\
\hline L10090701 & Lents & Pinus \\
\hline L10090701 & Lents & Pinus \\
\hline L10090701 & Lents & Cedrus \\
\hline L10090701 & Lents & Pinus \\
\hline L10090701 & Lents & Cedrus \\
\hline L10090701 & Lents & Cedrus \\
\hline L10090701 & Lents & Pinus \\
\hline L10090701 & Lents & Cedrus \\
\hline L10090701 & Lents & Pinus \\
\hline L10090701 & Lents & Cedrus \\
\hline L10090701 & Lents & Cedrus \\
\hline L10090701 & Lents & Calocedrus \\
\hline L10090701 & Lents & Crataegus \\
\hline L10090701 & Lents & Crataegus \\
\hline L10090701 & Lents & Crataegus \\
\hline L10090702 & Lents & Pseudotsuga \\
\hline L10090702 & Lents & Pseudotsuga \\
\hline L10090702 & Lents & Acer \\
\hline L10090702 & Lents & Acer \\
\hline L10090702 & Lents & Myrica \\
\hline L10090702 & Lents & Unknown 1 \\
\hline L10090702 & Lents & Abelia \\
\hline L10090702 & Lents & Abelia \\
\hline L10090702 & Lents & Abelia \\
\hline L10090702 & Lents & Abelia \\
\hline L10090702 & Lents & Abelia \\
\hline L10090702 & Lents & Abelia \\
\hline L10090702 & Lents & Abelia \\
\hline L10090702 & Lents & Abelia \\
\hline
\end{tabular}




\begin{tabular}{|c|c|c|}
\hline L10090702 & Lents & Abelia \\
\hline L10090702 & Lents & Abelia \\
\hline L10090702 & Lents & Abelia \\
\hline L10090702 & Lents & Ailanthus \\
\hline L10090702 & Lents & Ailanthus \\
\hline L10090702 & Lents & Abelia \\
\hline L10090702 & Lents & Ailanthus \\
\hline L10090702 & Lents & Abelia \\
\hline L10090702 & Lents & Abelia \\
\hline L10090702 & Lents & Abelia \\
\hline L10090702 & Lents & Abelia \\
\hline L10090702 & Lents & Ailanthus \\
\hline L10090702 & Lents & Pinus \\
\hline L10090702 & Lents & Abelia \\
\hline L10090702 & Lents & Abelia \\
\hline L10090702 & Lents & Abelia \\
\hline L10090702 & Lents & Abelia \\
\hline L10090702 & Lents & Abelia \\
\hline L10090702 & Lents & Abelia \\
\hline L10090702 & Lents & Abelia \\
\hline L10090702 & Lents & Myrica \\
\hline L10090702 & Lents & Myrica \\
\hline L10090702 & Lents & Myrica \\
\hline L10090702 & Lents & Myrica \\
\hline L10090702 & Lents & Myrica \\
\hline L10090702 & Lents & Myrica \\
\hline L10090702 & Lents & Abelia \\
\hline L10090702 & Lents & Abelia \\
\hline L10090702 & Lents & Abelia \\
\hline L10090702 & Lents & Abelia \\
\hline L10090702 & Lents & Abelia \\
\hline L10090702 & Lents & Abelia \\
\hline L10090702 & Lents & Abelia \\
\hline L10090702 & Lents & Abelia \\
\hline L10090702 & Lents & Abelia \\
\hline L10090702 & Lents & Abelia \\
\hline L10090702 & Lents & Abelia \\
\hline L10090702 & Lents & Abelia \\
\hline L10090702 & Lents & Abelia \\
\hline L10090702 & Lents & Abelia \\
\hline L10090702 & Lents & Abelia \\
\hline L10090702 & Lents & Abelia \\
\hline L10090702 & Lents & Abelia \\
\hline L10090702 & Lents & Abelia \\
\hline L10090702 & Lents & Abelia \\
\hline
\end{tabular}




$\begin{array}{lll}\text { L10090702 } & \text { Lents } & \text { Abelia } \\ \text { L10090702 } & \text { Lents } & \text { Abelia } \\ \text { L10090702 } & \text { Lents } & \text { Abelia } \\ \text { L10090702 } & \text { Lents } & \text { Abelia } \\ \text { L10090702 } & \text { Lents } & \text { Abelia } \\ \text { L10090702 } & \text { Lents } & \text { Abelia } \\ \text { L10090702 } & \text { Lents } & \text { Abelia } \\ \text { L10090702 } & \text { Lents } & \text { Abelia } \\ \text { L10090702 } & \text { Lents } & \text { Abelia } \\ \text { L10090702 } & \text { Lents } & \text { Abelia } \\ \text { L10090702 } & \text { Lents } & \text { Abelia } \\ \text { L10090702 } & \text { Lents } & \text { Abelia } \\ \text { L10090702 } & \text { Lents } & \text { Abelia } \\ \text { L10090702 } & \text { Lents } & \text { Abelia } \\ \text { L10090702 } & \text { Lents } & \text { Abelia } \\ \text { L10090702 } & \text { Lents } & \text { Abelia } \\ \text { L10090702 } & \text { Lents } & \text { Abelia } \\ \text { L10090702 } & \text { Lents } & \text { Abelia } \\ \text { L10090702 } & \text { Lents } & \text { Abelia } \\ \text { L10090702 } & \text { Lents } & \text { Abelia } \\ \text { L10090702 } & \text { Lents } & \text { Abelia } \\ \text { L10090702 } & \text { Lents } & \text { Abelia } \\ \text { L10090702 } & \text { Lents } & \text { Abelia } \\ \text { L10090702 } & \text { Lents } & \text { Abelia } \\ \text { L10090702 } & \text { Lents } & \text { Abelia } \\ \text { L10090702 } 1009070702 & \text { Lents } & \text { Abelia } \\ \text { L10090702 } & \text { Lents } & \text { Abelia } \\ \text { L10090702 } & \text { Lents } & \text { Abelia } \\ \text { L10090702 } & \text { Lents } & \text { Abelia } \\ \text { L10090702 } & \text { Lents } & \text { Abelia } \\ \text { L10090702 } 100909070702 & \text { Lents } & \text { Abelia } \\ \text { L10090702 } & \text { Lents } & \text { Abelia } \\ \text { L10090702 } & \text { Lents } & \text { Abelia } \\ \text { L10090702 } & \text { Lents } & \text { Abelia } \\ \text { L10090702 } & \text { Lents } & \text { Abelia } \\ \text { Lents } & \text { Lents } & \text { Abelia } \\ \text { Lents } & \text { Lents } & \text { Abelia } \\ \text { Lents } & \text { Abelia } \\ \text { Lelia } \\ \text { Lents }\end{array}$




\begin{tabular}{|c|c|c|}
\hline L10090702 & Lents & Abelia \\
\hline L10090702 & Lents & Abelia \\
\hline L10090702 & Lents & Abelia \\
\hline L10090702 & Lents & Abelia \\
\hline L10090702 & Lents & Abelia \\
\hline L10090702 & Lents & Abelia \\
\hline L10090702 & Lents & Abelia \\
\hline L10090702 & Lents & Abelia \\
\hline L10090702 & Lents & Abelia \\
\hline L10090702 & Lents & Abelia \\
\hline L10090702 & Lents & Abelia \\
\hline L10090702 & Lents & Abelia \\
\hline L10090702 & Lents & Abelia \\
\hline L10090702 & Lents & Abelia \\
\hline L10090702 & Lents & Abelia \\
\hline L10090702 & Lents & Abelia \\
\hline L10090702 & Lents & Abelia \\
\hline L10090702 & Lents & Abelia \\
\hline L10090702 & Lents & Abelia \\
\hline L10090702 & Lents & Abelia \\
\hline L10090702 & Lents & Abelia \\
\hline L10090702 & Lents & Abelia \\
\hline L10090702 & Lents & Abelia \\
\hline L10090702 & Lents & Abelia \\
\hline L10090702 & Lents & Abelia \\
\hline L10090702 & Lents & Abelia \\
\hline L10090702 & Lents & Abelia \\
\hline L10090702 & Lents & Abelia \\
\hline L10090702 & Lents & Abelia \\
\hline L10090702 & Lents & Abelia \\
\hline L10090702 & Lents & Abelia \\
\hline L10090702 & Lents & Abelia \\
\hline L10090702 & Lents & Abelia \\
\hline L10090702 & Lents & Abelia \\
\hline L10090703 & Lents & $N A$ \\
\hline L10090901 & Lents & Crataegus \\
\hline L10090901 & Lents & Rosa \\
\hline L10090901 & Lents & Salix \\
\hline L10090901 & Lents & Camellia \\
\hline L10090901 & Lents & Ailanthus \\
\hline L10090901 & Lents & Rhododendron \\
\hline L10090901 & Lents & Hydrangea \\
\hline L10090901 & Lents & Juniperus \\
\hline L10090901 & Lents & Syringa \\
\hline L10090901 & Lents & Juniperus \\
\hline
\end{tabular}




\begin{tabular}{|c|c|c|}
\hline L10090901 & Lents & Rosa \\
\hline L10090901 & Lents & Symphoricarpos \\
\hline L10090901 & Lents & Spirea \\
\hline L10090901 & Lents & Symphoricarpos \\
\hline L10090901 & Lents & Symphoricarpos \\
\hline L10090901 & Lents & Rosa \\
\hline L10090901 & Lents & Cupressus \\
\hline L10090901 & Lents & Cupressus \\
\hline L10090901 & Lents & Cupressus \\
\hline L10090901 & Lents & Picea \\
\hline L10090901 & Lents & Rosa \\
\hline L10090901 & Lents & Rosa \\
\hline L10090901 & Lents & Rosa \\
\hline L10090901 & Lents & Rosa \\
\hline L10090901 & Lents & Rosa \\
\hline L10090901 & Lents & Rosa \\
\hline L10090901 & Lents & Rhododendron \\
\hline L10090902 & Lents & Pinus \\
\hline L10090902 & Lents & Pinus \\
\hline L10090902 & Lents & Pinus \\
\hline L10090902 & Lents & Pinus \\
\hline L10090902 & Lents & Pinus \\
\hline L10090902 & Lents & Acer \\
\hline L10090902 & Lents & Pseudotsuga \\
\hline L10090902 & Lents & Sorbus \\
\hline L10090902 & Lents & Sorbus \\
\hline L10090902 & Lents & Sorbus \\
\hline L10090902 & Lents & Pinus \\
\hline L10090902 & Lents & Pseudotsuga \\
\hline L10090902 & Lents & Pseudotsuga \\
\hline L10090902 & Lents & Pinus \\
\hline L10090902 & Lents & Juniperus \\
\hline L10090902 & Lents & Acer \\
\hline L10090902 & Lents & Prunus \\
\hline L10090902 & Lents & Abelia \\
\hline L10090903 & Lents & Sorbus \\
\hline L10090903 & Lents & Acer \\
\hline L10090903 & Lents & Pseudotsuga \\
\hline L10090903 & Lents & Pseudotsuga \\
\hline L10090903 & Lents & Pseudotsuga \\
\hline L10090903 & Lents & Prunus \\
\hline L10090903 & Lents & Prunus \\
\hline L10090903 & Lents & Prunus \\
\hline L10090903 & Lents & Prunus \\
\hline L10090903 & Lents & Prunus \\
\hline
\end{tabular}




\begin{tabular}{|c|c|c|}
\hline L10090903 & Lents & Prunus \\
\hline L10090903 & Lents & Pseudotsuga \\
\hline L10090903 & Lents & Agave \\
\hline L10090904 & Lents & Larix \\
\hline L10090904 & Lents & Pinus \\
\hline L10090904 & Lents & Acer \\
\hline L10090904 & Lents & Acer \\
\hline L10090904 & Lents & Acer \\
\hline L10090904 & Lents & Pinus \\
\hline L10090904 & Lents & Pinus \\
\hline L10090904 & Lents & Acer \\
\hline L10090904 & Lents & Pinus \\
\hline L10090904 & Lents & Acer \\
\hline L10090904 & Lents & Cotoneaster \\
\hline L10090904 & Lents & Acer \\
\hline L10090904 & Lents & Cotoneaster \\
\hline L10090904 & Lents & Pinus \\
\hline L10090904 & Lents & Pinus \\
\hline L10090904 & Lents & Salix \\
\hline L10090904 & Lents & Pyrus \\
\hline L10090904 & Lents & Cotoneaster \\
\hline L10090904 & Lents & Berberis \\
\hline L10090904 & Lents & Berberis \\
\hline L10090904 & Lents & Berberis \\
\hline L10090904 & Lents & Berberis \\
\hline L10090904 & Lents & Acer \\
\hline L10090904 & Lents & Pinus \\
\hline L10090904 & Lents & Pinus \\
\hline L10090904 & Lents & Jasminum \\
\hline L10091001 & Lents & Catalpa \\
\hline L10091001 & Lents & Acer \\
\hline L10091001 & Lents & Ulmus \\
\hline L10091001 & Lents & Ligustrum \\
\hline L10091001 & Lents & Ligustrum \\
\hline L10091001 & Lents & Ligustrum \\
\hline L10091001 & Lents & Ligustrum \\
\hline L10091001 & Lents & Ligustrum \\
\hline L10091001 & Lents & Ligustrum \\
\hline L10091001 & Lents & Ligustrum \\
\hline L10091001 & Lents & Acer \\
\hline L10091001 & Lents & Prunus \\
\hline L10091001 & Lents & Prunus \\
\hline L10091001 & Lents & Prunus \\
\hline L10091001 & Lents & Syringa \\
\hline L10091001 & Lents & Hydrangea \\
\hline
\end{tabular}




\begin{tabular}{|c|c|c|}
\hline L10091001 & Lents & Hydrangea \\
\hline L10091001 & Lents & Nandina \\
\hline L10091001 & Lents & Nandina \\
\hline L10091001 & Lents & Nandina \\
\hline L10091001 & Lents & Nandina \\
\hline L10091001 & Lents & Spirea \\
\hline L10091301 & Lents & Acer \\
\hline L10091301 & Lents & Acer \\
\hline L10091301 & Lents & Acer \\
\hline L10091301 & Lents & Acer \\
\hline L10091301 & Lents & Pseudotsuga \\
\hline L10091301 & Lents & Acer \\
\hline L10091301 & Lents & Pyrus \\
\hline L10091301 & Lents & Juniperus \\
\hline L10091301 & Lents & Acer \\
\hline L10091301 & Lents & Prunus \\
\hline L10091301 & Lents & Berberis \\
\hline L10091301 & Lents & Berberis \\
\hline L10091301 & Lents & Taxus \\
\hline L10091301 & Lents & Sciadopitys \\
\hline L10091301 & Lents & Acer \\
\hline L10091301 & Lents & Picea \\
\hline L10091301 & Lents & Picea \\
\hline L10091301 & Lents & Prunus \\
\hline L10091301 & Lents & Prunus \\
\hline L10091301 & Lents & Prunus \\
\hline L10091301 & Lents & Prunus \\
\hline L10091301 & Lents & Acer \\
\hline L10091301 & Lents & Fraxinus \\
\hline L10091301 & Lents & Acer \\
\hline L10091301 & Lents & Thuja \\
\hline L10091301 & Lents & Acer \\
\hline L10091301 & Lents & Juniperus \\
\hline L10091301 & Lents & Juniperus \\
\hline L10091302 & Lents & Malus \\
\hline L10091302 & Lents & Acer \\
\hline L10091302 & Lents & Cornus \\
\hline L10091302 & Lents & Malus \\
\hline L10091302 & Lents & Pyrus \\
\hline L10091302 & Lents & Abies \\
\hline L10091302 & Lents & Camellia \\
\hline L10091302 & Lents & Camellia \\
\hline L10091302 & Lents & Rosa \\
\hline L10091302 & Lents & Rosa \\
\hline L10091302 & Lents & ododenc \\
\hline
\end{tabular}




\begin{tabular}{|c|c|c|}
\hline L10091302 & Lents & Thuja \\
\hline L10091302 & Lents & Thuja \\
\hline L10091302 & Lents & Thuja \\
\hline L10091302 & Lents & Hydrangea \\
\hline L10091302 & Lents & Rosa \\
\hline L10091302 & Lents & Rosa \\
\hline L10091302 & Lents & Rosa \\
\hline L10091302 & Lents & Buxus \\
\hline L10091302 & Lents & Hibiscus \\
\hline L10091302 & Lents & Thuja \\
\hline L10091302 & Lents & Chamaecyparis \\
\hline L10091302 & Lents & Chamaecyparis \\
\hline L10091302 & Lents & Chamaecyparis \\
\hline L10091302 & Lents & Pinus \\
\hline L10091302 & Lents & Pinus \\
\hline L10091302 & Lents & Taxus \\
\hline L10091302 & Lents & Euonymous \\
\hline L10091302 & Lents & Rosa \\
\hline L10091302 & Lents & Rosa \\
\hline L10091302 & Lents & Rosa \\
\hline L10091302 & Lents & Acer \\
\hline L10091302 & Lents & Rosa \\
\hline L10091302 & Lents & Rosa \\
\hline L10091302 & Lents & Rhododendron \\
\hline L10091302 & Lents & Rosa \\
\hline L10091302 & Lents & Crataegus \\
\hline L10091302 & Lents & Rosa \\
\hline L10091302 & Lents & Rosa \\
\hline L10091303 & Lents & Prunus \\
\hline L10091303 & Lents & Prunus \\
\hline L10091303 & Lents & Prunus \\
\hline L10091303 & Lents & Pyrus \\
\hline L10091303 & Lents & Pyrus \\
\hline L10091303 & Lents & Thuja \\
\hline L10091303 & Lents & Rosmarinus \\
\hline L10091303 & Lents & Rosmarinus \\
\hline L10091303 & Lents & Hibiscus \\
\hline L10091303 & Lents & Acer \\
\hline L10091303 & Lents & Syringa \\
\hline L10091303 & Lents & Lavandula \\
\hline L10091303 & Lents & Euphorbia \\
\hline L10091303 & Lents & Salvia \\
\hline L10091303 & Lents & Rosa \\
\hline L10091303 & Lents & Rosa \\
\hline L10091303 & Lents & Rosa \\
\hline
\end{tabular}




\begin{tabular}{|c|c|c|}
\hline L10091303 & Lents & Vaccinium \\
\hline L10091303 & Lents & Rosa \\
\hline L10091303 & Lents & Hibiscus \\
\hline L10091303 & Lents & Rosa \\
\hline L10091303 & Lents & Rosmarinus \\
\hline L10091303 & Lents & Rosa \\
\hline L10091303 & Lents & Hibiscus \\
\hline L10091303 & Lents & Salvia \\
\hline L10091303 & Lents & Rosmarinus \\
\hline L10091303 & Lents & Lavandula \\
\hline L10091303 & Lents & Buxus \\
\hline L10091303 & Lents & Salvia \\
\hline L10091303 & Lents & Loropetalum \\
\hline L10091303 & Lents & Vaccinium \\
\hline L10091303 & Lents & Loropetalum \\
\hline L10091303 & Lents & Lavandula \\
\hline L10091303 & Lents & Forsythia \\
\hline L10091303 & Lents & Pseudotsuga \\
\hline L10091303 & Lents & Pinus \\
\hline L10091303 & Lents & Pinus \\
\hline L10091303 & Lents & Thuja \\
\hline L10091303 & Lents & Thuja \\
\hline L10091303 & Lents & Thuja \\
\hline L10091303 & Lents & Juglans \\
\hline L10091303 & Lents & Prunus \\
\hline L10091303 & Lents & Prunus \\
\hline L10091303 & Lents & Rosmarinus \\
\hline L10091303 & Lents & Salvia \\
\hline L10091401 & Lents & Quercus \\
\hline L10091401 & Lents & Abies \\
\hline L10091401 & Lents & Betula \\
\hline L10091401 & Lents & Betula \\
\hline L10091401 & Lents & Thuja \\
\hline L10091401 & Lents & Calocedrus \\
\hline L10091401 & Lents & Calocedrus \\
\hline L10091401 & Lents & Tilia \\
\hline L10091401 & Lents & Liriodendron \\
\hline L10091401 & Lents & Viburnum \\
\hline L10091401 & Lents & Viburnum \\
\hline L10091401 & Lents & Viburnum \\
\hline L10091401 & Lents & Arbutus \\
\hline L10091401 & Lents & Mahonia \\
\hline L10091401 & Lents & Mahonia \\
\hline L10091401 & Lents & Abelia \\
\hline L10091401 & Lents & Arbutus \\
\hline
\end{tabular}




\begin{tabular}{|c|c|c|}
\hline L10091402 & Lents & Sorbus \\
\hline L10091402 & Lents & Larix \\
\hline L10091402 & Lents & Ilex \\
\hline L10091402 & Lents & Ilex \\
\hline L10091402 & Lents & Ilex \\
\hline L10091402 & Lents & Weigela \\
\hline L10091402 & Lents & Spirea \\
\hline L10091402 & Lents & Forsythia \\
\hline L10091402 & Lents & Rosa \\
\hline L10091402 & Lents & Viburnum \\
\hline L10091402 & Lents & Syringa \\
\hline L10091402 & Lents & Thuja \\
\hline L10091402 & Lents & Ilex \\
\hline L10091402 & Lents & Spirea \\
\hline L10091402 & Lents & Acer \\
\hline L10091402 & Lents & Chamaecyparis \\
\hline L10091402 & Lents & Pinus \\
\hline L10091402 & Lents & Rosa \\
\hline L10091402 & Lents & Thuja \\
\hline L10091402 & Lents & Viburnum \\
\hline L10091402 & Lents & Cornus \\
\hline L10091402 & Lents & Syringa \\
\hline L10091402 & Lents & Pinus \\
\hline L10091402 & Lents & Mahonia \\
\hline L10091402 & Lents & Mahonia \\
\hline L10091402 & Lents & Pieris \\
\hline L10091402 & Lents & Spirea \\
\hline L10091402 & Lents & Cornus \\
\hline L10091402 & Lents & Cornus \\
\hline L10091402 & Lents & Sorbus \\
\hline L10091402 & Lents & Chamaecyparis \\
\hline L10091402 & Lents & Spirea \\
\hline L10091402 & Lents & Mahonia \\
\hline L10091402 & Lents & Ilex \\
\hline L10091402 & Lents & Magnolia \\
\hline L10091402 & Lents & Forsythia \\
\hline L10091402 & Lents & Cornus \\
\hline L10091402 & Lents & Mahonia \\
\hline L10091402 & Lents & Spirea \\
\hline L10091402 & Lents & Picea \\
\hline L10091402 & Lents & Vaccinium \\
\hline L10091402 & Lents & Vaccinium \\
\hline L10091402 & Lents & Mahonia \\
\hline L10091402 & Lents & Cotoneaster \\
\hline L10091402 & Lents & Mahonia \\
\hline
\end{tabular}




\begin{tabular}{|c|c|c|}
\hline L10091402 & Lents & Thuja \\
\hline L10091402 & Lents & Sarcococca \\
\hline L10091402 & Lents & Cornus \\
\hline L10091402 & Lents & Ilex \\
\hline L10091403 & Lents & Sorbus \\
\hline L10091403 & Lents & Abelia \\
\hline L10091403 & Lents & Juniperus \\
\hline L10091403 & Lents & Thuja \\
\hline L10091403 & Lents & Thuja \\
\hline L10091403 & Lents & Thuja \\
\hline L10091404 & Lents & Cotoneaster \\
\hline L10091404 & Lents & Rosa \\
\hline L10091404 & Lents & Tilia \\
\hline L10091404 & Lents & Tilia \\
\hline L10091404 & Lents & Tilia \\
\hline L10091404 & Lents & Cotoneaster \\
\hline L10091404 & Lents & Ilex \\
\hline L10091404 & Lents & Ilex \\
\hline L10091404 & Lents & Ilex \\
\hline L10091404 & Lents & Ilex \\
\hline L10091404 & Lents & Ilex \\
\hline L10091404 & Lents & Ilex \\
\hline L10091404 & Lents & Ilex \\
\hline L10091404 & Lents & Ilex \\
\hline L10091404 & Lents & Ilex \\
\hline L10091404 & Lents & Acer \\
\hline L10091404 & Lents & Juglans \\
\hline L10091404 & Lents & Acer \\
\hline L10091404 & Lents & Acer \\
\hline L10091404 & Lents & Acer \\
\hline L10091404 & Lents & Acer \\
\hline L10091701 & Lents & Tilia \\
\hline L10091701 & Lents & Tilia \\
\hline L10091701 & Lents & Tilia \\
\hline L10091701 & Lents & Tilia \\
\hline L10091701 & Lents & Cotoneaster \\
\hline L10091702 & Lents & Acer \\
\hline L10091702 & Lents & Acer \\
\hline L10091702 & Lents & Prunus \\
\hline L10091702 & Lents & Prunus \\
\hline L10091702 & Lents & Vaccinium \\
\hline L10091702 & Lents & Thuja \\
\hline L10091702 & Lents & Malus \\
\hline L10091702 & Lents & Prunus \\
\hline L10091702 & Lents & Prunus \\
\hline
\end{tabular}




\begin{tabular}{|c|c|c|}
\hline L10091702 & Lents & Sorbus \\
\hline L10091702 & Lents & Abies \\
\hline L10091702 & Lents & Pinus \\
\hline L10091702 & Lents & Pseudotsuga \\
\hline L10091702 & Lents & Prunus \\
\hline L10091702 & Lents & Prunus \\
\hline L10091702 & Lents & Prunus \\
\hline L10091702 & Lents & Rhododendron \\
\hline L10091702 & Lents & Symphoricarpos \\
\hline L10091702 & Lents & Rosa \\
\hline L10091702 & Lents & Rosa \\
\hline L10091702 & Lents & Vaccinium \\
\hline L10091702 & Lents & Juglans \\
\hline L10091703 & Lents & Crataegus \\
\hline L10091703 & Lents & Cornus \\
\hline L10091703 & Lents & Rhododendron \\
\hline L10091703 & Lents & Rhododendron \\
\hline L10091703 & Lents & Rhododendron \\
\hline L10091703 & Lents & Ilex \\
\hline L10091703 & Lents & Camellia \\
\hline L10091703 & Lents & Hydrangea \\
\hline L10091703 & Lents & Vaccinium \\
\hline L10091703 & Lents & Hydrangea \\
\hline L10091703 & Lents & Vaccinium \\
\hline L10091703 & Lents & Vaccinium \\
\hline L10091703 & Lents & Pinus \\
\hline L10091703 & Lents & Pinus \\
\hline L10091703 & Lents & Magnolia \\
\hline L10091703 & Lents & Rhododendron \\
\hline L10091703 & Lents & Rhododendron \\
\hline L10091703 & Lents & Rhododendron \\
\hline L10091703 & Lents & Abelia \\
\hline L10091703 & Lents & Abelia \\
\hline L10091704 & Lents & Prunus \\
\hline L10091704 & Lents & Magnolia \\
\hline L10091704 & Lents & Rhododendron \\
\hline L10091704 & Lents & Rhododendron \\
\hline L10091704 & Lents & Rosa \\
\hline L10091704 & Lents & Paeonia \\
\hline L10091704 & Lents & Prunus \\
\hline L10091704 & Lents & Juglans \\
\hline L10091704 & Lents & Catalpa \\
\hline L10091704 & Lents & Abelia \\
\hline L10091704 & Lents & Prunus \\
\hline L10091704 & Lents & Ulmus \\
\hline
\end{tabular}




\begin{tabular}{|c|c|c|}
\hline L10091704 & Lents & Rosa \\
\hline L10091704 & Lents & Rosa \\
\hline L10091704 & Lents & Rosa \\
\hline L10091704 & Lents & Rosa \\
\hline L10091704 & Lents & Ulmus \\
\hline L10091704 & Lents & Acer \\
\hline L10091704 & Lents & Acer \\
\hline L10091704 & Lents & Prunus \\
\hline L10091704 & Lents & Prunus \\
\hline L10091705 & Lents & Photinia \\
\hline L10091705 & Lents & Rhododendron \\
\hline L10091705 & Lents & Rhododendron \\
\hline L10091705 & Lents & Rhododendron \\
\hline L10091705 & Lents & Camellia \\
\hline L10091705 & Lents & Taxus \\
\hline L10091705 & Lents & Ilex \\
\hline L10091705 & Lents & Prunus \\
\hline L10091705 & Lents & Rhododendron \\
\hline L10092001 & Lents & Malus \\
\hline L10092001 & Lents & Malus \\
\hline L10092001 & Lents & Acer \\
\hline L10092001 & Lents & Rhododendron \\
\hline L10092001 & Lents & Rosa \\
\hline L10092001 & Lents & Rosa \\
\hline L10092001 & Lents & Syringa \\
\hline L10092001 & Lents & Lavandula \\
\hline L10092001 & Lents & Syringa \\
\hline L10092001 & Lents & Cornus \\
\hline L10092001 & Lents & Rosa \\
\hline L10092001 & Lents & Ilex \\
\hline L10092001 & Lents & Syringa \\
\hline L10092001 & Lents & Syringa \\
\hline L10092001 & Lents & Acer \\
\hline L10092001 & Lents & Acer \\
\hline L10092001 & Lents & Buddleja \\
\hline L10092001 & Lents & Populus \\
\hline L10092001 & Lents & Rhododendron \\
\hline L10092001 & Lents & Acer \\
\hline L10092001 & Lents & Acer \\
\hline L10092001 & Lents & Thuja \\
\hline L10092001 & Lents & Rosa \\
\hline L10092001 & Lents & Acer \\
\hline L10092001 & Lents & Juniperus \\
\hline L10092001 & Lents & Picea \\
\hline L10092001 & Lents & Picea \\
\hline
\end{tabular}




\begin{tabular}{|c|c|c|}
\hline L10092001 & Lents & Pseudotsuga \\
\hline L10092001 & Lents & Malus \\
\hline L10092001 & Lents & Malus \\
\hline L10092001 & Lents & Unknown 3 \\
\hline L10092002 & Lents & Paeonia \\
\hline L10092002 & Lents & Rosa \\
\hline L10092002 & Lents & Paeonia \\
\hline L10092002 & Lents & Acer \\
\hline L10092002 & Lents & Rosa \\
\hline L10092002 & Lents & Rosa \\
\hline L10092002 & Lents & Rosa \\
\hline L10092002 & Lents & Rosa \\
\hline L10092002 & Lents & Hydrangea \\
\hline L10092002 & Lents & Acuba \\
\hline L10092002 & Lents & Paeonia \\
\hline L10092002 & Lents & Prunus \\
\hline L10092002 & Lents & Prunus \\
\hline L10092002 & Lents & Prunus \\
\hline L10092002 & Lents & Prunus \\
\hline L10092002 & Lents & Prunus \\
\hline L10092002 & Lents & Prunus \\
\hline L10092002 & Lents & Thuja \\
\hline L10092002 & Lents & Nandina \\
\hline L10092002 & Lents & Cupressus \\
\hline L10092002 & Lents & Thuja \\
\hline L10092002 & Lents & Cupressus \\
\hline L10092002 & Lents & Paeonia \\
\hline L10092002 & Lents & Buxus \\
\hline L10092002 & Lents & Paeonia \\
\hline L10092002 & Lents & Unknown 3 \\
\hline L10092002 & Lents & Hydrangea \\
\hline L10092002 & Lents & Hydrangea \\
\hline L10092002 & Lents & Thuja \\
\hline L10092002 & Lents & Fuschia \\
\hline L10092002 & Lents & Hydrangea \\
\hline L10092002 & Lents & Cornus \\
\hline L10092002 & Lents & Acer \\
\hline L10092002 & Lents & Rhododendron \\
\hline L10092002 & Lents & Nandina \\
\hline L10092002 & Lents & Rhododendron \\
\hline L10092002 & Lents & Nandina \\
\hline L10092002 & Lents & Acer \\
\hline L10092002 & Lents & Euonymous \\
\hline L10092002 & Lents & Pseudotsuga \\
\hline L10092002 & Lents & Nandina \\
\hline
\end{tabular}




\begin{tabular}{|c|c|c|}
\hline L10092002 & Lents & Juniperus \\
\hline L10092002 & Lents & Picea \\
\hline L10092002 & Lents & Cornus \\
\hline L10092002 & Lents & Rhododendron \\
\hline L10092002 & Lents & Thuja \\
\hline L10092201 & Lents & Acer \\
\hline L10092201 & Lents & Pieris \\
\hline L10092201 & Lents & Pieris \\
\hline L10092201 & Lents & Acer \\
\hline L10092201 & Lents & Paeonia \\
\hline L10092201 & Lents & Prunus \\
\hline L10092201 & Lents & Acer \\
\hline L10092201 & Lents & Prunus \\
\hline L10092201 & Lents & Prunus \\
\hline L10092201 & Lents & Aralia \\
\hline L10092201 & Lents & Aralia \\
\hline L10092201 & Lents & Corylus \\
\hline L10092201 & Lents & Aralia \\
\hline L10092201 & Lents & Spirea \\
\hline L10092201 & Lents & Prunus \\
\hline L10092202 & Lents & Pseudotsuga \\
\hline L10092202 & Lents & Picea \\
\hline L10092202 & Lents & Buxus \\
\hline L10092202 & Lents & Thuja \\
\hline L10092202 & Lents & Acer \\
\hline L10092202 & Lents & Acer \\
\hline L10092202 & Lents & Spirea \\
\hline L10092202 & Lents & Rosa \\
\hline L10092202 & Lents & Rosa \\
\hline L10092202 & Lents & Rosa \\
\hline L10092202 & Lents & Hydrangea \\
\hline L10092202 & Lents & Juniperus \\
\hline L10092202 & Lents & Juglans \\
\hline L10092202 & Lents & Ailanthus \\
\hline L10092202 & Lents & Rhododendron \\
\hline L10092203 & Lents & Ailanthus \\
\hline L10092203 & Lents & Camellia \\
\hline L10092203 & Lents & Vitis \\
\hline L10092203 & Lents & Vitis \\
\hline L10092203 & Lents & Castanea \\
\hline L10092203 & Lents & Rosa \\
\hline L10092203 & Lents & Yисса \\
\hline L10092203 & Lents & Euphorbia \\
\hline L10092203 & Lents & Betula \\
\hline L10092203 & Lents & Calocedrus \\
\hline
\end{tabular}




\begin{tabular}{|c|c|c|}
\hline L10092203 & Lents & Rosa \\
\hline L10092203 & Lents & Rosa \\
\hline L10092203 & Lents & Rosa \\
\hline L10092203 & Lents & Rosa \\
\hline L10092203 & Lents & Rosa \\
\hline L10092203 & Lents & Rosa \\
\hline L10092203 & Lents & Rosmarinus \\
\hline L10092203 & Lents & Syringa \\
\hline L10092204 & Lents & Acer \\
\hline L10092204 & Lents & Quercus \\
\hline L10092204 & Lents & Quercus \\
\hline L10092204 & Lents & Quercus \\
\hline L10092204 & Lents & Acer \\
\hline L10092205 & Lents & Cydonia \\
\hline L10092205 & Lents & Quercus \\
\hline L10092205 & Lents & Acer \\
\hline L10092205 & Lents & Quercus \\
\hline L10092206 & Lents & Acer \\
\hline L10092206 & Lents & Rhododendron \\
\hline L10092206 & Lents & Camellia \\
\hline L10092206 & Lents & Syringa \\
\hline L10092206 & Lents & Unknown 1 \\
\hline L10092206 & Lents & Unknown 1 \\
\hline L10092206 & Lents & Acer \\
\hline L10112601 & Lents & Pyrus \\
\hline L10112601 & Lents & Acer \\
\hline L10112601 & Lents & Pyrus \\
\hline L10112601 & Lents & Pyrus \\
\hline L10112601 & Lents & Prunus \\
\hline L10112601 & Lents & Pseudotsuga \\
\hline L10112601 & Lents & Thuja \\
\hline L10112601 & Lents & Cupressus \\
\hline L10112601 & Lents & Unknown 2 \\
\hline L10112601 & Lents & Putus \\
\hline L10112601 & Lents & Cupressus \\
\hline L10112601 & Lents & Rhododendron \\
\hline L10112601 & Lents & Rhododendron \\
\hline L10112601 & Lents & Rhododendron \\
\hline L10112601 & Lents & Rhododendron \\
\hline L10112601 & Lents & Weigela \\
\hline L10112601 & Lents & Rosa \\
\hline L10112601 & Lents & Lagerstromia \\
\hline L10112601 & Lents & Rosa \\
\hline L10112601 & Lents & Juniperus \\
\hline L10112601 & Lents & Juniperus \\
\hline
\end{tabular}




\begin{tabular}{|c|c|c|}
\hline L10112601 & Lents & Rhododendron \\
\hline L10112601 & Lents & Mahonia \\
\hline L10112601 & Lents & Spirea \\
\hline L10112601 & Lents & Nandina \\
\hline L10112601 & Lents & Rhododendron \\
\hline L10112601 & Lents & Rhododendron \\
\hline L10112601 & Lents & Mahonia \\
\hline L10112601 & Lents & Nandina \\
\hline L10112601 & Lents & Nandina \\
\hline L10112601 & Lents & Mahonia \\
\hline L10112601 & Lents & Rosa \\
\hline L10112601 & Lents & Rhododendron \\
\hline L10112601 & Lents & Rhododendron \\
\hline L10112601 & Lents & Mahonia \\
\hline L10112601 & Lents & Rosa \\
\hline L10112601 & Lents & Mahonia \\
\hline L10112601 & Lents & Buxus \\
\hline L10112602 & Lents & Pyrus \\
\hline L10112602 & Lents & Pyrus \\
\hline L10112602 & Lents & Malus \\
\hline L10112602 & Lents & Abies \\
\hline L10112602 & Lents & Juniperus \\
\hline L10112602 & Lents & Abies \\
\hline L10112602 & Lents & Acer \\
\hline L10112602 & Lents & Pinus \\
\hline L10112602 & Lents & Abies \\
\hline L10112602 & Lents & Pinus \\
\hline L10112602 & Lents & Pyrus \\
\hline L10112602 & Lents & Pyrus \\
\hline L10112602 & Lents & Rosa \\
\hline L10112602 & Lents & Rosa \\
\hline L10112602 & Lents & Rosa \\
\hline L10112602 & Lents & Rosa \\
\hline L10112602 & Lents & Rosa \\
\hline L10112602 & Lents & Rosa \\
\hline L10112602 & Lents & Camellia \\
\hline L10112602 & Lents & Nandina \\
\hline L10112602 & Lents & Unknown 1 \\
\hline L10112602 & Lents & Unknown 1 \\
\hline L10112602 & Lents & Buddleja \\
\hline L10112602 & Lents & Unknown 3 \\
\hline L10112603 & Lents & Pyrus \\
\hline L10112603 & Lents & Pyrus \\
\hline L10112603 & Lents & Malus \\
\hline L10112603 & Lents & Abies \\
\hline
\end{tabular}




\begin{tabular}{|c|c|c|}
\hline L10112603 & Lents & Pyrus \\
\hline L10112603 & Lents & Pyrus \\
\hline L10112603 & Lents & Rosmarinus \\
\hline L10112603 & Lents & Rosa \\
\hline L10112603 & Lents & Pyracantha \\
\hline L10112603 & Lents & Juniperus \\
\hline L10112603 & Lents & Rosa \\
\hline L10112603 & Lents & Unknown 2 \\
\hline L10112603 & Lents & Rosa \\
\hline L10112603 & Lents & Rosa \\
\hline L10112604 & Lents & Acer \\
\hline L10112604 & Lents & Cornus \\
\hline L10112604 & Lents & Pinus \\
\hline L10112604 & Lents & Abies \\
\hline L10112604 & Lents & Acer \\
\hline L10112604 & Lents & Rosa \\
\hline L10112604 & Lents & Thuja \\
\hline L10112604 & Lents & Hydrangea \\
\hline L10112604 & Lents & Hydrangea \\
\hline L10112604 & Lents & Viburnum \\
\hline L10112604 & Lents & Wisteria \\
\hline L10112604 & Lents & Rosa \\
\hline L10112605 & Lents & Acer \\
\hline L10112605 & Lents & Crataegus \\
\hline L10112605 & Lents & Crataegus \\
\hline L10112605 & Lents & Ilex \\
\hline L10112605 & Lents & Cornus \\
\hline L10112605 & Lents & Pinus \\
\hline L10112605 & Lents & Thuja \\
\hline L10112605 & Lents & Acer \\
\hline L10112605 & Lents & Rosa \\
\hline L10112605 & Lents & Rosa \\
\hline L10112605 & Lents & Thuja \\
\hline L10112605 & Lents & Hydrangea \\
\hline L10112605 & Lents & Hydrangea \\
\hline L10112605 & Lents & Viburnum \\
\hline L10112605 & Lents & Wisteria \\
\hline L10112606 & Lents & Prunus \\
\hline L10112606 & Lents & Prunus \\
\hline L10112606 & Lents & Prunus \\
\hline L10112606 & Lents & Malus \\
\hline L10112606 & Lents & Prunus \\
\hline L10112606 & Lents & Prunus \\
\hline L10112606 & Lents & Calocedrus \\
\hline L10112606 & Lents & Juniperus \\
\hline
\end{tabular}




\begin{tabular}{|c|c|c|}
\hline L10112606 & Lents & Rosa \\
\hline L10112606 & Lents & Juniperus \\
\hline L10112606 & Lents & Rhododendron \\
\hline L10112606 & Lents & Rhododendron \\
\hline L10112606 & Lents & Lavandula \\
\hline L10112606 & Lents & Viburnum \\
\hline L10112606 & Lents & Viburnum \\
\hline L10112606 & Lents & Buxus \\
\hline L10112606 & Lents & Thuja \\
\hline L10112606 & Lents & Buxus \\
\hline L10112606 & Lents & Buxus \\
\hline L10112606 & Lents & Juglans \\
\hline L10112701 & Lents & Larix \\
\hline L10112701 & Lents & Thuja \\
\hline L10112701 & Lents & Syringa \\
\hline L10112701 & Lents & Acer \\
\hline L10112701 & Lents & Juglans \\
\hline L10112701 & Lents & Cotinus \\
\hline L10112701 & Lents & Pieris \\
\hline L10112701 & Lents & Rosa \\
\hline L10112701 & Lents & Syringa \\
\hline L10112701 & Lents & Berberis \\
\hline L10112701 & Lents & Unknown 1 \\
\hline L10112701 & Lents & Quercus \\
\hline L10112701 & Lents & Rosa \\
\hline L10112701 & Lents & Rosa \\
\hline L10112701 & Lents & Syringa \\
\hline L10112701 & Lents & Arbutus \\
\hline L10112702 & Lents & Picea \\
\hline L10112702 & Lents & Cupressus \\
\hline L10112702 & Lents & Buxus \\
\hline L10112702 & Lents & Unknown 1 \\
\hline L10112702 & Lents & Buxus \\
\hline L10112702 & Lents & Ilex \\
\hline L10112702 & Lents & Rosa \\
\hline L10112702 & Lents & Unknown 2 \\
\hline L10112702 & Lents & Unknown 3 \\
\hline L10112702 & Lents & Buxus \\
\hline L10112703 & Lents & Carpinus \\
\hline L10112703 & Lents & Carpinus \\
\hline L10112703 & Lents & Castanea \\
\hline L10112703 & Lents & Cornus \\
\hline L10112703 & Lents & Thuja \\
\hline L10112703 & Lents & Thuja \\
\hline L10112703 & Lents & Prunus \\
\hline
\end{tabular}




\begin{tabular}{|c|c|c|}
\hline L10112703 & Lents & Buxus \\
\hline L10112703 & Lents & Syringa \\
\hline L10112703 & Lents & Rosa \\
\hline L10112703 & Lents & Rosa \\
\hline L10112703 & Lents & Rhododendron \\
\hline L10112703 & Lents & Rosa \\
\hline L10112703 & Lents & Ginkgo \\
\hline L10112703 & Lents & Prunus \\
\hline L10112703 & Lents & Rosa \\
\hline L10112703 & Lents & Rhododendron \\
\hline L10112703 & Lents & Rosa \\
\hline L10112703 & Lents & Rhododendron \\
\hline L10112703 & Lents & Rhododendron \\
\hline L10112703 & Lents & Rosa \\
\hline L10112703 & Lents & Rosa \\
\hline L10112703 & Lents & Rhododendron \\
\hline L10112704 & Lents & Betula \\
\hline L10112704 & Lents & Betula \\
\hline L10112704 & Lents & Betula \\
\hline L10112704 & Lents & Betula \\
\hline L10112704 & Lents & Betula \\
\hline L10112704 & Lents & Betula \\
\hline L10112704 & Lents & Betula \\
\hline L10112704 & Lents & Betula \\
\hline L10112704 & Lents & Betula \\
\hline L10112704 & Lents & Betula \\
\hline L10112704 & Lents & Betula \\
\hline L10112704 & Lents & Betula \\
\hline L10112704 & Lents & Crataegus \\
\hline L10112704 & Lents & Betula \\
\hline L10112704 & Lents & Betula \\
\hline L10112704 & Lents & Betula \\
\hline L10112704 & Lents & Betula \\
\hline L10112704 & Lents & Betula \\
\hline L10112704 & Lents & Betula \\
\hline L10112704 & Lents & Betula \\
\hline L10112704 & Lents & Betula \\
\hline L10112704 & Lents & Crataegus \\
\hline L10112704 & Lents & Betula \\
\hline L10112704 & Lents & Crataegus \\
\hline L10112704 & Lents & Crataegus \\
\hline L10112704 & Lents & Crataegus \\
\hline L10112704 & Lents & Betula \\
\hline L10112704 & Lents & Betula \\
\hline L10112704 & Lents & Betula \\
\hline
\end{tabular}




\begin{tabular}{|c|c|c|}
\hline L10112704 & Lents & Betula \\
\hline L10112704 & Lents & Betula \\
\hline L10112704 & Lents & Betula \\
\hline L10112704 & Lents & Betula \\
\hline L10112704 & Lents & Betula \\
\hline L10112704 & Lents & Betula \\
\hline L10112704 & Lents & Corylus \\
\hline L10112704 & Lents & Betula \\
\hline L10112704 & Lents & Crataegus \\
\hline L10112704 & Lents & Crataegus \\
\hline L10112704 & Lents & Crataegus \\
\hline L10112704 & Lents & Crataegus \\
\hline L10112704 & Lents & Betula \\
\hline L10112704 & Lents & Betula \\
\hline L10112704 & Lents & Corylus \\
\hline L10112704 & Lents & Betula \\
\hline L10112704 & Lents & Betula \\
\hline L10112704 & Lents & Crataegus \\
\hline L10112704 & Lents & Corylus \\
\hline L10112704 & Lents & Betula \\
\hline L10112704 & Lents & Betula \\
\hline L10112704 & Lents & Betula \\
\hline L10112704 & Lents & Betula \\
\hline L10112704 & Lents & Betula \\
\hline L10112704 & Lents & Crataegus \\
\hline L10112704 & Lents & Mahonia \\
\hline L10112704 & Lents & Symphoricarpos \\
\hline L10112704 & Lents & Crataegus \\
\hline L10112704 & Lents & Mahonia \\
\hline L10112704 & Lents & Symphoricarpos \\
\hline L10112704 & Lents & Mahonia \\
\hline L10112704 & Lents & Unknown 1 \\
\hline L10112704 & Lents & Unknown 1 \\
\hline L10112704 & Lents & Unknown 1 \\
\hline L10112704 & Lents & Acer \\
\hline L10112704 & Lents & Acer \\
\hline L10112704 & Lents & Acer \\
\hline L10112704 & Lents & Acer \\
\hline L10112704 & Lents & Unknown 2 \\
\hline L10112704 & Lents & Unknown 3 \\
\hline L10112704 & Lents & Crataegus \\
\hline L10112704 & Lents & Crataegus \\
\hline L10112704 & Lents & Crataegus \\
\hline L10112704 & Lents & Crataegus \\
\hline L10112704 & Lents & Crataegus \\
\hline
\end{tabular}




\begin{tabular}{|c|c|c|}
\hline L10112704 & Lents & Crataegus \\
\hline L10112704 & Lents & Cornus \\
\hline L10112704 & Lents & Crataegus \\
\hline L10112704 & Lents & Cornus \\
\hline L10112704 & Lents & Crataegus \\
\hline L10112704 & Lents & Crataegus \\
\hline L10112704 & Lents & Cornus \\
\hline L10112704 & Lents & Unknown 5 \\
\hline L10112704 & Lents & Cornus \\
\hline L10112704 & Lents & Crataegus \\
\hline L10112704 & Lents & Crataegus \\
\hline L10112704 & Lents & Cornus \\
\hline L10112901 & Lents & $N A$ \\
\hline L10112902 & Lents & Crataegus \\
\hline L10112902 & Lents & Crataegus \\
\hline L10112902 & Lents & Rhododendron \\
\hline L10112902 & Lents & Rosa \\
\hline L10112902 & Lents & Berberis \\
\hline L10112902 & Lents & Rhododendron \\
\hline L10112902 & Lents & Rosa \\
\hline L10112902 & Lents & Berberis \\
\hline L10112902 & Lents & Robinia \\
\hline L10112902 & Lents & Rosa \\
\hline L10112902 & Lents & Crataegus \\
\hline L10112902 & Lents & Magnolia \\
\hline L10113001 & Lents & Styrax \\
\hline L10113001 & Lents & Cupressus \\
\hline L10113001 & Lents & Malus \\
\hline L10113001 & Lents & Choisya \\
\hline L10113001 & Lents & Berberis \\
\hline L10113001 & Lents & Spirea \\
\hline L10113001 & Lents & Spirea \\
\hline L10113001 & Lents & Choisya \\
\hline L10113001 & Lents & Buxus \\
\hline L10113001 & Lents & Rosa \\
\hline L10113001 & Lents & Rosa \\
\hline L10113001 & Lents & Rosa \\
\hline L10113001 & Lents & Rosa \\
\hline L10113001 & Lents & Camellia \\
\hline L10113001 & Lents & Camellia \\
\hline L10113001 & Lents & Camellia \\
\hline L10113001 & Lents & Conifer \\
\hline L10113001 & Lents & Hydrangea \\
\hline L10113001 & Lents & Acuba \\
\hline L10113001 & Lents & Acuba \\
\hline
\end{tabular}




\begin{tabular}{|c|c|c|}
\hline L10113001 & Lents & Rhododendron \\
\hline L10113002 & Lents & Crataegus \\
\hline L10113002 & Lents & Sorbus \\
\hline L10113002 & Lents & Acer \\
\hline L10113002 & Lents & Camellia \\
\hline L10113002 & Lents & Rosa \\
\hline L10113002 & Lents & Rosa \\
\hline L10113002 & Lents & Pinus \\
\hline L10113002 & Lents & Acuba \\
\hline L10113002 & Lents & Prunus \\
\hline L10113002 & Lents & Ilex \\
\hline L10113003 & Lents & Abies \\
\hline L10113003 & Lents & Juniperus \\
\hline L10113003 & Lents & Rosa \\
\hline L10113003 & Lents & Rosa \\
\hline L10113003 & Lents & Juniperus \\
\hline L10113003 & Lents & Juniperus \\
\hline L10113003 & Lents & Juniperus \\
\hline L10113003 & Lents & Rosa \\
\hline L10113003 & Lents & Rhododendron \\
\hline L10113004 & Lents & Pseudotsuga \\
\hline L10113004 & Lents & Arbutus \\
\hline L10113004 & Lents & Malus \\
\hline L10113004 & Lents & Symphoricarpos \\
\hline L10113004 & Lents & Ilex \\
\hline L10113004 & Lents & Mahonia \\
\hline L10113004 & Lents & Rhododendron \\
\hline L10113004 & Lents & Arborvitae \\
\hline L10113004 & Lents & Rhododendron \\
\hline L10113004 & Lents & Rhododendron \\
\hline L10113004 & Lents & Acer \\
\hline L10113004 & Lents & Acer \\
\hline L10113005 & Lents & Prunus \\
\hline L10113005 & Lents & Cedrus \\
\hline L10113005 & Lents & Acer \\
\hline L10113005 & Lents & Acer \\
\hline L10113005 & Lents & Acer \\
\hline L10113005 & Lents & Acer \\
\hline L10113005 & Lents & Acer \\
\hline L10113005 & Lents & Photinia \\
\hline L10113005 & Lents & Unknown 1 \\
\hline L10113005 & Lents & Acer \\
\hline L10113005 & Lents & Acer \\
\hline L10113005 & Lents & Acer \\
\hline L10113005 & Lents & Acer \\
\hline
\end{tabular}




\begin{tabular}{|c|c|c|}
\hline L10113005 & Lents & Lavandula \\
\hline L10113005 & Lents & Viburnum \\
\hline L10113005 & Lents & Rosmarinus \\
\hline L10113005 & Lents & Rosmarinus \\
\hline L10113005 & Lents & Nandina \\
\hline L10113005 & Lents & Nandina \\
\hline L10113006 & Lents & Acer \\
\hline L10113006 & Lents & Acer \\
\hline L10113006 & Lents & Acer \\
\hline L10113006 & Lents & Prunus \\
\hline L10113006 & Lents & Acer \\
\hline L10113006 & Lents & Acer \\
\hline L10113006 & Lents & Rosa \\
\hline L10113006 & Lents & Acer \\
\hline L10113006 & Lents & Acer \\
\hline L10113006 & Lents & Acer \\
\hline L10113006 & Lents & Corylus \\
\hline L10113006 & Lents & Castanea \\
\hline L10113006 & Lents & Castanea \\
\hline L10113006 & Lents & Acer \\
\hline L10113006 & Lents & Acer \\
\hline L10113006 & Lents & Acer \\
\hline L10113006 & Lents & Acer \\
\hline L10113006 & Lents & Acer \\
\hline L10113006 & Lents & Acer \\
\hline L10113006 & Lents & Buxus \\
\hline L10113006 & Lents & Pieris \\
\hline L10113006 & Lents & Buddleja \\
\hline L10113006 & Lents & Buddleja \\
\hline L10113006 & Lents & Hypericum \\
\hline L10113006 & Lents & Salix \\
\hline L10113007 & Lents & Prunus \\
\hline L10113007 & Lents & Koelreuteria \\
\hline L10113007 & Lents & Acer \\
\hline L10113007 & Lents & Acer \\
\hline L10113007 & Lents & Catalpa \\
\hline L10113007 & Lents & Acer \\
\hline L10113007 & Lents & Koelreuteria \\
\hline L10113007 & Lents & Acer \\
\hline L10113007 & Lents & Buddleja \\
\hline L10113007 & Lents & Acer \\
\hline L10113007 & Lents & Acer \\
\hline L10113007 & Lents & Acer \\
\hline L10113007 & Lents & Acer \\
\hline L10113007 & Lents & Rosa \\
\hline
\end{tabular}




\begin{tabular}{|c|c|c|}
\hline L10113007 & Lents & Rosa \\
\hline L10113007 & Lents & Wisteria \\
\hline L10113007 & Lents & Rosa \\
\hline L10113007 & Lents & Rosa \\
\hline L10113008 & Lents & Acer \\
\hline L10113008 & Lents & Acer \\
\hline L10113008 & Lents & Acer \\
\hline L10113008 & Lents & Acer \\
\hline L10113008 & Lents & Acer \\
\hline L10113008 & Lents & Cornus \\
\hline L10113008 & Lents & Rosa \\
\hline L10113008 & Lents & Rosa \\
\hline L10113008 & Lents & Rosa \\
\hline L10113008 & Lents & Lavandula \\
\hline L10113008 & Lents & Rosa \\
\hline L10113008 & Lents & Rosa \\
\hline L10113009 & Lents & Unknown 1 \\
\hline L10113009 & Lents & Crataegus \\
\hline L10113009 & Lents & Salix \\
\hline L10113009 & Lents & Crataegus \\
\hline L10113009 & Lents & Crataegus \\
\hline L10113009 & Lents & Crataegus \\
\hline L10113009 & Lents & Salix \\
\hline L10113009 & Lents & Ash \\
\hline L10113009 & Lents & Acer \\
\hline L10113009 & Lents & Carpinus \\
\hline L10113009 & Lents & Alder \\
\hline L10113009 & Lents & Sorbus \\
\hline L10113009 & Lents & Alder \\
\hline L10113009 & Lents & Thuja \\
\hline L10113009 & Lents & Cedrus \\
\hline L10113009 & Lents & Unknown 2 \\
\hline L10113009 & Lents & Thuja \\
\hline L10113009 & Lents & Cedrus \\
\hline L10113009 & Lents & Unknown 2 \\
\hline L10113009 & Lents & Symphoricarpos \\
\hline L10113009 & Lents & Unknown 3 \\
\hline L10113010 & Lents & Sorbus \\
\hline L10113010 & Lents & Sorbus \\
\hline L10113010 & Lents & Sorbus \\
\hline L10113010 & Lents & Pseudotsuga \\
\hline L10113010 & Lents & Sorbus \\
\hline L10113010 & Lents & Sorbus \\
\hline L10113010 & Lents & Sorbus \\
\hline L10113010 & Lents & Unknown 1 \\
\hline
\end{tabular}




\begin{tabular}{|c|c|c|}
\hline L10113010 & Lents & Pseudotsuga \\
\hline L10113010 & Lents & Unknown 2 \\
\hline L10113010 & Lents & Pseudotsuga \\
\hline L10113010 & Lents & Pseudotsuga \\
\hline L10113010 & Lents & Pseudotsuga \\
\hline L10113010 & Lents & Crataegus \\
\hline L10113010 & Lents & Crataegus \\
\hline L10113010 & Lents & Alder \\
\hline L10113010 & Lents & Crataegus \\
\hline L10113010 & Lents & Crataegus \\
\hline L10113010 & Lents & Crataegus \\
\hline L10113010 & Lents & Crataegus \\
\hline L10113010 & Lents & Sorbus \\
\hline L10113010 & Lents & Sorbus \\
\hline L10113010 & Lents & Sorbus \\
\hline L10113010 & Lents & Alder \\
\hline L10113010 & Lents & Sorbus \\
\hline L10113010 & Lents & Sorbus \\
\hline L10113010 & Lents & Sorbus \\
\hline L10113010 & Lents & Alder \\
\hline L10113010 & Lents & Crataegus \\
\hline L10113010 & Lents & Sorbus \\
\hline L10113010 & Lents & Sorbus \\
\hline L10113010 & Lents & Pseudotsuga \\
\hline L10113010 & Lents & Pseudotsuga \\
\hline L10113010 & Lents & Mahonia \\
\hline L10120201 & Lents & Sorbus \\
\hline L10120201 & Lents & Sorbus \\
\hline L10120201 & Lents & Sorbus \\
\hline L10120201 & Lents & Sorbus \\
\hline L10120201 & Lents & Cercidiphyllum \\
\hline L10120201 & Lents & Cercidiphyllum \\
\hline L10120201 & Lents & Unknown 1 \\
\hline L10120201 & Lents & Unknown 1 \\
\hline L10120201 & Lents & Unknown 2 \\
\hline L10120201 & Lents & Crataegus \\
\hline L10120201 & Lents & Unknown 2 \\
\hline L10120201 & Lents & Unknown 2 \\
\hline L10120201 & Lents & Pyrus \\
\hline L10120201 & Lents & Pinus \\
\hline L10120201 & Lents & Picea \\
\hline L10120201 & Lents & Pinus \\
\hline L10120201 & Lents & Ilex \\
\hline L10120201 & Lents & Ilex \\
\hline L10120202 & Lents & Tsuga \\
\hline
\end{tabular}




\begin{tabular}{|c|c|c|}
\hline L10120202 & Lents & Tsuga \\
\hline L10120202 & Lents & Quercus \\
\hline L10120202 & Lents & Crataegus \\
\hline L10120202 & Lents & Crataegus \\
\hline L10120202 & Lents & Pseudotsuga \\
\hline L10120202 & Lents & Crataegus \\
\hline L10120202 & Lents & Pseudotsuga \\
\hline L10120202 & Lents & Pseudotsuga \\
\hline L10120202 & Lents & Tilia \\
\hline L10120202 & Lents & Crataegus \\
\hline L10120202 & Lents & Crataegus \\
\hline L10120202 & Lents & Mahonia \\
\hline L10120202 & Lents & Mahonia \\
\hline L10120202 & Lents & Mahonia \\
\hline L10120202 & Lents & Mahonia \\
\hline L10120202 & Lents & Mahonia \\
\hline L10120202 & Lents & Mahonia \\
\hline L10120202 & Lents & Mahonia \\
\hline L10120202 & Lents & Mahonia \\
\hline L10120202 & Lents & Mahonia \\
\hline L10120202 & Lents & Mahonia \\
\hline L10120202 & Lents & Mahonia \\
\hline L10120202 & Lents & Cytisus \\
\hline L10120202 & Lents & Cytisus \\
\hline L10120202 & Lloyd & Cytisus \\
\hline L10120202 & Lloyd & Cytisus \\
\hline L10120203 & Lloyd & Crataegus \\
\hline L10120203 & Lloyd & Crataegus \\
\hline L10120203 & Lloyd & Crataegus \\
\hline L10120203 & Lloyd & Crataegus \\
\hline L10120203 & Lloyd & Crataegus \\
\hline L10120203 & Lloyd & Crataegus \\
\hline L10120203 & Lloyd & Crataegus \\
\hline L10120203 & Lloyd & Crataegus \\
\hline L10120203 & Lloyd & Crataegus \\
\hline L10120203 & Lloyd & Crataegus \\
\hline L10120203 & Lloyd & Crataegus \\
\hline L10120203 & Lloyd & Crataegus \\
\hline L10120203 & Lloyd & Crataegus \\
\hline L10120203 & Lloyd & Crataegus \\
\hline L10120203 & Lloyd & Crataegus \\
\hline L10120203 & Lloyd & Crataegus \\
\hline L10120203 & Lloyd & Crataegus \\
\hline L10120203 & Lloyd & Crataegus \\
\hline L10120203 & Lloyd & Crataegus \\
\hline
\end{tabular}




\begin{tabular}{|c|c|c|}
\hline L10120203 & Lloyd & Corylus \\
\hline L10120203 & Lloyd & Corylus \\
\hline L10120203 & Lloyd & Ilex \\
\hline L10120203 & Lloyd & Lonicera \\
\hline L10120203 & Lloyd & Lonicera \\
\hline L10120203 & Lloyd & Lonicera \\
\hline L10120203 & Lloyd & Mahonia \\
\hline L10120203 & Lloyd & Mahonia \\
\hline L10120203 & Lloyd & Prunus \\
\hline L10120203 & Lloyd & Prunus \\
\hline L10120203 & Lloyd & Pseudotsuga \\
\hline L10120203 & Lloyd & Rosa \\
\hline L10120203 & Lloyd & Spirea \\
\hline L10120203 & Lloyd & Taxus \\
\hline L10120204 & Lloyd & Acer \\
\hline L10120204 & Lloyd & Acer \\
\hline L10120204 & Lloyd & Cytisus \\
\hline L10120204 & Lloyd & Cytisus \\
\hline L10120204 & Lloyd & Cytisus \\
\hline L10120204 & Lloyd & Polygonium \\
\hline L10120204 & Lloyd & Polygonium \\
\hline L10120204 & Lloyd & Taxus \\
\hline L10120204 & Lloyd & Taxus \\
\hline L10120204 & Lloyd & Taxus \\
\hline L110110501 & Lloyd & Carpinus \\
\hline L110110501 & Lloyd & Carpinus \\
\hline L110110501 & Lloyd & Carpinus \\
\hline L110110501 & Lloyd & Prunus \\
\hline L110110501 & Lloyd & Prunus \\
\hline L110110501 & Lloyd & Prunus \\
\hline L110110501 & Lloyd & Acer \\
\hline L110110501 & Lloyd & Acer \\
\hline L110110501 & Lloyd & Acer \\
\hline L110110501 & Lloyd & Spirea \\
\hline L110110501 & Lloyd & Cornus \\
\hline L110110501 & Lloyd & Cornus \\
\hline LL10110502 & Lloyd & Acer \\
\hline LL10110502 & Lloyd & Acer \\
\hline LL10110502 & Lloyd & Pinus \\
\hline LL10110502 & Lloyd & Pinus \\
\hline LL10110502 & Lloyd & Pinus \\
\hline LL10110502 & Lloyd & Acer \\
\hline LL10110502 & Lloyd & Acer \\
\hline LL10110502 & Lloyd & Photinia \\
\hline LL10110502 & Lloyd & Photinia \\
\hline
\end{tabular}




\begin{tabular}{|c|c|c|}
\hline LL10110502 & Lloyd & Photinia \\
\hline LL10110502 & Lloyd & Pinus \\
\hline LL10110502 & Lloyd & Pinus \\
\hline LL10110502 & Lloyd & Pinus \\
\hline LL10110502 & Lloyd & Pinus \\
\hline LL10110502 & Lloyd & Rhododendron \\
\hline LL10110502 & Lloyd & Rhododendron \\
\hline LL10110502 & Lloyd & Rhododendron \\
\hline LL10110502 & Lloyd & Rhododendron \\
\hline LL10110502 & Lloyd & Rhododendron \\
\hline LL10110502 & Lloyd & Rhododendron \\
\hline LL10110502 & Lloyd & Rhododendron \\
\hline LL10110502 & Lloyd & Rhododendron \\
\hline LL10110502 & Lloyd & Rhododendron \\
\hline LL10110502 & Lloyd & Rhododendron \\
\hline LL10110502 & Lloyd & Rhododendron \\
\hline LL10110502 & Lloyd & Rhododendron \\
\hline LL10110502 & Lloyd & Rhododendron \\
\hline LL10110502 & Lloyd & Rhododendron \\
\hline LL10110502 & Lloyd & Rhododendron \\
\hline LL10110502 & Lloyd & Rhododendron \\
\hline LL10110502 & Lloyd & Rhododendron \\
\hline LL10110502 & Lloyd & Rhododendron \\
\hline LL10110502 & Lloyd & Rhododendron \\
\hline LL10110502 & Lloyd & Rhododendron \\
\hline LL10110502 & Lloyd & Rhododendron \\
\hline LL10110502 & Lloyd & Rhododendron \\
\hline LL10110502 & Lloyd & Photinia \\
\hline LL10110502 & Lloyd & Photinia \\
\hline LL10110503 & Lloyd & Acer \\
\hline LL10110503 & Lloyd & Acer \\
\hline LL10110503 & Lloyd & Acer \\
\hline LL10110503 & Lloyd & Carpinus \\
\hline LL10110503 & Lloyd & Carpinus \\
\hline LL10110503 & Lloyd & Juniperus \\
\hline LL10110503 & Lloyd & Acer \\
\hline LL10110503 & Lloyd & Acer \\
\hline LL10110503 & Lloyd & Taxus \\
\hline LL10110503 & Lloyd & Taxus \\
\hline LL10110503 & Lloyd & Rhododendron \\
\hline LL10110503 & Lloyd & Ilex \\
\hline LL10110503 & Lloyd & Rhododendron \\
\hline LL10110503 & Lloyd & Rhododendron \\
\hline LL10110503 & Lloyd & Thuja \\
\hline LL10110503 & Lloyd & Acer \\
\hline
\end{tabular}




\begin{tabular}{|c|c|c|}
\hline LL10110504 & Lloyd & Platanus \\
\hline LL10110504 & Lloyd & Acer \\
\hline LL10110504 & Lloyd & Acer \\
\hline LL10110504 & Lloyd & Rosa \\
\hline LL10110504 & Lloyd & Camellia \\
\hline LL10110504 & Lloyd & Juniperus \\
\hline LL10110504 & Lloyd & Cedrus \\
\hline LL10110504 & Lloyd & Pseudotsuga \\
\hline LL10110504 & Lloyd & Unknown 1 \\
\hline LL10110505 & Lloyd & Quercus \\
\hline LL10110505 & Lloyd & Quercus \\
\hline LL10110505 & Lloyd & Tilia \\
\hline LL10110505 & Lloyd & Quercus \\
\hline LL10110505 & Lloyd & Viburnum \\
\hline LL10110505 & Lloyd & Viburnum \\
\hline LL10110505 & Lloyd & Viburnum \\
\hline LL10110505 & Lloyd & Viburnum \\
\hline LL10111201 & Lloyd & Abelia \\
\hline LL10111201 & Lloyd & Cotoneaster \\
\hline LL10111201 & Lloyd & Betula \\
\hline LL10111201 & Lloyd & Acer \\
\hline LL10111201 & Lloyd & Pseudotsuga \\
\hline LL10111201 & Lloyd & Picea \\
\hline LL10111201 & Lloyd & Abelia \\
\hline LL10111201 & Lloyd & Cotoneaster \\
\hline LL10111201 & Lloyd & Cotoneaster \\
\hline LL10111201 & Lloyd & Cotoneaster \\
\hline LL10111201 & Lloyd & Cotoneaster \\
\hline LL10111201 & Lloyd & Cotoneaster \\
\hline LL10111201 & Lloyd & Cotoneaster \\
\hline LL10111201 & Lloyd & Cotoneaster \\
\hline LL10111201 & Lloyd & Cotoneaster \\
\hline LL10111201 & Lloyd & Cotoneaster \\
\hline LL10111201 & Lloyd & Cotoneaster \\
\hline LL10111301 & Lloyd & Tilia \\
\hline LL10111301 & Lloyd & Tilia \\
\hline LL10111301 & Lloyd & Tilia \\
\hline LL10111301 & Lloyd & Pyrus \\
\hline LL10111301 & Lloyd & Dianthus \\
\hline LL10111301 & Lloyd & Dianthus \\
\hline LL10111301 & Lloyd & Dianthus \\
\hline LL10111301 & Lloyd & Dianthus \\
\hline LL10111301 & Lloyd & Dianthus \\
\hline LL10111301 & Lloyd & Dianthus \\
\hline LL10111301 & Lloyd & Berberis \\
\hline
\end{tabular}




\begin{tabular}{|c|c|c|}
\hline LL10111301 & Lloyd & Rhododendron \\
\hline LL10111301 & Lloyd & Arbutus \\
\hline LL10111301 & Lloyd & Ceanothus \\
\hline LL10111301 & Lloyd & Unknown 1 \\
\hline LL10111301 & Lloyd & Unknown 2 \\
\hline LL10111301 & Lloyd & Nandina \\
\hline LL10111301 & Lloyd & Nandina \\
\hline LL10111301 & Lloyd & Rosa \\
\hline LL10111301 & Lloyd & Nandina \\
\hline LL10111301 & Lloyd & Ilex \\
\hline LL10111301 & Lloyd & Nandina \\
\hline LL10111301 & Lloyd & Rhododendron \\
\hline LL10111301 & Lloyd & Rhododendron \\
\hline LL10111301 & Lloyd & Rhododendron \\
\hline LL10111301 & Lloyd & Weigela \\
\hline LL10111301 & Lloyd & Weigela \\
\hline LL10111301 & Lloyd & Weigela \\
\hline LL10111301 & Lloyd & Weigela \\
\hline LL10111301 & Lloyd & Weigela \\
\hline LL10111301 & Lloyd & Rosa \\
\hline LL10111302 & Lloyd & Acer \\
\hline LL10111302 & Lloyd & Acer \\
\hline LL10111302 & Lloyd & Acer \\
\hline LL10111302 & Lloyd & Acer \\
\hline LL10111302 & Lloyd & Dianthus \\
\hline LL10111302 & Lloyd & Dianthus \\
\hline LL10111302 & Lloyd & Dianthus \\
\hline LL10111302 & Lloyd & Dianthus \\
\hline LL10111302 & Lloyd & Dianthus \\
\hline LL10111302 & Lloyd & Dianthus \\
\hline LL10111302 & Lloyd & Juniperus \\
\hline LL10111302 & Lloyd & Betula \\
\hline LL10111302 & Lloyd & Juniperus \\
\hline LL10111302 & Lloyd & Nandina \\
\hline LL10111302 & Lloyd & Wisteria \\
\hline LL10111302 & Lloyd & Berberis \\
\hline LL10111302 & Lloyd & Berberis \\
\hline LL10111302 & Lloyd & Nandina \\
\hline LL10111302 & Lloyd & Pieris \\
\hline LL10111302 & Lloyd & Arbutus \\
\hline LL10111302 & Lloyd & Magnolia \\
\hline LL10111302 & Lloyd & Arbutus \\
\hline LL10111302 & Lloyd & Berberis \\
\hline LL10111302 & Lloyd & Fagus \\
\hline LL10111302 & Lloyd & Rosa \\
\hline
\end{tabular}




\begin{tabular}{|c|c|c|}
\hline LL10111302 & Lloyd & Weigela \\
\hline LL10111302 & Lloyd & Weigela \\
\hline LL10111302 & Lloyd & Weigela \\
\hline LL10111302 & Lloyd & Rosa \\
\hline LL10111302 & Lloyd & Weigela \\
\hline LL10111302 & Lloyd & Weigela \\
\hline LL10111302 & Lloyd & Weigela \\
\hline LL10111302 & Lloyd & Weigela \\
\hline LL10111302 & Lloyd & Weigela \\
\hline LL10111302 & Lloyd & Weigela \\
\hline LL10111302 & Lloyd & Weigela \\
\hline LL10111302 & Lloyd & Weigela \\
\hline LL10111302 & Lloyd & Weigela \\
\hline LL10111302 & Lloyd & Weigela \\
\hline LL10111302 & Lloyd & Weigela \\
\hline LL10111302 & Lloyd & Nandina \\
\hline LL10111302 & Lloyd & Nandina \\
\hline LL10111302 & Lloyd & Nandina \\
\hline LL10111302 & Lloyd & Rhododendron \\
\hline LL10111302 & Lloyd & Rhododendron \\
\hline LL10111302 & Lloyd & Rhododendron \\
\hline LL10111302 & Lloyd & Ilex \\
\hline LL10111302 & Lloyd & Rosa \\
\hline LL10111302 & Lloyd & Nandina \\
\hline LL10111302 & Lloyd & Nandina \\
\hline LL10111302 & Lloyd & Weigela \\
\hline LL10111302 & Lloyd & Weigela \\
\hline LL10111302 & Lloyd & Weigela \\
\hline LL10111302 & Lloyd & Weigela \\
\hline LL10111302 & Lloyd & Weigela \\
\hline LL10111601 & Lloyd & Acer \\
\hline LL10111601 & Lloyd & Acer \\
\hline LL10111601 & Lloyd & Acer \\
\hline LL10111601 & Lloyd & Acer \\
\hline LL10111601 & Lloyd & Rhododendron \\
\hline LL10111601 & Lloyd & Prunus \\
\hline LL10111601 & Lloyd & Prunus \\
\hline LL10111601 & Lloyd & Acer \\
\hline LL10111601 & Lloyd & Tilia \\
\hline LL10111601 & Lloyd & Rosa \\
\hline LL10111601 & Lloyd & Acer \\
\hline LL10111601 & Lloyd & Rhododendron \\
\hline LL10111602 & Lloyd & Carpinus \\
\hline LL10111602 & Lloyd & Carpinus \\
\hline LL10111602 & Lloyd & Carpinus \\
\hline
\end{tabular}




\begin{tabular}{|c|c|c|}
\hline LL10111602 & Lloyd & Pinus \\
\hline LL10111602 & Lloyd & Pinus \\
\hline LL10111602 & Lloyd & Pinus \\
\hline LL10111602 & Lloyd & Pinus \\
\hline LL10111602 & Lloyd & Pinus \\
\hline LL10111602 & Lloyd & Pinus \\
\hline LL10111602 & Lloyd & Pinus \\
\hline LL10111602 & Lloyd & Pinus \\
\hline LL10111602 & Lloyd & Pinus \\
\hline LL10111603 & Lloyd & Acer \\
\hline LL10111603 & Lloyd & Acer \\
\hline LL10111603 & Lloyd & Rhododendron \\
\hline LL10111603 & Lloyd & Rhododendron \\
\hline LL10111603 & Lloyd & Rhododendron \\
\hline LL10111603 & Lloyd & Rosa \\
\hline LL10111603 & Lloyd & Rosa \\
\hline LL10111604 & Lloyd & Populus \\
\hline LL10111604 & Lloyd & Nandina \\
\hline LL10111604 & Lloyd & Nandina \\
\hline LL10111604 & Lloyd & Nandina \\
\hline LL10111604 & Lloyd & Populus \\
\hline LL10111604 & Lloyd & Nandina \\
\hline LL10111604 & Lloyd & Nandina \\
\hline LL10111604 & Lloyd & Populus \\
\hline LL10111604 & Lloyd & Populus \\
\hline LL10111604 & Lloyd & Nandina \\
\hline LL10111604 & Lloyd & Nandina \\
\hline LL10111604 & Lloyd & Nandina \\
\hline LL10111604 & Lloyd & Populus \\
\hline LL10111604 & Lloyd & Carpinus \\
\hline LL10111604 & Lloyd & Carpinus \\
\hline LL10111604 & Lloyd & Populus \\
\hline LL10111604 & Lloyd & Populus \\
\hline LL10111604 & Lloyd & Nandina \\
\hline LL10111604 & Lloyd & Nandina \\
\hline LL10111604 & Lloyd & Nandina \\
\hline LL10111604 & Lloyd & Nandina \\
\hline LL10111604 & Lloyd & Nandina \\
\hline LL10111604 & Lloyd & Nandina \\
\hline LL10111604 & Lloyd & Nandina \\
\hline LL10111604 & Lloyd & Nandina \\
\hline LL10111604 & Lloyd & Nandina \\
\hline LL10112001 & Lloyd & Tilia \\
\hline LL10112001 & Lloyd & Tilia \\
\hline LL10112001 & Lloyd & Tilia \\
\hline
\end{tabular}




\begin{tabular}{|c|c|c|}
\hline LL10112001 & Lloyd & Tilia \\
\hline LL10112001 & Lloyd & Tilia \\
\hline LL10112001 & Lloyd & Tilia \\
\hline LL10112001 & Lloyd & Tilia \\
\hline LL10112001 & Lloyd & Tilia \\
\hline LL10112001 & Lloyd & Thuja \\
\hline LL10112001 & Lloyd & Thuja \\
\hline LL10112001 & Lloyd & Pieris \\
\hline LL10112001 & Lloyd & Tilia \\
\hline LL10112001 & Lloyd & Euonymous \\
\hline LL10112001 & Lloyd & Euonymous \\
\hline LL10112001 & Lloyd & Euonymous \\
\hline LL10112001 & Lloyd & Euonymous \\
\hline LL10112001 & Lloyd & Euonymous \\
\hline LL10112001 & Lloyd & Euonymous \\
\hline LL10112002 & Lloyd & Tilia \\
\hline LL10112002 & Lloyd & Tilia \\
\hline LL10112002 & Lloyd & Tilia \\
\hline LL10112002 & Lloyd & Acer \\
\hline LL10112002 & Lloyd & Tilia \\
\hline LL10112002 & Lloyd & Acer \\
\hline LL10112002 & Lloyd & Tilia \\
\hline LL10112002 & Lloyd & Tilia \\
\hline LL10112002 & Lloyd & Tilia \\
\hline LL10112002 & Lloyd & Tilia \\
\hline LL10112002 & Lloyd & Tilia \\
\hline LL10112002 & Lloyd & Thuja \\
\hline LL10112002 & Lloyd & Thuja \\
\hline LL10112002 & Lloyd & Euonymous \\
\hline LL10112002 & Lloyd & Euonymous \\
\hline LL10112002 & Lloyd & Euonymous \\
\hline LL10112003 & Lloyd & Pinus \\
\hline LL10112003 & Lloyd & Acer \\
\hline LL10112003 & Lloyd & Acer \\
\hline LL10112003 & Lloyd & Acer \\
\hline LL10112003 & Lloyd & Acer \\
\hline LL10112003 & Lloyd & Acer \\
\hline LL10112003 & Lloyd & Acer \\
\hline LL10112003 & Lloyd & Tilia \\
\hline LL10112003 & Lloyd & Tilia \\
\hline LL10112003 & Lloyd & Quercus \\
\hline LL10112003 & Lloyd & Pieris \\
\hline LL10112003 & Lloyd & Mahonia \\
\hline LL10112003 & Lloyd & Gaultheria \\
\hline LL10112003 & Lloyd & Quercus \\
\hline
\end{tabular}




\begin{tabular}{|c|c|c|}
\hline LL10112003 & Lloyd & Pieris \\
\hline LL10112003 & Lloyd & Mahonia \\
\hline LL10112003 & Lloyd & Gaultheria \\
\hline LL10112003 & Lloyd & Acer \\
\hline LL10112003 & Lloyd & Tilia \\
\hline LL10112003 & Lloyd & Thuja \\
\hline LL10112004 & Lloyd & Crataegus \\
\hline LL10112004 & Lloyd & Crataegus \\
\hline LL10112004 & Lloyd & Tilia \\
\hline LL10112004 & Lloyd & Tilia \\
\hline LL10112004 & Lloyd & Tilia \\
\hline LL10112004 & Lloyd & Crataegus \\
\hline LL10112004 & Lloyd & Crataegus \\
\hline LL10112004 & Lloyd & Unknown 1 \\
\hline LL10112004 & Lloyd & Rhododendron \\
\hline LL10112004 & Lloyd & Rhododendron \\
\hline LL10112004 & Lloyd & Berberis \\
\hline LL10112004 & Lloyd & Berberis \\
\hline LL10112004 & Lloyd & Berberis \\
\hline LL10112004 & Lloyd & Berberis \\
\hline LL10112004 & Lloyd & Ligustrum \\
\hline LL10112004 & Lloyd & Ligustrum \\
\hline LL10112004 & Lloyd & Viburnum \\
\hline LL10112004 & Lloyd & Rhododendron \\
\hline LL10112004 & Lloyd & Berberis \\
\hline LL10112004 & Lloyd & Berberis \\
\hline LL10112004 & Lloyd & Berberis \\
\hline LL10112004 & Lloyd & Berberis \\
\hline LL10112004 & Lloyd & Berberis \\
\hline LL10112004 & Lloyd & Rhododendron \\
\hline LL10112004 & Lloyd & Rhododendron \\
\hline LL10112004 & Lloyd & Cotoneaster \\
\hline LL10112004 & Lloyd & Cotoneaster \\
\hline LL10112005 & Lloyd & Platanus \\
\hline LL10112005 & Lloyd & Platanus \\
\hline LL10112006 & Lloyd & Pyrus \\
\hline LL10112006 & Lloyd & Platanus \\
\hline LL10112006 & Lloyd & Platanus \\
\hline LL10112006 & Lloyd & Platanus \\
\hline LL10112006 & Lloyd & Pyrus \\
\hline LL10112007 & Lloyd & Liquidambar \\
\hline LL10112007 & Lloyd & Liquidambar \\
\hline LL10112007 & Lloyd & Liquidambar \\
\hline LL10112007 & Lloyd & Styrax \\
\hline LL10112007 & Lloyd & Styrax \\
\hline
\end{tabular}




\begin{tabular}{|c|c|c|}
\hline LL10112007 & Lloyd & Euonymous \\
\hline LL10112007 & Lloyd & Euonymous \\
\hline LL10112007 & Lloyd & Euonymous \\
\hline LL10112007 & Lloyd & Euonymous \\
\hline LL10112007 & Lloyd & Euonymous \\
\hline LL10112007 & Lloyd & Euonymous \\
\hline LL10112007 & Lloyd & Euonymous \\
\hline LL10112008 & Lloyd & Gleditsia \\
\hline LL10112008 & Lloyd & Gleditsia \\
\hline LL10112008 & Lloyd & Gleditsia \\
\hline LL10112008 & Lloyd & Acer \\
\hline LL10112008 & Lloyd & Acer \\
\hline LL10112008 & Lloyd & Pinus \\
\hline LL10112008 & Lloyd & Fraxinus \\
\hline LL10112008 & Lloyd & Thuja \\
\hline LL10112008 & Lloyd & Thuja \\
\hline LL10112008 & Lloyd & Thuja \\
\hline LL10112008 & Lloyd & Thuja \\
\hline LL10112008 & Lloyd & Thuja \\
\hline LL10112008 & Lloyd & Thuja \\
\hline LL10112008 & Lloyd & Thuja \\
\hline LL10112008 & Lloyd & Thuja \\
\hline LL10112008 & Lloyd & Thuja \\
\hline LL10112101 & Lloyd & $N A$ \\
\hline LL10112102 & Lloyd & $N A$ \\
\hline LL10112103 & Lloyd & Platanus \\
\hline LL10112103 & Lloyd & Platanus \\
\hline LL10112103 & Lloyd & Platanus \\
\hline LL10112103 & Lloyd & Platanus \\
\hline LL10112103 & Lloyd & Populus \\
\hline LL10112104 & Lloyd & Tilia \\
\hline LL10112104 & Lloyd & Tilia \\
\hline LL10112104 & Lloyd & Tilia \\
\hline LL10112104 & Lloyd & Tilia \\
\hline LL10112104 & Lloyd & Liriodendron \\
\hline LL10112104 & Lloyd & Tilia \\
\hline LL10112104 & Lloyd & Tilia \\
\hline LL10112104 & Lloyd & Acer \\
\hline LL10112104 & Lloyd & Unknown 1 \\
\hline LL10112104 & Lloyd & Cornus \\
\hline LL10112104 & Lloyd & Magnolia \\
\hline LL10112104 & Lloyd & Magnolia \\
\hline LL10112104 & Lloyd & Pieris \\
\hline LL10112104 & Lloyd & Acer \\
\hline LL10112104 & Lloyd & Unknown 2 \\
\hline
\end{tabular}




\begin{tabular}{|c|c|c|}
\hline LL10112104 & Lloyd & Berberis \\
\hline LL10112104 & Lloyd & Berberis \\
\hline LL10112104 & Lloyd & Berberis \\
\hline LL10112104 & Lloyd & Berberis \\
\hline LL10112104 & Lloyd & Ligustrum \\
\hline LL10112105 & Lloyd & Platanus \\
\hline LL10112105 & Lloyd & Platanus \\
\hline LL10112105 & Lloyd & Platanus \\
\hline LL10112106 & Lloyd & Acer \\
\hline LL10112106 & Lloyd & Acer \\
\hline LL10112106 & Lloyd & Taxus \\
\hline LL10112106 & Lloyd & Buxus \\
\hline LL10112106 & Lloyd & Ilex \\
\hline LL10112106 & Lloyd & Buxus \\
\hline LL10112106 & Lloyd & Taxus \\
\hline LL10112106 & Lloyd & Buxus \\
\hline LL10112107 & Lloyd & Acer \\
\hline LL10112107 & Lloyd & Acer \\
\hline LL10112107 & Lloyd & Acer \\
\hline LL10112107 & Lloyd & Acer \\
\hline LL10112107 & Lloyd & Euonymous \\
\hline LL10112107 & Lloyd & Berberis \\
\hline LL10112107 & Lloyd & Cotoneaster \\
\hline LL10112107 & Lloyd & Euonymous \\
\hline LL10112107 & Lloyd & Berberis \\
\hline LL10112107 & Lloyd & Cotoneaster \\
\hline LL10112108 & Lloyd & Euonymous \\
\hline LL10112108 & Lloyd & Berberis \\
\hline LL10112108 & Lloyd & Acer \\
\hline LL10112108 & Lloyd & Acer \\
\hline LL10112108 & Lloyd & Acer \\
\hline LL10112108 & Lloyd & Acer \\
\hline LL10112109 & Lloyd & Malus \\
\hline LL10112109 & Lloyd & Malus \\
\hline LL10112109 & Lloyd & Malus \\
\hline LL10112109 & Lloyd & Cedrus \\
\hline LL10112109 & Lloyd & Buxus \\
\hline LL10112109 & Lloyd & Quercus \\
\hline LL10112109 & Lloyd & Quercus \\
\hline LL10112109 & Lloyd & Quercus \\
\hline LL10112109 & Lloyd & Quercus \\
\hline LL10112109 & Lloyd & Acer \\
\hline LL10112109 & Lloyd & Buxus \\
\hline LL10112301 & Lloyd & Abies \\
\hline LL10112301 & Lloyd & Abies \\
\hline
\end{tabular}




\begin{tabular}{|c|c|c|}
\hline LL10112301 & Lloyd & Abies \\
\hline LL10112301 & Lloyd & Abies \\
\hline LL10112301 & Lloyd & Abies \\
\hline LL10112301 & Lloyd & Pinus \\
\hline LL10112301 & Lloyd & Pinus \\
\hline LL10112301 & Lloyd & Pinus \\
\hline LL10112301 & Lloyd & Pinus \\
\hline LL10112301 & Lloyd & Abies \\
\hline LL10112302 & Lloyd & Unknown 1 \\
\hline LL10112303 & Lloyd & Populus \\
\hline LL10112303 & Lloyd & Populus \\
\hline LL10112304 & Lloyd & Cedrus \\
\hline LL10112304 & Lloyd & Prunus \\
\hline LL10112304 & Lloyd & Quercus \\
\hline LL10112304 & Lloyd & Populus \\
\hline LL10112304 & Lloyd & Acer \\
\hline LL10112304 & Lloyd & Populus \\
\hline LL10112304 & Lloyd & Populus \\
\hline LL10112304 & Lloyd & Prunus \\
\hline LL10112304 & Lloyd & Pseudotsuga \\
\hline LL10112304 & Lloyd & Prunus \\
\hline LL10112304 & Lloyd & Prunus \\
\hline LL10112304 & Lloyd & Quercus \\
\hline LL10112304 & Lloyd & Populus \\
\hline LL10112304 & Lloyd & Prunus \\
\hline LL10112305 & Lloyd & Acer \\
\hline LL10112305 & Lloyd & Acer \\
\hline LL10112305 & Lloyd & Acer \\
\hline LL10112305 & Lloyd & Acer \\
\hline LL10112305 & Lloyd & Ilex \\
\hline LL10112305 & Lloyd & Ilex \\
\hline LL10112305 & Lloyd & Ilex \\
\hline LL10112305 & Lloyd & Ilex \\
\hline LL10112305 & Lloyd & Ilex \\
\hline LL10112305 & Lloyd & Ilex \\
\hline
\end{tabular}


Appendix B. Coordinates of Each Site. Decimal Degrees, GCS NAD 1983.

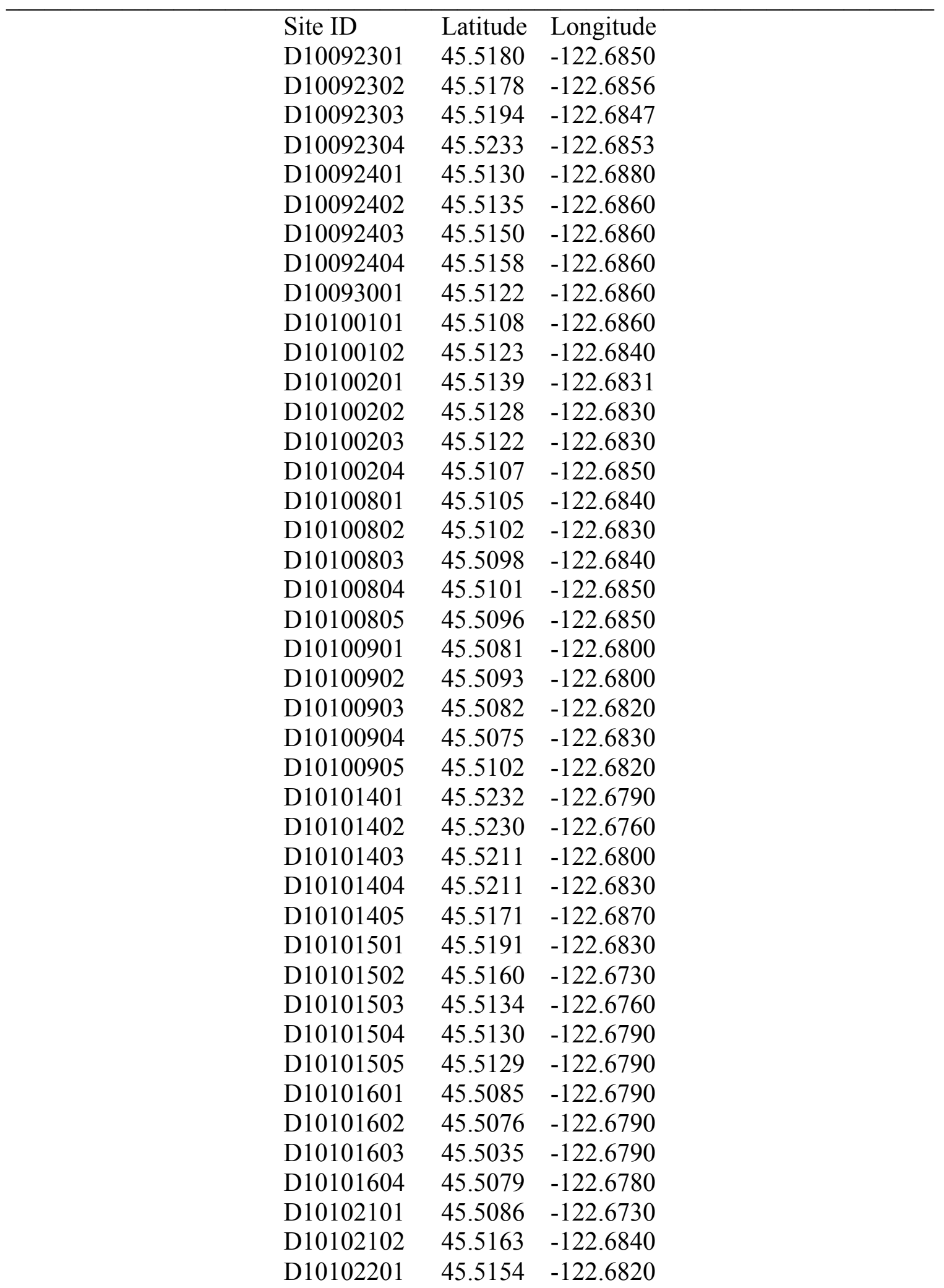




$\begin{array}{lll}\text { D10102202 } & 45.5091 & -122.6730 \\ \text { D10102203 } & 45.5097 & -122.6750 \\ \text { D10102204 } & 45.5083 & -122.6750 \\ \text { D10102205 } & 45.5081 & -122.6750 \\ \text { D10102206 } & 45.5072 & -122.6760 \\ \text { D10102207 } & 45.5071 & -122.6760 \\ \text { G10082601 } & 45.5133 & -122.5660 \\ \text { G10082602 } & 45.5132 & -122.5660 \\ \text { G10082701 } & 45.5125 & -122.5640 \\ \text { G10082702 } & 45.5132 & -122.5640 \\ \text { G10082703 } & 45.5112 & -122.5610 \\ \text { G10082704 } & 45.5117 & -122.5610 \\ \text { G10083001 } & 45.5139 & -122.5560 \\ \text { G10083002 } & 45.5169 & -122.5540 \\ \text { G10083003 } & 45.5191 & -122.5510 \\ \text { G10083004 } & 45.5196 & -122.5540 \\ \text { G10083101 } & 45.5210 & -122.5590 \\ \text { G10090201 } & 45.5225 & -122.5560 \\ \text { G10090202 } & 45.5281 & -122.5580 \\ \text { G10090301 } & 45.5159 & -122.5640 \\ \text { G10090302 } & 45.5262 & -122.5670 \\ \text { G10090303 } & 45.5276 & -122.5620 \\ \text { G10090304 } & 45.5341 & -122.5590 \\ \text { G10090601 } & 45.5308 & -122.5560 \\ \text { G10090602 } & 45.5345 & -122.5520 \\ \text { L10090701 } & 45.4937 & -122.5670 \\ \text { L10090702 } & 45.4949 & -122.5670 \\ \text { L10090703 } & 45.4967 & -122.5720 \\ \text { L10090901 } & 45.4918 & -122.5690 \\ \text { L10090902 } & 45.4908 & -122.5670 \\ \text { L10090903 } & 45.4857 & -122.5690 \\ \text { L10090904 } & 45.4851 & -122.5690 \\ \text { L10091001 } & 45.4892 & -122.5720 \\ \text { L10091301 } & 45.4846 & -122.5710 \\ \text { L10091302 } & 45.4834 & -122.5570 \\ \text { L10091303 } & 45.4841 & -122.5560 \\ \text { L10091401 } & 45.4960 & -122.5610 \\ \text { L10091402 } & 45.4953 & -122.5560 \\ \text { L10091403 } & 45.4949 & -122.5540 \\ \text { L10091404 } & 45.4949 & -122.5490 \\ \text { L10091701 } & 45.4949 & -122.5500 \\ \text { L10091702 } & 45.4933 & -122.5560 \\ \text { L10091704 } & 45.4925 & -122.5530 \\ \text { L10091705 } & 45.4933 & -122.5530 \\ \text { L10092001 } & 45.4925 & -122.5570 \\ & & \end{array}$




$\begin{array}{lll}\text { L10092002 } & 45.4916 & -122.5480 \\ \text { L10092201 } & 45.4915 & -122.5540 \\ \text { L10092202 } & 45.4916 & -122.5570 \\ \text { L10092203 } & 45.4871 & -122.5510 \\ \text { L10092204 } & 45.4849 & -122.5560 \\ \text { L10092205 } & 45.4849 & -122.5590 \\ \text { L10092206 } & 45.4853 & -122.5590 \\ \text { L10112601 } & 45.4814 & -122.5700 \\ \text { L10112602 } & 45.4769 & -122.5690 \\ \text { L10112603 } & 45.4767 & -122.5690 \\ \text { L10112604 } & 45.4759 & -122.5750 \\ \text { L10112605 } & 45.4759 & -122.5740 \\ \text { L10112606 } & 45.4756 & -122.5760 \\ \text { L10112701 } & 45.4749 & -122.5710 \\ \text { L10112702 } & 45.4706 & -122.5780 \\ \text { L10112703 } & 45.4716 & -122.5750 \\ \text { L10112704 } & 45.4692 & -122.5710 \\ \text { L10112901 } & 45.4791 & -122.5660 \\ \text { L10112902 } & 45.4748 & -122.5670 \\ \text { L10113001 } & 45.4789 & -122.5630 \\ \text { L10113002 } & 45.4821 & -122.5640 \\ \text { L10113003 } & 45.4806 & -122.5620 \\ \text { L10113004 } & 45.4796 & -122.5600 \\ \text { L10113005 } & 45.4811 & -122.5570 \\ \text { L10113006 } & 45.4805 & -122.5560 \\ \text { L10113007 } & 45.4799 & -122.5560 \\ \text { L10113008 } & 45.4796 & -122.5560 \\ \text { L10113009 } & 45.4779 & -122.5490 \\ \text { L10113010 } & 45.4741 & -122.5480 \\ \text { L10120201 } & 45.4683 & -122.5510 \\ \text { L10120202 } & 45.4685 & -122.5670 \\ \text { L10120203 } & 45.4662 & -122.5760 \\ \text { L10120204 } & 45.4739 & -122.5630 \\ \text { LL10110501 } & 45.5268 & -122.6620 \\ \text { LL10110502 } & 45.5330 & -122.6610 \\ \text { LL10110503 } & 45.5330 & -122.6620 \\ \text { LL10110504 } & 45.5338 & -122.6600 \\ \text { LL10110505 } & 45.5322 & -122.6630 \\ \text { LL10111201 } & 45.5315 & -122.6650 \\ \text { LL10111301 } & 45.5318 & -122.6490 \\ \text { LL10111302 } & 45.5316 & -122.6490 \\ \text { LL10111601 } & 45.5330 & -122.6690 \\ \text { LL10111602 } & 45.5328 & -122.6700 \\ \text { LL10111603 } & 45.5330 & -122.6680 \\ \text { LL10111604 } & 45.5343 & -122.6680\end{array}$




$\begin{array}{lll}\text { LL10112001 } & 45.5322 & -122.6500 \\ \text { LL10112002 } & 45.5330 & -122.6500 \\ \text { LL10112003 } & 45.5327 & -122.6500 \\ \text { LL10112004 } & 45.5310 & -122.6490 \\ \text { LL10112005 } & 45.5313 & -122.6520 \\ \text { LL10112006 } & 45.5304 & -122.6520 \\ \text { LL10112007 } & 45.5301 & -122.6540 \\ \text { LL10112008 } & 45.5303 & -122.6570 \\ \text { LL10112101 } & 45.5304 & -122.6580 \\ \text { LL10112102 } & 45.5304 & -122.6580 \\ \text { LL10112103 } & 45.5284 & -122.6560 \\ \text { LL10112104 } & 45.5287 & -122.6570 \\ \text { LL10112105 } & 45.5289 & -122.6555 \\ \text { LL10112106 } & 45.5305 & -122.6640 \\ \text { LL10112107 } & 45.5302 & -122.6640 \\ \text { LL10112108 } & 45.5301 & -122.6630 \\ \text { LL10112109 } & 45.5323 & -122.6710 \\ \text { LL10112301 } & 45.5294 & -122.6660 \\ \text { LL10112302 } & 45.5292 & -122.6670 \\ \text { LL10112303 } & 45.5326 & -122.6710 \\ \text { LL10112304 } & 45.5299 & -122.6690 \\ \text { LL10112305 } & 45.5313 & -122.6690\end{array}$

